\title{
Identifying the type and appropriateness of the evaluations of selected agriculturally related science and technology-based USAID projects conducted between 1985 and 1995
}

\author{
Allen E. Bayles \\ West Virginia University
}

Follow this and additional works at: https://researchrepository.wvu.edu/etd

\section{Recommended Citation}

Bayles, Allen E., "Identifying the type and appropriateness of the evaluations of selected agriculturally related science and technology-based USAID projects conducted between 1985 and 1995" (1998). Graduate Theses, Dissertations, and Problem Reports. 3117.

https://researchrepository.wvu.edu/etd/3117

This Dissertation is protected by copyright and/or related rights. It has been brought to you by the The Research Repository @ WVU with permission from the rights-holder(s). You are free to use this Dissertation in any way that is permitted by the copyright and related rights legislation that applies to your use. For other uses you must obtain permission from the rights-holder(s) directly, unless additional rights are indicated by a Creative Commons license in the record and/ or on the work itself. This Dissertation has been accepted for inclusion in WVU Graduate Theses, Dissertations, and Problem Reports collection by an authorized administrator of The Research Repository @ WVU.

For more information, please contact researchrepository@mail.wvu.edu. 


\section{IDENTIFYING THE TYPE AND APPROPRIATENESS OF THE \\ EVALUATIONS OF SELECTED AGRICULTURALLY-RELATED SCIENCE AND TECHNOLOGY BASED USAID PROJECTS CONDUCTED BETWEEN \\ 1985 AND 1995}

Allen E. Bayles

Dissertation submitted to the Faculty of

West Virginia University

in partial fulfillment of the requirements for the degree of

Doctor of Education

In

Technology Education

David L. McCrory, Chair

Stacy Gartin

Joyce Meredith

Edward C. Pytlik

Richard Walls

December 15, 1998

Morgantown, West Virginia

Keywords: International Development, Third World Development, Evaluation

Copyright 1998, Allen E. Bayles 


\title{
IDENTIFYING THE TYPE AND APPROPRIATENESS OF THE EVALUATIONS OF SELECTED AGRICULTURALLY-RELATED SCIENCE AND TECHNOLOGY BASED USAID PROJECTS CONDUCTED BETWEEN 1985 AND 1995
}

\author{
Allen E. Bayles
}

(ABSTRACT)

A review of the literature indicated that baseline data that described how and what were being evaluated at the project level by agencies involved in third world development had not been published. This was a descriptive study using content analysis of the available evaluative reports for the USAID projects involved with the transfer of agriculturallyrelated technology identified in the National Science Foundation research project, Assessing the Literature on the Benefits of External Science and Technology Aid Assistance to Developing Countries (Pytlik, Vasudevan, Bayles \& Spitznogle, 1997).

The research concludes that impact evaluations were not being conducted at the project level. While over $60 \%$ of the projects were evaluated, socioeconomic impacts were included in less than $50 \%$ of these projects. The most frequent socioeconomic impacts reported were project sustainability and gender equity. Socioeconomic impacts that were infrequently reported were: who benefits, who does not benefit, target group participation, environmental effects, and the impact of the project on the nutritional status of a household. 


\section{DEDICATION}

This book is dedicated to the memory of my parents: Eugene Gilbert Bayles and Esther Evelyn (Ramsey) Bayles. Neither had the luxury of a high school education, yet they instilled in me the concept of education as a life long journey. So, thanks Mom and Dad, I'm still learning and my journey continues! 


\section{ACKNOWLEDGMENTS}

I would like to thank the members of my doctoral committee, Dr. Stacy Gartin, Dr. Joyce Meredith, Dr. Edward Pytlik, and Dr. Richard Walls, for their insight and encouragement in completing the requirements for this degree. A very special thanks to my committee chair, Dr. David McCrory, who helped me focus, clarify, and broaden my thinking.

There are many other people at West Virginia University I would like to thank for their help, suggestions, and encouragement. These include: Carol Spiroff, Char Allen, Dr. George Maughn, Dr. John Wells, Dr. Ann Nardi, Dr. Del Yoder, Dr. Mary Beth Bennett, and Dr. Robert Maxwell. I would also like to thank several of my cohorts in graduate school for their support. These include: Dr. Doug Eckert, Marcia Marcolini, Dr. Bryan Maser, Scott Chrisman, David Roth, Dr. Alicia Williams, Kim Kavanaugh, Dr. Lynn Dombrowski and Edwin Allen.

Within in the Morgantown community I would like to thank the Dr.'s Jerry Shive and Judi Elliott, Clay Pytlik, Rich Fleisher, Dr. Florita Montgomery, Dr. Patty Mulkeen, and Kaye McCrory. There are two other individuals at WVU who deserve special attention: Ms Robin Spitznogle and Dr. Faxian Yang. Robin kept my spirits high and my feet to the fire. Once Robin checked your numbers and agreed to them, you knew they were correct. Fax, my younger brother (at least in spirit), was always willing to give me encouragement and open the resource center whenever it would help me.

For giving me this opportunity I would like to thank Dr. Carol Webb and Dr. Dan Ezell of Clemson University. Additionally, for encouraging me to complete this dissertation, a special thanks goes to Dr. Dan Smith, Dr. Gary Wells and Dr. Chris Sieverdes.

Finally, a special thank you to my family for their support. Thank you David, Pamela, Paul, Mandy, Amy, John, and Danny. Thank you to my sister, Janice, and her family. Also, thanks to Dr. Bill Williams and Aunt Mary Helen, who even read my classroom attempts at scholarship and deemed it worthy. Most of all, thank you to my wife, Dr. Lucy Jackson Bayles. Your hours of patience, understanding and steadfast love gave me the encouragement to tackle and complete this task. 


\section{TABLE OF CONTENTS}

Chapter I: Introduction 1

Need for Study $\quad 3$

Problem Statement $\quad 4$

Purpose of Research $\quad 4$

Research Question $\quad 4$

Assumptions $\quad 5$

Limitations $\quad 5$

Procedure $\quad 5$

Definition of Terms $\quad 6$

Chapter II: Literature Review $\quad 8$

Green Revolution $\quad 8$

Need for Evaluations to Contain Socioeconomic Criteria 14

$\begin{array}{ll}\text { Evaluation Methodology } & 17\end{array}$

Chapter III: Procedure $\quad 26$

Database or Evaluation Frame 26

Evaluation Methodology 26

Validity and Reliability 31

Analysis $\quad 33$

Findings and Conclusions $\quad 33$

Chapter IV: Data Presentation and Analysis $\quad 34$

Study Question 1: What was evaluated? 35

Study Question 2: What types of evaluations were

completed and available to the public? 50

Study Question 3: In what ways were the evaluations

Chapter 5: Findings and Conclusions 76

Study Question 1: What was evaluated? 77

Study Question 2: What types of evaluations were

completed and available to the public? 79

Study Question 3: In what ways were the evaluations appropriate for determining socioeconomic impacts? 
Study Question 4: How might these evaluation results aid in the planning of future projects?

89

General Conclusions and Recommendations

90

Bibliography

91

Appendix A

108

Appendix B

110

Vitae

115 


\section{LIST OF TABLES}

Table 3.1: $\quad$ A Matrix of the Process Utilized to Develop the Content Analysis Instrument for this Research.

Table 4.1: $\quad$ Country (4*), Project Identification Number $\left(1^{*}\right)$, Project Dates $\left(2^{*}\right)$, Project Status $\left(7^{*}\right)$, Project Evaluated $\left(8^{*}\right)$ and Budget $\left(3^{*}\right)$ for African Projects

Table 4.2: $\quad$ Country (4*), Project Identification Number ( $\left.1^{*}\right)$, Project Dates $\left(2^{*}\right)$, Project Status $\left(7^{*}\right)$, Project Evaluated $\left(8^{*}\right)$ and Budget $\left(3^{*}\right)$ for Asian Projects

Table 4.3: $\quad$ Country (4*), Project Identification Number $\left(1^{*}\right)$, Project Dates $\left(2^{*}\right)$, Project Status $\left(7^{*}\right)$, Project Evaluated $\left(8^{*}\right)$ and Budget $\left(3^{*}\right)$ for Projects Conducted in Latin America and the Caribbean

Table 4.4: $\quad$ Types of Technology Being Transferred (6*)

Table 4.5: $\quad$ Comparison of Projects Evaluated by World Region ( $\left.5^{*}\right)$

Table 4.6: $\quad$ Project Identification $\left(1^{*}\right)$, Project Objectives $\left(15^{*}\right)$, Unexpected Outcomes (16*), Economic and Efficiency Indicators $\left(17.1^{*}\right)$, Planned Process $\left(17.2^{*}\right)$, Actual Process (17.3*), and Evaluation Purposes and Procedures (17.4*) Noted for African Projects

Table 4.7: $\quad$ Project Identification $(1 *)$, Project Objectives(15*), Unexpected Outcomes $\left(16^{*}\right)$, Economic and Efficiency Indicators (17.1*), Planned Process (17.2*), Actual Process $\left(17.3^{*}\right)$, and Evaluation Purposes and Procedures (17.4*) Noted for Asian Projects

Table 4.8: $\quad$ Project Identification $(1 *)$, Project Objectives $\left(15^{*}\right)$, Unexpected Outcomes (16*), Economic and Efficiency Indicators (17.1*), Planned Process (17.2*), Actual Process $\left(17.3^{*}\right)$, and Evaluation Purposes and Procedures $\left(17.4^{*}\right)$ Noted for Latin America and the Caribbean 
Table 4.9: $\quad$ Summary of Evaluation Types by World Regions

Table 4.10: Projects Conducted in Africa with Informal Type of Evaluations

Table 4.11: $\quad$ Projects Conducted in Asia with Informal Type of Evaluations

Table 4.12: $\quad$ Projects Conducted in Latin America and the Caribbean with Informal Type of Evaluations

Table 4.13: $\quad$ Projects Conducted in Africa with Formal Type of Evaluations

Table 4.14: Projects Conducted in Asia with Formal

Type of Evaluations

Table 4.15: Projects Conducted in Latin America and the Caribbean with Formal Type of Evaluations

Table 4.16: $\quad$ Projects Conducted in Africa with Interim Type of Evaluations

Table 4.17: $\quad$ Projects Conducted in Asia with Interim

Type of Evaluations

Table 4.18: Projects Conducted in Latin America and the Caribbean with Interim Type of Evaluations

Table 4.19: $\quad$ Projects Conducted in Africa with Final

Type of Evaluations

Table 4.20: $\quad$ Projects Conducted in Asia with Final Type of Evaluations

Table 4.21: $\quad$ Projects Conducted in Latin America and the Caribbean with Final Type of Evaluations

Table 4.22: $\quad$ Summary of types of evaluations completed by project number, country, type of technology involved, budget, and evaluation types 
Table 4.23: Average Budgeted Dollar Value per Project for Stakeholder Involvement in Evaluation Process by World Region 71

Table 4.24: Stakeholders Not Included in Evaluation Input

Table 4.25: Socioeconomic Impacts Evaluated for African Projects

Table 4.26: Socioeconomic Impacts Evaluated for Asian Projects

Table 4.27: $\quad$ Socioeconomic Impacts Evaluated for Latin America and the Caribbean Projects 


\section{CHAPTER I INTRODUCTION}

Development policies of the 1950s and early 1960s were based on the concept that if lesser developed countries (LDC) gain access to technology, they would soon grow beyond their third world status (Hayami \& Ruttan, 1971/1985). "This was the premise on which the diffusion model was adopted as a major foundation for technical assistance after World War II" (p. 255). Unfortunately, after the LDC's were presented with their gift-box of technologies, their agricultural productivity still did not increase. According to Hayami and Ruttan, agencies and organizations involved in trying to diffuse technologies had not given enough emphasis to the problem of site specific technologies. Technologies that worked in temperate climates, for example, often did not work in tropical climates.

The immediate fix to this problem was site specific agricultural research (Eicher \& Staatz, 1984). Funding, spearheaded by the Ford and Rockefeller Foundations, established the International Rice Research Institute (IRRI) in the Philippines and the International Center for Maize and Wheat Improvement (CIMMYT) in Mexico. These types of agricultural development became known as the green revolution. The green revolution focused agricultural research on the problems of a specific country. Unlike the diffusion model which failed to increase agriculture productivity in many developing countries, the production of wheat and rice increased dramatically (Ruttan, 1984). However, "the standard of living for all but a few persons remained unchanged or declined" (Pytlik, 1977, p. 24). The poor people of the country, particularly the rural poor, still suffered from an inadequate food supply, malnourishment, unemployment, and outright starvation.

Soon conflicting reports were being aired through the mass media. Some reports indicated that certain third world countries were now able to export rice, while others reported that the number of poor malnourished natives were increasing. This dichotomy 
of answers concerning the success or non-success of the green revolution development programs pointed out the problems of not evaluating programs more thoroughly. Pytlik (1977) recommended that development projects should be evaluated using an interdisciplinary procedure to better clarify their successes and/or failures. He compared two case studies, one successful and the other not successful. The comparison demonstrated the importance of considering all aspects of a development project. Too often development agencies had ignored the relationship between human, economic, political, and social development (Burkey, 1993). "The Third World is today littered with clinics, hospitals, training schools, water systems, community centres, and other social institutions which are dilapidated or in a terminal state of decline" (Burkey, 1993, p. 38).

Agencies connected to the United Nations began monitoring and evaluating agricultural projects in the mid 1970's (Malhotra, 1987). However, these efforts proved unsatisfactory.

Monitoring was found to be limited in scope; it covered physical and financial information on the vital linkage of the project with the intended beneficiaries. For the evaluation systems, the survey revealed that ambitions for measuring project impact in a limited span of years remain high and universal, but these ambitions are not matched by the achievements of the impact studies. Most of these have failed to provide even a sound data base, let alone allow for an analysis that would meet the high expectations of the designers. (Malhotra, 1987, p. $x$ )

Today the problem of adequately evaluating projects continues. In the World Bank's newsletter, Findings, Issue 73 (October, 1996) entitled, "Poverty in Sub-Saharan Africa: Issues and Recommendations," the authors concluded that poverty reduction in the region was not being addressed properly by the current World Bank projects. The study's recommendations included one to: "Hold management and staff accountable for ensuring the participation of all stakeholders in the formulation of assistance strategies 
and for achieving the Bank's stated objective of poverty reduction" (p. 3). Implied with this recommendation was the necessity for monitoring and evaluation.

Development projects have also failed to address the plight of poor women in LDCs. Burkey (1993) emphasized that development projects were planned by men and benefited men. This phenomena has resulted in each generation of women being in a worse condition physically, politically, economically, and socially. Part of the problem has stemmed from inappropriate evaluations which were used to determine the success or failure of the development process (Koblinsky, Timyan \& Gay, 1993). The assessments being reported did not reflect what was happening to women as the main food producers for their household. As resources were switched to produce a cash crop, women were often required to work in these fields before tending their family's food plots. Additionally, the best fields formerly used to provide the household with food were switched to producing the cash crop. With the best land now being used to produce nonfood crops and their workload increased, women suffered from the development policies of the 1980s promulgated by the World Bank and the International Monetary Fund (Koblinsky, et al.).

\section{Need for Study}

A review of the literature indicated that baseline data that described how and what were being evaluated at the project level by agencies involved in third world development had not been published. As discussed in more detail in Chapter II, the failure to adequately evaluate the impact of transferring agriculturally-related science and technology projects to LDCs during the period known as the green revolution created many hardships for certain populations in these countries while others prospered because of the increased agricultural productivity (Pearse, 1980; Wolf, 1986). Additionally, the conflicting news reports from these countries on the benefit or harm caused by these projects confused the people living in economically developed nations who supported these development efforts. 


\section{Problem Statement}

The problem of this research was to identify the type and appropriateness of the evaluations of selected agriculturally-related science and technology based United States Agency for International Development (USAID) projects conducted between 1985 and 1995.

\section{Purposes of Research}

The purposes of this research were to:

1. Provide information to field staff on types and appropriateness of evaluations being conducted by USAID.

2. Provide information to decision makers on the need for and reasons to support evaluating international development projects.

3. Provide other donor agencies with information on the types of evaluation and their appropriateness that were being used to evaluate third world development projects.

4. Provide data to program developers indicating the necessity for including valid and proper evaluation methods and techniques.

\section{Research Questions}

This research addressed the following questions regarding the selected USAID projects conducted between 1985 and 1995:

1. What was evaluated?

2. What types of evaluations were completed and available to the public?

3. In what ways were the evaluations appropriate for determining socioeconomic impacts?

4. How might these evaluation results aid in the planning of future projects? 


\section{Assumptions}

For the purposes of this research the following assumption was made; the data provided in the project records and evaluations were valid and accurate.

\section{Limitations}

This research was limited to:

1. Third world agricultural development projects involving the transfer of science and technology identified in the National Science Foundation research project, Assessing the Literature on the Benefits of External Science and Technology Aid Assistance to Developing Countries (Pytlik, Vasudevan, Bayles, \& Spitznogle, 1997). These projects were selected because they were the only projects for which data for the study could be found.

2. The available project reports retrievable from electronic data bases, agency project reports or appropriate libraries.

\section{Procedure}

This was a descriptive study using content analysis of the available evaluative reports for the USAID projects involved with the transfer of agriculturally-related technology identified in the National Science Foundation research project, Assessing the Literature on the Benefits of External Science and Technology Aid Assistance to Developing Countries (Pytlik, Vasudevan, Bayles, and Spitznogle, 1997). The literature review included three content areas: 1) Transferring agriculturally-related or rural economically-related science and technology development projects to the third world; 2) Socioeconomic or sociocultural impact of such transfers; and 3) Research and evaluation methodology related to this research.

Content analysis of the evaluations was based on the standards developed by the Joint Committee on Standards for Educational Evaluation (1994), Stufflebeam's (1983/1993) context, input, process, product (CIPP) model of evaluation, and Suchman's (1967/1973) development indicators. Additionally, indicators and methodology used was 
from Project Monitoring and Evaluation in Agriculture (Casley \& Kumar, 1987) and Monitoring and Evaluating Social Programs in Developing Countries (Valadez \& Bamberger, 1994) and other sources discussed in the literature review. From these sources a measuring instrument was developed to categorize and describe each of the projects in the population.

The content validity of the measuring instrument was determined by a panel of experts. Changes and additions recommended by the expert judges were incorporated in the measuring instrument. Reliability of the instrument was determined by using interrater statistical methodology. The results of the measuring instrument were analyzed by descriptive statistics. Percentages were calculated to describe the frequency of occurrences in the various categories. In addition, the types of project evaluations being conducted were compared to the project dollar value, the project location in the world, the type of agricultural activity the project represents, and the project evaluation date to look for trends. Finally, emerging themes which provided insight into the evaluations were noted and reported.

Findings, conclusions, and recommendations were made based on the analysis of the data gathered.

\section{Definition of Terms}

The terms used in this research were defined as follows:

Agriculture - The production, harvesting, processing, and/or storage of plants and animals for human use as food, feed, clothing, shelter and transportation (Derry \& Williams, (1993/1960).

Evaluation - Casley and Kumar (1987) define evaluation as the, "periodic assessment of the relevance, performance, efficiency, and impact of the project in the context of its stated objective" (p. 2).

Lesser Developed Countries (LDC) - See definition for Third World Countries. 
Monitoring - Casley and Kumar (1987) define monitoring as the, "continuous assessment both of the functioning of the project activities in the context of implementation schedules and of the use of project inputs by targeted populations in the context of design expectations" (p. 2).

Science - A body of knowledge founded on the methodology of the, "finding and stating of a problem, the collection of facts through observation and experiment, and the making and testing of ideas that need to be proven right or wrong" (Mish, 1994, p. 652).

Technology - "A system based on the application of knowledge, manifested in physical objects and organizational forms, for the attainment of specific goals" (Volti, 1995, p. 6).

Third World Countries - Those lesser developed countries of Africa, Latin America and the Caribbean, the Pacific, and Asia with per capita GNP less than $\$ 8,356$ and excluding the former Soviet block countries (World Bank, 1994).

United States Agency for International Development (USAID) - An agency of the United States government charged with the responsibility of aiding development in third world countries. 


\section{CHAPTER II}

\section{LITERATURE REVIEW}

Concern for the under-nourished and malnourished people of the third world countries has been a policy issue of the United States government since the conclusion of World War II (Eicher \& Staatz, 1984). This literature review focused on three areas of concern in identifying the type and appropriateness of the evaluations conducted by USAID agriculture-related science and technology projects. It began by looking at the historical basis for the problems connected with inadequate project evaluation. The research then reviewed the necessity for including socioeconomic or sociocultural indicators in the evaluation of development projects. Finally, the rationale for developing standards and the development process used in selecting the standards by which these evaluations were described was reviewed.

\section{Green Revolution}

The first apparently successful attempts at addressing world hunger and agricultural productivity became known as the "green revolution." Andrew Pearse (1980) summarized the thoughts of several authors including Theodore Schultz's book, Transforming Traditional Agriculture and Shigeru Ishikawa's book, Agricultural Development Strategies in Asia: Case Studies of the Philippines and Thailand concerned with the agricultural development policy referred to as the green revolution. Proponents of the strategy made the assumption that technology transfers were neutral in their impact on political and social structures. These development policies had, "neatly side-stepped the awkward and subversive ghosts of land reform, redistributive measures, institutional change, and structural transformations" (Pearse, 1980, p. 79). Proponents believed that green revolution or high yield agriculture policies needed five components to be successfully transferred: regionally specific research, knowledge transfer, physical inputs, market, and credit. Pearse defined these five points as: 
1. A technological 'package' or recipe produced in scientific research centres and designed to fit the environmental conditions of the region in which it is to be applied;

2. Arrangements whereby knowledge of this technology could be communicated to cultivators;

3. Measures to ensure the availability of physical inputs, i.e. High-Yielding Variety (HYV) seeds, fertilizers, pesticides, machinery and fuel;

4. Measures to favour the prospect of profitable sale sufficiently attractive to compensate for the greatly increased production costs and risks involved;

5. Indispensably, some system of credit so that payment for inputs and additional cultivation expenses could be financed, pending the receipt of income from the sale of the product after harvest. (Pearse, 1980, p. 79)

Initial evaluations of the green revolution's impact on third world countries were very positive. "At a time when famine seemed imminent, new varieties of wheat and rice introduced to Asia and Latin America along with fertilizers, pesticides, and mechanized farm equipment dramatically increased harvests" (Wolf, 1986, p. 5). Food production successes in India and Indonesia were touted in the world community to show other countries what could be accomplished. Lester Brown (1977) suggested that critics of the green revolution needed to consider the fate of the world's poor if the new technologies had not been introduced. Yet those dealing with agricultural development in LDCs were also noting problems and/or concerns.

Unfortunately, the overall evaluation of the green revolution had been based on using only gross national economic indicators, which resulted in gross overstatements of success (Wolf, 1986). One example, related by Wolf, of this type of analysis was the green revolution's effect on subsistence farmers.

The aggregate statistics hide a large group of Third World farmers who did not benefit from the new technologies: subsistence farmers raising food for their 
families on marginal, rainfed land. Because their agriculture remains unproductive and vulnerable to crop failure, drought, and natural catastrophe these rural people remain among the poorest in their societies. (p. 5)

When the analysis of the green revolution was changed from the macro-level to the microlevel, many of the problems became evident.

First, the new technologies changed the relationship between landowners and tenants. Pearse (1980) reported that prior to the introduction of new technologies the landowner's welfare was partially dependent on his tenants. Someone had to do the actual work, but higher yields changed this relationship. "As the profitability of the new technology for the well-funded entrepreneur is clearly demonstrated, ... the traditional tenancy arrangements [are] undermined, and the patron-client relationship becomes a tiresome encumbrance to the landowner" (p. 121). Wolf (1986) noted that, "relatively prosperous farmers who controlled more land, and so had the financial means to purchase fertilizers, pesticides, and equipment, gained most" (p. 17).

Foreign aid policies coupled with national policies also aggravated the traditional landowner-tenant relationship. For example, Owens and Shaw (1974) noted that Pakistan maintained the domestic wheat price at twice the world market price. The subsidization of both input and output prices resulted in economic decisions being made that hurt the LDC's farm workers.

At the same time the larger farmers have been paying only fifty cents on the dollar for the very same tractor for which a farmer in the United States pays a dollar on the dollar. With the price of tractors subsidized in this fashion, it pays the large farmer to replace his farm work force with tractors. But how are the displaced workers to earn a living? (Owens \& Shaw, 1974, pp. 56-57)

Lester Brown (1977) in an article entitled "Population and Affluence: Growing Pressures on World Food Resources" reached a similar conclusion. The rational decision resulting from the new varieties was to substitute machinery for labor. Evaluations which 
focused on the increased yields ignored the plight of workers who no longer had employment.

The new high-yielding varieties of wheat and rice require much more labor than the traditional varieties they replace. Realizing the full yield potential of the new seeds requires frequent fertilization and irrigation. This in turn requires careful and frequent weeding lest the fertilizer and water be converted into weeds rather than food. Higher yields require more labor at harvest time.

The risk is that farmers profiting from the use of the new seeds will want to invest their profits in Western-style mechanization. This tendency may be aggravated by low, subsidized interest rates on agricultural loans for farm mechanization. Rates that are too low, which is often the case, encourage farmers to substitute machinery for labor rather than to use the maximum amount of labor. (Brown, 1977, p. 36)

Additionally, as yields increased, the market price of the commodity decreased (Wolf, 1986). When farmers, who were unable to adopt the new technologies, managed to produce a surplus to take to market, they received less for it. Therefore, the green revolution left these poor farmers poorer.

Second, peasant farmers experienced the advent of the new technologies as a change from internal to external dependencies (Pearse, 1980). No longer do the farmers produce their own seed and fertilize it with the dung from their beast of burden. Instead, they must look to outside sources to provide their seed, fertilizer and machinery. Pearse summarized these difficulties.

It biases the distribution of advantage in favour of those who have the experience and social attributes necessary for confronting the city and bureaucracy, the printed instructions, and the political caucuses; and it puts a relative handicap on those whose assets include traditional knowledge of the local idiosyncrasies of 
soil and climate, and whose energies are absorbed by the labours of husbandry rather than in manipulating the rural-urban nexus.

External dependence implies a swing away from local self-reliance; it implies the local community and the individual productive unit becoming a part of a larger system of production and exchange that has a potential for diversifying and enriching life and livelihood. In the agrarian society with a low technological level, most rural families must produce the food they live by, and in this sense they enjoy some security, though subject to the chances of regional catastrophe and local extortion. The linkage established by the new technology between the local community of producers and the larger society tends to withdraw much of the decision-making autonomy from the former, and subjects it to national and international episodes of politics and the repercussions of distant war. (Pearse, 1980, pp. 159-160)

Owens and Shaw (1974) shared an example reported by Francine Frankel which illustrated the external dependency created when shifting to a market oriented economy that many small farmers could not overcome.

Unequal access to market is one of the reasons why the Green Revolution in India benefited mostly the large farmers. "The cooperative marketing societies do not have purchasing agents in the village at all. Cultivators wishing to use their services must arrange their own transport to the market town. Worse still, the majority of marketing societies lack funds to make outright purchases of foodgrains from cultivators or even to offer substantial advances against anticipated sales proceeds. They generally act only as commission agents." (p.72) Third, unlike farmers in industrialized nations, peasant farmers could not separate the household economy from that of the farm's (Pearse, 1980). Before the new technologies were introduced, the subsistence farmers were already in debt to wealthier landowners. They borrowed the resources necessary to feed their families when the food 
secured from their land did not last until the next harvest. Adopting the new technologies would have doubled or tripled their debt load. Therefore, the poorer farmers were unwilling to increase their debt load to try the new technologies. Additionally, Pearse noted that the indebtedness was often tied to the individual's labor. Thus, when the new technology appeared, their labor was already controlled by the larger landowners.

Fourth, economic status was not the only difference between the few successful adopters and the not so successful. Pearse (1980) found that traditional indigenous social structures and customs continued to play a role. Many communities were still divided by caste systems or religious differences. The superior groups were able to take advantage of the new innovations, while the less fortunate were unaware of the possibilities. Pearse reported on one case study where "the lower strata were found to have been excluded from places where public broadcasts were relayed and, being also illiterate, were still ignorant of most of the essential data content of welfare and development programmes" (p. 170).

Fifth, the promoters of the green revolution strategy failed to recognize the impact that gender bias had on agricultural development. Jacobson (1992) reported that the green revolution affected women negatively in two ways: their access to land and the wage rate their labor could command. Jacobson noted that:

With government and private interests controlling much of the once commonlyowned land used by subsistence producers to collect fuel and fodder, women were forced to go farther afield to meet their families' needs. At the same time, the replacement of human labor by tractors increased competition for, and lowered the wages of, the much smaller number of jobs available. (Jacobson, 1992, p. 8) In summary, a more thorough analysis concluded that the green revolution had many short comings that needed to be addressed if the United States wanted to help the poor people living in LDCs. Owens and Shaw (1974) concluded that, "the Green Revolution has widened the distance between large and small farmers, between landlords 
and tenants, between the government and the governed" (p. 72). Pearse (1980) summarized his critique of the green revolution:

Research output can have an important influence if it is available in the right form, at the right time, and in the right place....

Unfortunately, the net effect of much research is to throw an enigmatic veil over the true character of social and economic problems by hiding them in academic virtuosity and obscurantism. Social research must play a more positive role by revealing social realities in the light of universally humane values. (p. 248)

\section{Need for Evaluations to Contain Socioeconomic Criteria}

Twenty years ago Pytlik (1977) concluded that an interdisciplinary approach was necessary to successfully develop and implement third world development projects. His research involving case studies of two third world development projects (one considered successful and the other not successful) concluded that:

A sufficient number of relevant interdisciplinary dimensions were taken into account during the planning and implementation of the Comilla Rural Development Project.

The failure to take into account the relevant interdisciplinary dimensions of a development project, during its planning and implementation stages, decreased the chances for successfully integrating innovative practices into the target society.

An interdisciplinary methodology can provide a proper accounting of the many dimensions of a development project. (p. 173)

Conrad Kottak (1991) reached a similar conclusion concerning the value of using sociological expertise in the development and implementation of development projects. Kottak's study was based on two different types of evaluation studies carried out by the World Bank. Both the Project Performance Audit Reports (PPAR) and Impact Evaluation Reports (IER) were prepared by the Operations Evaluation Department. This independent department of the World Bank reports directly to the Bank's Executive Directors. The 
sample included fifty-seven PPARs and eleven IERs. In selecting the sample projects Kottak (1991) noted that:

[The projects] were chosen purposely to facilitate the identification and understanding of social and cultural issues in project design, implementation, and impact. Individual PPARs were selected for secondary analysis on the basis of the quality, detail, and depth of the material related to social issues, and not in order to build a random sample and determine frequencies. (p. 434)

Kottak's (1991) analysis concluded that "the thirty projects in which project design was judged to be compatible with traditional cultural and local socioeconomic conditions in the targeted area had an estimated rate of return at audit of 18.3 percent, compared with 8.6 percent for the twenty-seven projects in which sociocultural incompatibilities were identified" (p. 437).

Sociocultural considerations need to be included within a project's design and evaluation because they form the baseline for how recipients may react to a new set of circumstances (Cook, 1991). The researcher further clarified this by saying:

If farmers are to invest additional time in agriculture in response to a price incentive, they may have to decrease the time they spend on certain social or ritual activities which also have value for them. Expecting women to benefit from the marketing of cash crops implies a series of assumptions regarding the ability of women to travel, to interact with strangers, to handle money, and to participate in household decision making. Increased utilization of education, health, extension, or credit services may depend not only on improved access but also on cultural norms governing the patterns of interaction among the people in the project area, and between them and various types of outsiders.

... Community contributions must be carefully planned so as not to penalize the poorer sectors of society while the wealthier individuals reap the full benefits of 
the improvement. (This danger is particularly prevalent where there is a large landless labor force in rural areas.) (Cook, 1991, pp. 413-414)

Eckman (1994) reported on three different development projects where "conventional project monitoring and evaluation techniques can prevent the detection of underlying problems that determine project success or failure" (p. 6). While traditional evaluative procedures focus on the number of new varieties used and the hectares planted, these procedures do not note socioeconomic impacts such as gender bias, equity, or sustainability.

Tilberg \& Haan (1995) also suggested a broader range of subjects be included in project evaluations. The evaluative function should address the impact on intended beneficiaries and project sustainability. However, the authors concluded that "the limited availability of project data proved to be a major hindrance to effective monitoring and evaluation" (p. 37). Gow and Morss (1988) reached a similar conclusion. "Information generated by development projects is often used ineffectively or not used at all: Information systems are designed but never implemented; data are collected but never processed; or the results are made available but are used only by researchers" (p. 1410).

Valadez and Bamberger (1994) indicated that several studies have shown gender bias often leaves women in worse shape after a development project had been completed. The problem revolved around the woman's responsibility to provide basic necessities for her family. "Agricultural modernization, which normally involves an increasing commercialization of crops, shifts control of the revenue to the husband. Thus, even though total household income may increase, women will control a smaller proportion of the total income, and household expenditures on food and other basic necessities may actually decrease" (p. 69).

Michael Cernea (1991) lamented that "many sociologist [sic] have been generating evaluation findings that should have led to the modification of subsequent programs. ... 
Instead they watched new projects without sociological inputs being designed again by econocrats oblivious to earlier findings and repeating the same mistakes" (p. 12).

Robert Chambers (1991) suggested four reasons for not including relevant sociocultural information in designing projects: (a) the projects primary architects were engineers, economists, and statisticians who lacked the background and/or interest in sociocultural paradigms; (b) poor people lacked visibility and political power; (c) attempts to provide sociocultural information lacked timeliness, cost effectiveness, and relevancy; and (d) the sociocultural information gathered did not reflect input and interpretation from those studied but became part of the outsiders data bank.

\section{Evaluation methodology}

When reviewing third world development project evaluations it is also beneficial to keep in mind the cautions presented by Valadez and Bamberger (1994) that the reported results may be flawed or misleading. The authors shared an analysis of the problem by Robert Chambers who identified six biases which might limit the evaluation of agricultural and rural development projects. The six limitations or biases were: spatial, project, person, dry-season, diplomatic, and professional.

- Spatial bias. Project staff and researchers do not stray too far from urban centers, tarmac roads and roadside projects.

- Project bias. Agencies plan in terms of, and evaluate, projects and show little interest in what happens to the rural poor who are usually not affected (at least directly) by projects.

- Person bias. "Rural development tourists," as Chambers calls them, tend to get most of their information from elite groups, males, and users and adopters of new technology; and from people who are active, well, and present.

- Dry-season bias. Experts make few visits during the rainy season so they rarely get to appreciate the impacts of flooding. 
- Diplomatic bias. A combination of politeness, fear, embarrassment, and language problems frequently deter visitors from speaking to the poor, the underprivileged, or those who are not directly involved in the projects. Often it is considered discourteous to insist on meeting with people not on the itinerary prepared by your hosts.

- Professional bias. Professional visitors are frequently drawn to the wealthier, better-educated, and more progressive farmers, since they are the ones best able to discuss the topics of interest to the outside agronomist, extension worker, or economist. (p. 117)

The transfer of science and technology projects to third world countries hinges on an educational process. Beginning in 1975 The Joint Committee on Standards for Educational Evaluation (1994) proposed a set of standards that should be considered when evaluating educational efforts. The originating committee had representation from 12 organizations, while The Program Evaluation Standards, 2nd Edition had representation from 15 organizations. These organizations included the American Psychological Association, the American Educational Research Association, the American Evaluation Association, the National Council on Measurement in Education, and the Canadian Society for the Study of Education. The 30 standards were divided into four categories: utility standards, feasibility standards, proprietary standards, and accuracy standards.

Utility standards defined the evaluation by identifying everyone involved in the evaluation process (The Joint Committee on Standards, 1994) Descriptors in this area included stakeholder and evaluator identification, what was evaluated and other items that measured the fit between the information to be generated and the intended audience.

The feasibility standards (The Joint Committee on Standards, 1994) attempted to ensure that the evaluation design was workable with the limitations within which the project or program operated. Considerations within this set of standards included recognition of cost and political constraints. 
Descriptors which considered the rights of the project recipients, human interactions, and conflicts of interest were grouped as proprietary standards. Finally the standards labeled accuracy standards related to the items most people think of when evaluations are mentioned. These included the program documentation, the data gathered to evaluate the project including the analysis of the data, and the conclusions the evaluation supported (The Joint Committee on Standards, 1994). Together, all 30 standards evaluated the evaluation process.

Robert Stake (1983) credits Michael Scriven with this definition of evaluation. "Evaluation is an observed value compared to some standard" (p. 291). In attempting to answer the questions related to this research, it is necessary to develop the criteria by which agriculturally-related science and technology projects should be evaluated or described.

Suchman (1967/1973) in his Evaluative Research: Principles and Practice in Public

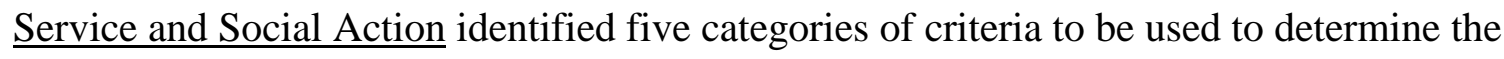
success of a public service program. The five categories were: effort, performance, adequacy of performance, efficiency, and process. Effort described what was done and the quality of those activities. Performance assessed the outcomes to the targeted audiences against the objectives of the project. When the outcomes were measured against the proposed amount of change to accrue to the beneficiaries, the adequacy of performance could be evaluated.

Efficiency (Suchman, 1967/1973) was used to evaluate the program in terms of monetary cost, personnel time and numbers, and public convenience. Finally, process evaluation was used to determine "a "causal" connection between what was done and the results that were obtained" (p. 66).

Stufflebeam (1983/1993) developed an evaluation model commonly referred to as CIPP. The acronym CIPP identified the four types of evaluation which were: context evaluation, input evaluation, process evaluation, and product evaluation. When 
considering replicating projects, avoiding potential problems, or enhancing positive benefits of development projects, information provided by these four types of evaluation would be extremely valuable.

Context refers to the identification of the needs, challenges, problems, and strengths faced by the targeted audience. "The results of a context evaluation should provide a sound basis for adjusting its existing goals and priorities and targeting needed changes" (Stufflebeam, 1983/1993, p. 128). When attempting to judge the outcomes of a project, one assessment was whether or not the project addressed the needs identified by the context evaluation.

Input evaluation judged alternatives that might be used to address a problem or concern (Stufflebeam, 1983/1993). It answered the questions as to why the choices that were made to implement the project were made. Once the perspective had shifted from what activities and methods were used to implement the project, to one of how was the implementation proceeding, the concern became one of process evaluation. This evaluation not only provided accountability but knowledge on how to carry out the program.

"The purpose of a product evaluation is to measure, interpret, and judge the attainments of the program" (Stufflebeam, 1983/1993, p.134). Not only are the outcomes judged but the project results should be reviewed for unexpected outcomes that might be considered positive as well as negative.

Stufflebeam (1983/1993) pointed out that these four types of evaluations were synergistic in addition to providing specific answers to the holistic evaluation of a project or program.

Casley and Kumar (1987) prescribed specific items to be evaluated when reviewing agriculture-related development projects. To accomplish this evaluation the authors divided the focus into three areas: "performance; output, effects, and impact; and economic and financial efficiency" (p. 101). 
Performance evaluation (Casley \& Kumar, 1987) was concerned with project identification, preparation, appraisal, project specification, timeliness of start-up and implementation, services and inputs provided, beneficiary coverage and response, managerial performance, and financial performance. This classification parallels Stufflebeam's (1983/1993) first three segments of his CIPP model: context, input, and process and Suchman's (1967/1973) categories of effort and process. Stufflebeam's product evaluation closely coincides with Casley's and Kumar's other two classifications of evaluations: 1) output, effects and impact, and 2) economic and financial efficiency and Suchman's categories of performance, adequacy of performance, and efficiency.

Casley and Kumar (1987) correctly pointed out that the performance evaluation might suggest that a project was very successful. For example, the project may have called for the construction of rural health centers. A performance evaluation might indicate that all of these centers were successfully constructed, but if the people for which the centers were constructed were not using them, the project would still be a failure. An evaluation of the outputs, effects, and impact of the project would catch this type of discrepancy when trying to evaluate the success of development projects. Therefore, these types of evaluations try to determine what changes occurred because of the project.

The authors' third type of evaluation, economic and financial efficiency, was the kind of information for which most projects have been historically evaluated. Casley and Kumar (1987) indicated that recalculating economic rates of return enable the donor to determine how accurate the estimated rates of return were. Since funding agencies have limited budgets, the estimated rate of return became an important factor in determining which projects were to receive funding.

In addition to the three types of focus for evaluations, Casley and Kumar (1987) discuss three types of evaluations in relation to the project cycle: 1) interim or midterm evaluations which are conducted during the project cycle; 2) terminal or completion 
evaluations which are conducted at the conclusion of the project; and 3) ex post or impact evaluations which are conducted several years after a project ends.

Midterm evaluations check on management and staff proficiency, acquisition of project supplies, workable delivery systems, progress of any infrastructure construction, volume and quality of inputs and services, the target audience response, indications of project outputs, and the project's environmental impact. The interim or midterm evaluation can be used to modify the project activities, objectives, or environmental impact, plus correct staffing, supply, or construction problems (Casley and Kumar, 1987).

Lessons from evaluations at the end of a project can be used to adjust strategies for future projects, plus allow funding agencies to make adjustments in other currently ongoing projects when the situations were similar enough. Casley \& Kumar (1987) point out that the terminal evaluation might "include studies of the beneficiaries' perceptions of the project's benefits and of the impact on their lives" (p. 109).

Sometimes projects which appear successful or unsuccessful when evaluated at the project's completion, actually turn out the opposite when evaluated at a later date. Impact evaluations provide information on the long term impact of a development project. Casley and Kumar (1987) share one World Bank project which illustrated this point.

The main achievements of an irrigation and land settlement project in Latin America were visible only years after its completion. An ex post evaluation report prepared six years after completion observed that, in spite of difficulties experienced during implementation, the project did indeed achieve its basic goal of stable settlement in the years following completion.

The most striking outcome in the years between its completion and the review was that farmers established strong and efficient organizations. This may have been mostly the result of their surprising response to problems they had encountered during the execution of the project. Less than ideal conditions may have worked in the project's favor: The close cooperation of farmers necessitated 
by the remoteness of the project area and the strong pioneer spirit of the settlers and government officials helped overcome many of the difficulties associated with new settlements.

Another unanticipated response was a shift in the type of crops grown in the project area. Decreases in the amount of cultivated land and drops in cropping intensity occurred in some areas of the project because of technical design problems. Farmers responded to this potentially serious situation by shifting to higher value crops, including fruit and rice. This change in turn led settlers and private enterprises to establish fruit-processing facilities and other agroindustries which became highly successful.

Despite errors in the original project design and other setbacks, lasting progress was made. According to the ex post evaluation report, in the years after completion the farmers progressively and successfully took over project responsibilities and even began to function administratively as substitutes for government institutions. (Casley and Kumar, 1987, pp. 109-110) In addition to measuring expected production increases (Casley \& Kumar, 1987) as a result of the project, five socioeconomic indicators were suggested: income and living standards, nutrition, target group participation, status and role of women, and the environment.

Because many individuals were reluctant to disclose their actual income, other methods were required to estimate this measurement (Casley \& Kumar, 1987). One of the indicators that could be used to determine income and living standards was marketing receipts of a cash crop. By visiting with the buyers of agricultural commodities, the amount of money a small farmer earned could possibly be determined. Another possible indicator was expenditures. Many more people seemed willing to disclose the cost of things. This information does not exactly equal income, but where caution is used in the gathering of this information, it may be the best method. A third possible indicator was 
housing quality. This method allowed for direct observations by the evaluator. Another directly observable indicator mentioned by the authors was possessions. Additionally, the availability of community facilities was also listed as a standard of living indicator.

Nutritional status was specified (Casley \& Kumar, 1987; Koblinsky, Timyan, \& Gay, 1993) because it was usually an easier indicator on which to gather data. Because children are the most sensitive to malnutrition, the indicators already developed use children as the measurement target. Indicators included weight at birth, weight for age, height for age, and weight for height. Additionally, the authors pointed out that infant and child mortality rates and morbidity rates were also used.

Target group participation was designed to measure the involvement of the target group in the project (Casley \& Kumar, 1987). Their involvement was usually through some kind of organization. Therefore, the indicators revolved around determining the number of new or reorganized organizations, their membership, the proportion of the target population that are members or recipients of its services, proportion attending meetings, etc.

Gender equity was a concern with agriculture-related science and technology projects because the different roles into which women were forced (Beneria \& Feldman, 1992; Casley \& Kumar, 1987; Karl, 1995). Their roles could be divided into types of participation: 1) responsibility for specific crops; 2) responsibility for her own separate plots; 3) responsibility for specified tasks within the production system, and; 4) operating the entire farm system because the male members of the family were absent. Murphy (1995) suggested five questions evaluators should ask when analyzing gender equity at the project level. The two questions most critical to this research were whether or not men and women benefited equally and did some groups of people access new resources that allowed them to enter a formerly atypical role.

Environmental considerations were often overlooked (Burkey, 1993; Casley \& Kumar, 1987; Schuurman, 1993). Considerations that need to be monitored included: soil 
productivity, land use management, fertilizer and pesticide application, the assurance of human livelihood, and the incidence of environmentally related diseases.

Valadez and Bamberger (1994) discussed several questions that project evaluations should be designed to answer. These included: "What impacts is [sic] the project having on different groups? Who benefits and who does not? Are any groups worse off as a result of the project" (p. 21)? "How are project benefits distributed between different geographical and income groups" (p. 23)? And, "Is the project producing the intended benefits" (p. 24)?

In addition to the questions to be asked, Valadez and Bamberger (1994) listed six main methods of collecting data. These were using secondary data, sample surveys, panel studies, direct observation, participant observation, and group meetings. A nongovernment organization (NGO) evaluation guide (Ramashia \& Rankin, 1995) listed similar methods. These included reviewing existing documents, interviews including unstructured and structured as well as individual or group, observation, and questionnaires. 


\section{CHAPTER III \\ PROCEDURE}

The problem of this study was to identify the type and appropriateness of the evaluations of selected agriculturally-related science and technology based USAID projects conducted between 1985 and 1995 identified in the National Science Foundation project database (Pytlik, et al., 1997). This is a descriptive research study which used content analysis to address four study questions regarding the selected USAID projects: 1) What was evaluated? 2) What types of evaluations were completed and available to the public? 3) In what ways were the evaluations appropriate for determining socioeconomic impacts? 4) How might these evaluation results aid in the planning of future projects?

Relevant literature (see Chapter II) was reviewed in the area of third world development and the evaluations of that effort. Literature concerned with the socioeconomic impact of projects and programs on LDCs were also reviewed. Finally, the background for a research methodology to address the concerns of this research paper were discussed.

\section{Database or Evaluation Frame}

The projects evaluated in this study were compiled for a National Science Foundation research project entitled, Assessing the Literature on the Benefits of External Science and Technology Aid Assistance to Developing Countries (Pytlik, et al., 1997). Projects were categorized into six types: health, agriculture, infrastructure, economic development, education, and environment. There were 147 agriculturally-related science and technology projects identified by USAID project numbers and geographic location specific to a country.

\section{Evaluation Methodology}

In 1994 The Joint Committee on Standards for Educational Evaluation published The Program Evaluation Standards, $2^{\text {nd }}$ Edition. The Joint Committee had representation from 15 social science organizations, including the American Psychological Association and the American Educational Research Association. The transfer of science and technology projects to third world countries depends on an educational process; four of 
these standards were selected as a basis for this study. The four standards were selected because they address the research questions of this study and are discussed more fully later in this chapter. Additionally, the evaluative criteria discussed in Chapter Two that added focus to the four broad standards of The Joint Committee were used to develop the questions for the data collection instrument used in this research. These included the CIPP model developed by Stufflebeam (1983/1993), the agricultural development project evaluation indicators developed by Casley and Kumar (1987), the development indicators developed by Suchman (1967/1973), and the questions suggested by Valadez and Bamberger (1994). The research questions and the criteria for a data collections instrument was then submitted to a panel of experts with expertise in third world development for validation. Recommendations the panel made were used to develop the final version of a data collection instrument which is included in Appendix A.

Table 3.1 shows the relationship between the research questions, the standards selected from The Joint Committee on Standards (1994), and the other sources utilized to provide focus to develop the data collection instrument that was then reviewed and modified by a panel of experts knowledgeable of third world development.

Table 3.1:

A Matrix of the Process Utilized to Develop the Content Analysis Instrument for this Research.

\begin{tabular}{|l|l|l|}
\hline \multicolumn{1}{|c|}{$\begin{array}{c}\text { Selected Standard } \\
\text { (The Joint Committee on }\end{array}$} & \multicolumn{1}{|c|}{$\begin{array}{c}\text { Questions Developed with } \\
\text { Additional References } \\
\text { (Where Appropriate) }\end{array}$} & $\begin{array}{c}\text { Content } \\
\text { Analysis Item } \\
\text { Number } \\
\text { (Appendix A) }\end{array}$ \\
\hline $\begin{array}{l}\text { The first standard selected } \\
\text { was related to stakeholder } \\
\text { identification. "Persons } \\
\text { involved in or affected by } \\
\text { the evaluation should be } \\
\text { identified, so that their } \\
\text { needs can be addressed" (p. } \\
\text { 25). The committee pointed }\end{array}$ & $\begin{array}{l}\text { Were all affected stakeholders } \\
\text { identified? }\end{array}$ & 14.1 and 14.3 \\
If no, which groups were left out? & 14.2 and 14.4 \\
\hline
\end{tabular}




\begin{tabular}{|c|c|c|}
\hline $\begin{array}{c}\text { Selected Standard } \\
\text { (The Joint Committee on } \\
\text { Standards, 1994) }\end{array}$ & $\begin{array}{c}\text { Questions Developed with } \\
\text { Additional References } \\
\text { (Where Appropriate) }\end{array}$ & $\begin{array}{c}\text { Content } \\
\text { Analysis Item } \\
\text { Number } \\
\text { (Appendix A) }\end{array}$ \\
\hline $\begin{array}{l}\text { efforts may be necessary to } \\
\text { promote the appropriate } \\
\text { inclusion of less powerful } \\
\text { groups or individuals as } \\
\text { stakeholders, such as racial, } \\
\text { cultural, or language } \\
\text { minority groups" (p. } 25) \text {. }\end{array}$ & & \\
\hline $\begin{array}{l}\text { The second standard was } \\
\text { identified as information } \\
\text { scope and selection. } \\
\text { "Information collected } \\
\text { should be broadly selected } \\
\text { to address pertinent } \\
\text { questions about the program } \\
\text { and be responsive to the } \\
\text { needs and interests of } \\
\text { clients and other specified } \\
\text { stakeholders " (p.37). An } \\
\text { evaluation should } \\
\text { selectively weigh available } \\
\text { information based on its } \\
\text { importance to the } \\
\text { stakeholders when deciding } \\
\text { what information to include } \\
\text { in the report. Additionally, } \\
\text { the evaluation should } \\
\text { "assess the program in }\end{array}$ & $\begin{array}{l}\text { Research Question 1: What was } \\
\text { evaluated? } \\
\text { Were unexpected positive or negative } \\
\text { outcomes assessed (Stufflebeam, } \\
\text { 1983/1993)? } \\
\text { Were socioeconomic impacts included } \\
\text { in the project goals (Stufflebeam, } \\
\text { 1983/1993; Casley \& Kumar, 1987)? } \\
\text { Research Question 3: In what ways } \\
\text { were the evaluations for determining } \\
\text { socioeconomic impacts? } \\
\text { Were socioeconomic impacts } \\
\text { evaluated (Casley \& Kumar, 1987; } \\
\text { Cook, 1991)? } \\
\text { Were changes in income and/or living } \\
\text { standards evaluated (Casley \& Kumar, } \\
\text { 1987)? } \\
\text { Were changes in the nutritional status } \\
\text { of households in the project area }\end{array}$ & 18 \\
\hline
\end{tabular}




\begin{tabular}{|c|c|c|}
\hline $\begin{array}{c}\text { Selected Standard } \\
\text { (The Joint Committee on } \\
\text { Standards, 1994) }\end{array}$ & $\begin{array}{c}\text { Questions Developed with } \\
\text { Additional References } \\
\text { (Where Appropriate) }\end{array}$ & $\begin{array}{c}\text { Content } \\
\text { Analysis Item } \\
\text { Number } \\
\text { (Appendix A) } \\
\end{array}$ \\
\hline $\begin{array}{l}\text { terms of all important } \\
\text { variables (e.g., } \\
\text { effectiveness, harmful side } \\
\text { effects, costs, (and) } \\
\text { responses to learner needs" } \\
\text { (p. } 37) .\end{array}$ & $\begin{array}{l}\text { evaluated (Casley \& Kumar, 1987)? } \\
\text { Was target group participation } \\
\text { evaluated (Casley \& Kumar, 1987)? } \\
\text { Were which individuals benefited and } \\
\text { which individuals did not benefit from } \\
\text { the project evaluated (Valadez \& } \\
\text { Bamberger, 1994)? } \\
\text { Was the project's effect on the } \\
\text { environment evaluated (Casley \& } \\
\text { Kumar, 1987)? } \\
\text { Was the project's continuation or } \\
\text { sustainability evaluated (Casley \& } \\
\text { Kumar, 1987)? } \\
\text { Were other socioeconomic indicators } \\
\text { evaluated? If yes, list. }\end{array}$ & $\begin{array}{l}19.3 \\
19.4,19.5\end{array}$ \\
\hline $\begin{array}{l}\text { The third standard was } \\
\text { related to program } \\
\text { documentation. "The } \\
\text { program being evaluated } \\
\text { should be described and } \\
\text { documented clearly and } \\
\text { accurately, so that the } \\
\text { program is clearly identified } \\
\text { " (p. 127). This description } \\
\text { should include not only how } \\
\text { the program was actually } \\
\text { implemented, but also how }\end{array}$ & $\begin{array}{l}\text { Research Question 1: What was } \\
\text { evaluated? } \\
\text { Were all project objectives evaluated } \\
\text { (Suchman, 1967/1973; Stufflebeam, } \\
\text { 1983/1993)? } \\
\text { Were socioeconomic impacts included } \\
\text { in the project's goals (Stufflebeam, } \\
\text { 1983/1993; Casley \& Kumar, 1987)? } \\
\text { If yes, list. } \\
\text { Was the planned project process } \\
\text { evaluated (Suchman, 1967/1973)? } \\
\text { Was the actual project process }\end{array}$ & $\begin{array}{l}17.2 \\
17.3\end{array}$ \\
\hline
\end{tabular}




\begin{tabular}{|c|c|c|}
\hline $\begin{array}{c}\text { Selected Standard } \\
\text { (The Joint Committee on } \\
\text { Standards, 1994) }\end{array}$ & $\begin{array}{c}\text { Questions Developed with } \\
\text { Additional References } \\
\text { (Where Appropriate) }\end{array}$ & $\begin{array}{c}\text { Content } \\
\text { Analysis Item } \\
\text { Number } \\
\text { (Appendix A) } \\
\end{array}$ \\
\hline $\begin{array}{l}\text { it was proposed to be } \\
\text { implemented. }\end{array}$ & $\begin{array}{l}\text { evaluated? } \\
\text { What was the dollar value of the } \\
\text { project? } \\
\text { In what world region and country was } \\
\text { the project located? } \\
\text { What type of agricultural project (e.g., } \\
\text { agronomic, pastoral, animal, or forest) } \\
\text { was it? }\end{array}$ & 4,5 \\
\hline $\begin{array}{l}\text { Fourth, closely related to } \\
\text { the program documentation } \\
\text { standard was the standard } \\
\text { for describing purposes and } \\
\text { procedures. "The purposes } \\
\text { and procedures of the } \\
\text { evaluation should be } \\
\text { monitored and described in } \\
\text { enough detail, so that they } \\
\text { can be identified and } \\
\text { assessed"(p. 137). The } \\
\text { purposes of the evaluation } \\
\text { should be listed in the } \\
\text { evaluation objectives. "The } \\
\text { evaluation procedures } \\
\text { include the ways in which } \\
\text { the data and information are } \\
\text { gathered, organized, }\end{array}$ & $\begin{array}{l}\text { Research Question 1: What was } \\
\text { evaluated? } \\
\text { Did the evaluators indicate the purpose } \\
\text { and procedures for the evaluation? } \\
\text { Research Question 2: What types of } \\
\text { evaluations were completed and } \\
\text { available to the public? } \\
\text { Was the project evaluated? } \\
\text { Was there an informal interim or mid- } \\
\text { term evaluation conducted (Casley \& } \\
\text { Kumar, 1987)? } \\
\text { Was there a formal interim or mid- } \\
\text { term evaluation conducted (Casley \& } \\
\text { Kumar, 1987)? } \\
\text { Was there an informal terminal or } \\
\text { completion evaluation conducted } \\
\text { (Casley \& Kumar, 1987)? } \\
\text { Was there a formal terminal or }\end{array}$ & $\begin{array}{l}8 \\
13.1\end{array}$ \\
\hline
\end{tabular}




\begin{tabular}{|c|c|c|}
\hline $\begin{array}{c}\text { Selected Standard } \\
\text { (The Joint Committee on } \\
\text { Standards, 1994) }\end{array}$ & $\begin{array}{c}\text { Questions Developed with } \\
\text { Additional References } \\
\text { (Where Appropriate) }\end{array}$ & $\begin{array}{c}\text { Content } \\
\text { Analysis Item } \\
\text { Number } \\
\text { (Appendix A) }\end{array}$ \\
\hline $\begin{array}{l}\text { analyzed, and reported to } \\
\text { meet or satisfy the } \\
\text { evaluation purpose" (p. } \\
137) \text {. }\end{array}$ & $\begin{array}{l}\text { completion evaluation conducted } \\
\text { (Casley \& Kumar, 1987)? 13.5]? } \\
\text { Was there an informal impact or ex } \\
\text { post evaluation conducted (Casley \& } \\
\text { Kumar, 1987)? } \\
\text { Was there a formal impact or ex post } \\
\text { evaluation conducted (Casley \& } \\
\text { Kumar, 1987)? }\end{array}$ & 13.6 \\
\hline
\end{tabular}

\section{Study Question 4: How Might These Evaluation Results Aid in the Planning of}

\section{Future Projects?}

The information already collected for the previous three questions was used to determine the answer to this question plus relevant insights from the literature. A major concern was whether or not evaluations were conducted (Tilberg \& Haan, 1995) and if conducted, then made available to other people involved in planning development projects for LDCs. Other authors caution though that for these results to be of value the planners must utilize them (Gow \& Morss, 1988; Cernea, 1991).

In addition to the descriptive statistics tabulated for each project evaluation, emergent themes were identified based on the qualitative methodology described by Patton (1990/1980) and Guba and Lincoln (1982). "The qualitative analyst's effort at uncovering patterns, themes, and categories is a creative process that requires making carefully considered judgments about what is really significant and meaningful in the data" (Patton, 1990/1980, p.406). Guba and Lincoln (1982) referred to this as "an emergent (rolling, cascading, unfolding) design" (p. 325).

\section{Validity and Reliability}

Validity is concerned with whether or not the instrument measures what it is supposed to measure (Ary, Jacobs, \& Razavieh, 1996; Gay, 1992). The types of validity that are important depend on the purpose the instrument is to serve. There are four types 
of validity noted by Gay: content, construct, concurrent, and predictive. For the purposes of this study content validity was important. "Content validity is determined by expert judgment. There is no formula by which it can be computed and there is no way to express it quantitatively" (p. 157).

Since the determination of content validity depends on expert judgment, a panel of three experts were asked to verify the instrument. These individuals have personal experience in the area of transferring agriculturally-related science and technology projects to third world countries. Additionally they are recognized by their peers as experts in the subject matter areas of agriculture and rural development.

Members of the expert panel were Dr. Mary Beth Bennett, Assistant Professor and Agricultural Extension Agent for Berkeley County, West Virginia Extension Service and former USAID staff member; Dr. Robert Maxwell, former dean of the WVU College of Agriculture and Forestry, and former Associate Provost of Extension and Public Service (interim appointment); Dr. Del Yoder, Resource Development Extension Specialist, Community Economic Development Department, WVU Extension Service.

The process was to submit the measurement instrument to them along with its purpose. Changes were incorporated into the instrument per their suggestions and a revised instrument was submitted to them for a second revue. The resulting instrument was used to conduct the research.

Reliability describes the dependability or trustworthiness of a measuring instrument. Gay (1992) described five types of reliability: test-retest, equivalent-forms, split-half, rationale equivalence, and scorer/rater. Since the survey instrument was attempting to measure the content of evaluations already published, the instrument was checked for scorer/rater reliability. Another rater analyzed two of the same data sets as the researcher. The estimates of inter-rater reliability were expressed as percent agreement and calculated by a point to point analysis (Gay, 1992). Ms. Robin Spitznogle, graduate assistant in the Technology Education Program, served as the second rater. The results were $77 \%$. 


\begin{abstract}
Analysis
Descriptive statistics (Gravetter \& Wallnau, 1996; Hinkle, Wiersma,\& Jurs, 1994) were used to summarize the findings of this research. Percentages were calculated to describe the frequency of occurrences in the various categories. A nominal scale was used to categorize the findings.

To aid in this analysis each project and/or its evaluation was classified according to the following categories provided by the data collection instrument. Then comparisons were made between theses groups to identify possible relationships using frequency distributions.
\end{abstract}

\title{
Findings and Conclusions
}

After completing an analysis of the data collected, the results of the analysis were presented. Following a summary of the findings, recommendations were made. 


\section{Chapter IV}

\section{DATA PRESENTATION AND ANALYSIS}

The data summarized in this chapter were to identify the type and appropriateness of the evaluations of selected agriculturally-related science and technology based projects conducted by the United States Agency for International Development between 1985 and 1995 identified in the National Science Foundation project database (Pytlik, et al., 1997). This was a descriptive research study using content analysis according to the research methodology described in Chapter Three. The study questions were: Study Question 1: What was evaluated? Study Question 2: What types of evaluations were completed and available to the public? Study Question 3: In what ways were the evaluations appropriate for determining socioeconomic impacts? Study Question 4: How might these evaluation results aid in the planning of future projects?

The data were collected with the Content Analysis Data Collection Instrument (Appendix A) and divided into sections based on the study questions. The numbers in parenthesis indicate the item number from the data collection instrument. Study Question 1: What was evaluated? covered the following information: the project identification number (1), the project dates (2), the project budget (3), the country and world region in which the project was conducted $(4,5)$, the type of agricultural technology that was being transferred by the project (6), the project status (7), was the project evaluated? (8), were all the project objectives evaluated? (15), were unexpected outcomes reported for the project? (16), were economic or efficiency indicators evaluated for the project? (17.1), was the planned project process evaluated (17.2), was the actual project process evaluated? (17.3), and were the purpose and procedures for the evaluation indicated? (17.4).

Study Question 2: : What types of evaluations were completed and available to the public? identified the following information from the data collection instrument: the evaluation identification number (9-12e), and evaluation types - formal, informal, interim, final, or impact (13.1-13.6). 
Study Question 3: In what ways were the evaluations appropriate for determining socioeconomic impacts? reported the following data: stakeholder involvement (14.1-14.4), whether or not socioeconomic impacts were included in the project objectives and goals? (18), were socioeconomic impacts evaluated (19), changes in income or living standards (19.1), changes in nutritional status (19.2), target group participation (19.3), groups identified who benefited (19.4), groups identified who did not benefit (19.5), gender equity (19.6), environmental effect (19.7), project sustainability (19.8), other socioeconomic indicators (19.919.10), and other notes (20).

The fourth study question: how might these evaluation results aid in the planning of future projects? was answered from the data already reported in the first three sections and the literature review (Chapter 2).

\section{Study Question 1: What Was Evaluated?}

The population consisted of 147 projects conducted in 55 different countries with a total budget of $\$ 2,324,974,995$. The projects were identified by USAID with a seven digit numeric number. The project dates indicated the duration of the project as well as the beginning and ending dates. The project status was reported as active (A), complete (C), or inactive (I). A list of the projects comprising the population including their associated country, world region, project dates, project status and budget were included in Tables 4.1 through 4.3 .

The projects were also categorized according to the type of technology that USAID indicated was to be transferred to the lesser developed country. Categories included agribusiness, agricultural education, finance or credit development, marketing, agricultural policy development, post production handling or storage, and production and were reported in Table 4.4. 


\section{World Region: Africa}

Sixty-eight projects were conducted in Africa (Table 4.1) involving 32 different countries with a total budget of $\$ 578,383,032$. Project dates ranged from several beginning in 1979 to those scheduled to conclude in 1999. Project status for the 68 projects conducted in Africa were reported as 17 completed, 16 active, and 35 inactive. Projects with a budget of $\$ 0$ were funded from other sources and a budget for that project was not attributed to it by the information provided by USAID.

Table 4.1

Country $\left(4^{*}\right)$, Project Identification Number ( $1 *$, Project Dates $\left(2^{*}\right)$, Project Status ( $7 *)$, Project Evaluated $\left(8^{*}\right)$ and Budget (3*) for African Projects

\begin{tabular}{|l|r|c|c|r|r|}
\hline \multicolumn{1}{|c|}{} & & & & & \\
\hline Angola & 6900268 & $93-95$ & $\mathrm{C}$ & $\mathrm{N}$ & 0 \\
\hline Botswana & 9311254 & $79-95$ & $\mathrm{~A}$ & $\mathrm{~N}$ & 326,571 \\
\hline Cameroon & 6310059 & $88-93$ & $\mathrm{I}$ & $\mathrm{Y}$ & $12,000,000$ \\
\hline Cameroon & 6310066 & $91-92$ & $\mathrm{I}$ & $\mathrm{N}$ & $15,000,000$ \\
\hline Cameroon & 6310083 & $90-92$ & $\mathrm{I}$ & $\mathrm{Y}$ & $5,500,000$ \\
\hline Cameroon & 6310085 & $92-96$ & $\mathrm{C}$ & $\mathrm{N}$ & 0 \\
\hline Central African & 6760016 & $84-88$ & $\mathrm{C}$ & $\mathrm{Y}$ & $4,306,000$ \\
Republic & & & & & \\
\hline Chad & 6770062 & $90-93$ & $\mathrm{I}$ & $\mathrm{Y}$ & $10,000,000$ \\
\hline Chad & 6770069 & $93-98$ & $\mathrm{~A}$ & $\mathrm{~N}$ & $7,000,000$ \\
\hline Comoros & 6020001 & $84-89$ & $\mathrm{C}$ & $\mathrm{Y}$ & $3,500,000$ \\
\hline Comoros & 6020002 & $89-92$ & $\mathrm{I}$ & $\mathrm{Y}$ & $3,500,000$ \\
\hline Djibouti & 6030015 & $84-86$ & $\mathrm{I}$ & $\mathrm{N}$ & $3,298,000$ \\
\hline Egypt & 2980192 & $84-87$ & $\mathrm{I}$ & $\mathrm{Y}$ & $1,268,000$ \\
\hline Egypt & 3980158 & $86-96$ & $\mathrm{~A}$ & $\mathrm{Y}$ & $1,000,000$ \\
\hline Gambia & 6350236 & $92-94$ & $\mathrm{C}$ & $\mathrm{Y}$ & $4,595,000$ \\
\hline Gambia & 9380290 & $87-91$ & $\mathrm{I}$ & $\mathrm{Y}$ & 475,000 \\
\hline Guinea & 6750212 & $84-90$ & $\mathrm{C}$ & $\mathrm{Y}$ & $1,800,000$ \\
\hline Guinea Bissau & 6570012 & $84-90$ & $\mathrm{I}$ & $\mathrm{Y}$ & $2,250,000$ \\
\hline Kenya & 6150221 & $85-91$ & $\mathrm{I}$ & $\mathrm{Y}$ & $4,026,000$ \\
\hline Kenya & 6150239 & $86-94$ & $\mathrm{~A}$ & $\mathrm{Y}$ & $10,909,000$ \\
\hline Kenya & 6150250 & $90-96$ & $\mathrm{C}$ & $\mathrm{Y}$ & $2,000,000$ \\
\hline Lesotho & 6320221 & $85-91$ & $\mathrm{I}$ & $\mathrm{Y}$ & $27,454,000$ \\
\hline
\end{tabular}




\begin{tabular}{|c|c|c|c|c|c|}
\hline 总 & 窇 & 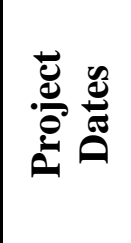 & 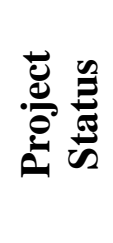 & 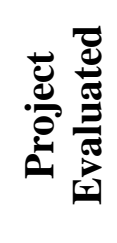 & $\underbrace{\vec{D}}_{0}$ \\
\hline Lesotho & 6320228 & $91-95$ & A & $\mathrm{Y}$ & $6,178,000$ \\
\hline Lesotho & 6320231 & 92-94 & A & $\mathrm{N}$ & $1,000,000$ \\
\hline Lesotho & 6980465 & $86-86$ & I & $\mathrm{N}$ & 166,666 \\
\hline Madagascar & 6870101 & $85-87$ & I & $\mathrm{Y}$ & $14,844,000$ \\
\hline Madagascar & 6870105 & 90-90 & I & $\mathrm{N}$ & $5,600,000$ \\
\hline Malawi & 6120215 & $85-89$ & I & $\mathrm{Y}$ & $27,500,000$ \\
\hline Malawi & 6120235 & 91-96 & A & $\mathrm{N}$ & $11,672,000$ \\
\hline Malawi & 6900268 & 93-95 & $\mathrm{C}$ & $\mathrm{N}$ & 0 \\
\hline Mali & 6880260 & 91-94 & A & $\mathrm{N}$ & $2,600,000$ \\
\hline Mali & 6880934 & $84-90$ & I & $\mathrm{Y}$ & 500,000 \\
\hline Mali & 6980465 & $86-86$ & I & $\mathrm{N}$ & 166,666 \\
\hline Mali & 9311254 & \begin{tabular}{|l}
$79-95$ \\
\end{tabular} & A & $\mathrm{N}$ & 326,571 \\
\hline Mauritania & 6820934 & $85-85$ & I & $\mathrm{Y}$ & 500,000 \\
\hline Morocco & 6080196 & $88-89$ & I & $\mathrm{Y}$ & $6,831,000$ \\
\hline Morocco & \begin{tabular}{|l|l|}
6080210 \\
\end{tabular} & \begin{tabular}{|l|}
$91-97$ \\
\end{tabular} & $\mathrm{I}$ & $\mathrm{Y}$ & $30,000,000$ \\
\hline Morocco & 6080213 & $92-95$ & A & $\mathrm{N}$ & $10,625,000$ \\
\hline Mozambique & \begin{tabular}{|l|}
6560218 \\
\end{tabular} & $90-95$ & A & $\mathrm{Y}$ & $13,500,000$ \\
\hline Mozambique & 6560223 & $92-95$ & $\mathrm{C}$ & $\mathrm{N}$ & $61,440,000$ \\
\hline Mozambique & \begin{tabular}{|l|}
6560224 \\
\end{tabular} & $92-95$ & $\mathrm{C}$ & $\mathrm{N}$ & 0 \\
\hline Mozambique & 6900268 & 93-95 & $\mathrm{C}$ & $\mathrm{N}$ & 0 \\
\hline Namibia & 6900268 & $93-95$ & $\mathrm{C}$ & & 0 \\
\hline Niger & 9311254 & $79-95$ & $\mathrm{~A}$ & $\mathrm{~N}$ & 326,571 \\
\hline Rwanda & \begin{tabular}{|c|}
6960110 \\
\end{tabular} & $84-91$ & I & $\mathrm{Y}$ & $15,700,000$ \\
\hline Senegal & \begin{tabular}{|l|}
6850269 \\
\end{tabular} & $87-89$ & I & $\mathrm{Y}$ & $20,000,000$ \\
\hline Senegal & \begin{tabular}{|l|}
6850280 \\
\end{tabular} & $85-89$ & I & $\mathrm{Y}$ & $9,500,000$ \\
\hline Senegal & \begin{tabular}{|l|}
6850283 \\
\end{tabular} & $86-92$ & $\mathrm{I}$ & $\mathrm{Y}$ & $14,000,000$ \\
\hline Senegal & 6850288 & $85-89$ & $\mathrm{~A}$ & $\mathrm{Y}$ & $12,484,000$ \\
\hline Senegal & 6850302 & $92-92$ & I & $\mathrm{N}$ & $8,000,000$ \\
\hline Senegal & 6850957 & $84-90$ & $\mathrm{I}$ & $\mathrm{Y}$ & $5,096,000$ \\
\hline Senegal & 9380290 & $87-91$ & I & $\mathrm{Y}$ & 475,000 \\
\hline Somalia & \begin{tabular}{|l|l}
6490129 \\
\end{tabular} & $87-92$ & I & $\mathrm{N}$ & $22,600,000$ \\
\hline Sudan & 6500082 & $87-90$ & $\mathrm{I}$ & $\mathrm{N}$ & $8,000,000$ \\
\hline Sudan & 9311254 & $79-95$ & $\mathrm{~A}$ & $\mathrm{~N}$ & 326,571 \\
\hline Swaziland & \begin{tabular}{|l}
9365826 \\
\end{tabular} & $85-92$ & $\mathrm{I}$ & $\mathrm{Y}$ & $1,823,750$ \\
\hline Swaziland & 6980465 & $86-86$ & $\mathrm{I}$ & $\mathrm{N}$ & 166,666 \\
\hline Tanzania & 6900268 & 93-95 & $\mathrm{C}$ & $\mathrm{N}$ & 0 \\
\hline Tunisia & 6640343 & $87-90$ & I & $\mathrm{Y}$ & $5,501,000$ \\
\hline
\end{tabular}




\begin{tabular}{|c|c|c|c|c|c|}
\hline 葛 & 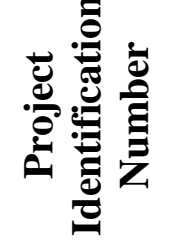 & 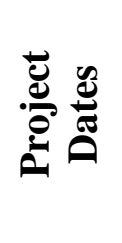 & 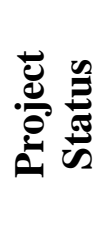 & 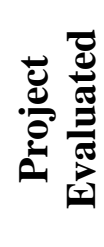 & 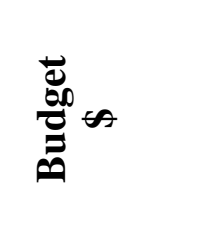 \\
\hline Uganda & 6170106 & $85-89$ & $\mathrm{C}$ & $\mathrm{N}$ & 0 \\
\hline Uganda & 6170114 & $92-92$ & $\mathrm{C}$ & $\mathrm{Y}$ & $59,500,000$ \\
\hline Uganda & 6170125 & 94-99 & A & $\mathrm{N}$ & $5,250,000$ \\
\hline Zaire & 6600119 & $86-90$ & I & Y & $19,000,000$ \\
\hline Zaire & 6600124 & $89-91$ & I & Y & $25,000,000$ \\
\hline Zambia & 6110207 & $87-92$ & I & $\mathrm{Y}$ & $19,876,000$ \\
\hline Zambia & 6110214 & $88-89$ & I & $\mathrm{Y}$ & $12,100,000$ \\
\hline Zambia & 6900268 & $93-95$ & $\mathrm{C}$ & $\mathrm{N}$ & 0 \\
\hline Zimbabwe & 6900268 & 93-95 & $\mathrm{C}$ & $\mathrm{N}$ & 0 \\
\hline
\end{tabular}

Note. $\mathrm{A}=$ active; $\mathrm{I}=$ inactive; $\mathrm{C}=$ complete.

*This number references the item number in the Data Collection Instrument in Appendix A.

\section{World Region: Asia}

Thirty projects were conducted in Asia (Table 4.2) involving 9 different countries with a total budget of $\$ 959,527,571$. Project dates ranged from several beginning in 1979 to those scheduled to conclude in 1997. Project status for the 30 projects conducted in Asia were reported as 5 completed, 9 active, and 16 inactive.

Table 4.2

Country $(4 *)$, Project Identification Number $(1 *)$, Project Dates $(2 *)$, Project Status $\left(7^{*}\right)$, Project Evaluated $\left(8^{*}\right)$ and Budget $\left(3^{*}\right)$ for Asian Projects

\begin{tabular}{|c|c|c|c|c|c|}
\hline 总 & 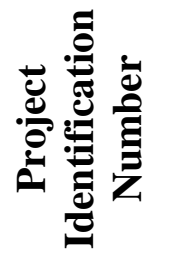 & 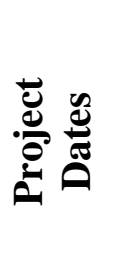 & 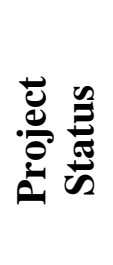 & 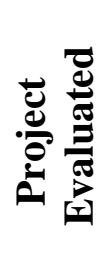 & 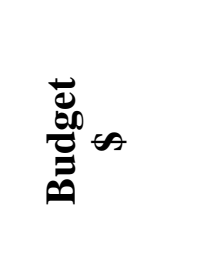 \\
\hline India & 3860489 & $84-92$ & $\mathrm{C}$ & $\mathrm{Y}$ & $23,581,000$ \\
\hline India & 3860490 & $84-85$ & $\mathrm{C}$ & $\mathrm{Y}$ & $38,603,000$ \\
\hline India & 3860495 & $85-89$ & $\mathrm{C}$ & $\mathrm{Y}$ & $113,770,000$ \\
\hline India & 9311254 & $79-95$ & $\mathrm{~A}$ & $\mathrm{~N}$ & 326,571 \\
\hline Indonesia & 4970302 & $80-93$ & $\mathrm{I}$ & $\mathrm{Y}$ & $28,330,000$ \\
\hline Indonesia & 4970304 & $83-86$ & $\mathrm{I}$ & $\mathrm{Y}$ & $7,400,000$ \\
\hline
\end{tabular}




\begin{tabular}{|c|c|c|c|c|c|}
\hline$\vec{E}$ & 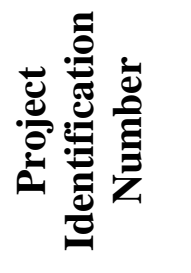 & 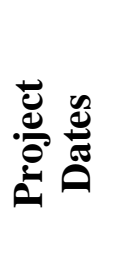 & 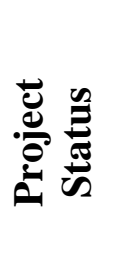 & 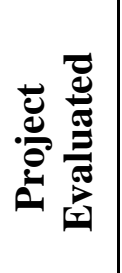 & 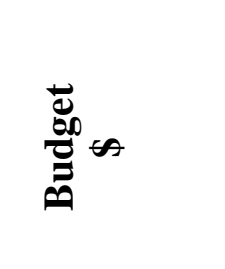 \\
\hline Indonesia & 4970311 & $84-93$ & $\mathrm{I}$ & Y & $34,706,000$ \\
\hline Indonesia & 4970330 & $81-84$ & $\mathrm{C}$ & Y & $5,000,000$ \\
\hline Indonesia & 4970342 & $84-85$ & I & Y & $9,000,000$ \\
\hline Indonesia & 4970347 & $85-93$ & I & Y & $81,249,000$ \\
\hline Indonesia & 4970352 & $86-92$ & I & Y & $2,810,000$ \\
\hline Indonesia & 4970357 & $87-96$ & A & Y & $200,000,000$ \\
\hline Indonesia & 4970368 & $91-97$ & A & Y & $40,000,000$ \\
\hline Indonesia & 4970378 & 93-97 & $\mathrm{C}$ & $\mathrm{N}$ & 0 \\
\hline Jordan & 2780264 & $85-93$ & I & $\mathrm{N}$ & $25,275,000$ \\
\hline Jordan & 2780274 & $88-93$ & I & Y & $8,300,000$ \\
\hline Nepal & 3670148 & $85-90$ & I & $\mathrm{Y}$ & $4,100,000$ \\
\hline Nepal & 3670153 & $85-94$ & A & Y & $18,000,000$ \\
\hline Nepal & 3670155 & $87-94$ & A & Y & $37,600,000$ \\
\hline Nepal & 3670156 & $86-90$ & I & $\mathrm{N}$ & $4,820,000$ \\
\hline Nepal & 3670158 & $88-93$ & I & $\mathrm{Y}$ & $16,000,000$ \\
\hline Pakistan & 3910489 & $84-90$ & I & $\mathrm{Y}$ & $64,500,000$ \\
\hline Pakistan & 3910491 & $84-88$ & I & $\mathrm{Y}$ & $35,000,000$ \\
\hline Philippines & 9364146 & $85-95$ & A & $\mathrm{Y}$ & $2,807,000$ \\
\hline Sri Lanka & 3830080 & $86-92$ & I & $\mathrm{Y}$ & $25,500,000$ \\
\hline Sri Lanka & 3830083 & $86-92$ & I & $\mathrm{Y}$ & $13,200,000$ \\
\hline Sri Lanka & 3830086 & $87-94$ & A & $\mathrm{Y}$ & $37,000,000$ \\
\hline Sri Lanka & 3830111 & $92-97$ & A & Y & $20,650,000$ \\
\hline Thailand & 4930337 & $84-90$ & A & $\mathrm{Y}$ & $22,000,000$ \\
\hline Yemen & 2790084 & $89-90$ & I & $\mathrm{N}$ & $40,000,000$ \\
\hline
\end{tabular}

Note. $\mathrm{A}=$ active; $\mathrm{I}=$ inactive; $\mathrm{C}=$ complete.

*This number references the item number in the Data Collection Instrument in Appendix A.

\section{World Region: Latin America and Caribbean}

Forty-nine projects were conducted in Latin America and the Caribbean (Table 4.3) involving 14 different countries with a total budget of $\$ 787,064,392$. Project dates ranged from several beginning in 1979 to those scheduled to conclude in 1997. Project status for the 49 projects conducted in Latin America and the Caribbean were reported as 8 completed, 21 active, and 20 inactive. 
Table 4.3

Country (4*), Project Identification Number $\left(1^{*}\right)$, Project Dates $\left(2^{*}\right)$, Project Status ( $7 *)$, Project Evaluated $\left(8^{*}\right)$ and Budget $\left(3^{*}\right)$ for Projects Conducted in Latin America and the Caribbean

\begin{tabular}{|c|c|c|c|c|c|}
\hline 总 & 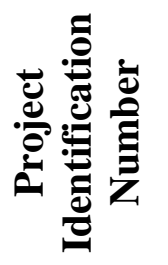 & 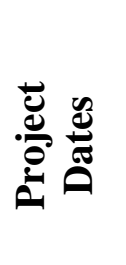 & 异氙 & . & 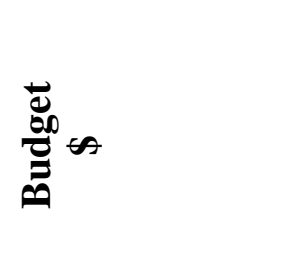 \\
\hline Belize & 5050008 & $85-93$ & $\mathrm{I}$ & $\mathrm{Y}$ & $16,200,000$ \\
\hline Belize & 5050023 & $84-85$ & $\mathrm{C}$ & $\mathrm{Y}$ & 615,000 \\
\hline Belize & 5050036 & $86-86$ & $\mathrm{I}$ & $\mathrm{Y}$ & 600,000 \\
\hline Bolivia & 5110589 & $86-92$ & $\mathrm{I}$ & $Y$ & $12,940,000$ \\
\hline Bolivia & 5110621 & 93-99 & $\mathrm{A}$ & $\mathrm{N}$ & $15,000,000$ \\
\hline Columbia & 9311254 & $79-95$ & $\mathrm{~A}$ & $\mathrm{~N}$ & 326,571 \\
\hline Costa Rica & 5150224 & $85-85$ & $\mathrm{I}$ & $\mathrm{N}$ & 71,000 \\
\hline Costa Rica & 5150227 & $85-86$ & $\mathrm{C}$ & $\mathrm{Y}$ & 800,000 \\
\hline Costa Rica & 5150243 & $88-90$ & $\mathrm{I}$ & $\mathrm{Y}$ & $15,000,000$ \\
\hline Costa Rica & 5150263 & $93-96$ & A & $\mathrm{N}$ & $2,000,000$ \\
\hline Costa Rica & 9364146 & $85-95$ & A & $\mathrm{Y}$ & $2,807,000$ \\
\hline $\begin{array}{l}\text { Dominican } \\
\text { Republic } \\
\end{array}$ & 5170156 & $84-88$ & I & $\mathrm{Y}$ & $1,250,000$ \\
\hline $\begin{array}{l}\text { Dominican } \\
\text { Republic } \\
\end{array}$ & 5170159 & $83-92$ & $\mathrm{I}$ & $\mathrm{Y}$ & $12,849,000$ \\
\hline $\begin{array}{l}\text { Dominican } \\
\text { Republic }\end{array}$ & 5170173 & $84-85$ & I & $\mathrm{N}$ & $8,000,000$ \\
\hline $\begin{array}{l}\text { Dominican } \\
\text { Republic }\end{array}$ & 5170186 & $85-90$ & I & $\mathrm{Y}$ & $28,300,000$ \\
\hline $\begin{array}{l}\text { Dominican } \\
\text { Republic } \\
\end{array}$ & 5170214 & $87-89$ & I & $\mathrm{Y}$ & $21,920,000$ \\
\hline Ecuador & 5180019 & 84-94 & A & $\mathrm{Y}$ & $22,375,000$ \\
\hline Ecuador & 5180047 & $84-87$ & $\mathrm{I}$ & $\mathrm{N}$ & 350,000 \\
\hline Ecuador & 5180051 & $85-94$ & A & $\mathrm{Y}$ & $23,795,000$ \\
\hline Ecuador & 5180068 & $87-94$ & A & $\mathrm{N}$ & $14,000,000$ \\
\hline Ecuador & 5180092 & $90-90$ & $\mathrm{C}$ & $\mathrm{N}$ & 241,000 \\
\hline Ecuador & 9365826 & $85-92$ & I & $\mathrm{Y}$ & $1,823,750$ \\
\hline El Salvador & 5190307 & $86-93$ & $\mathrm{I}$ & $\mathrm{Y}$ & $100,000,000$ \\
\hline El Salvador & 5190327 & $87-94$ & A & $\mathrm{Y}$ & $58,534,000$ \\
\hline El Salvador & 5190362 & $91-97$ & $\mathrm{~A}$ & $\mathrm{~N}$ & $24,000,000$ \\
\hline El Salvador & 5190389 & $93-97$ & $\mathrm{C}$ & $\mathrm{N}$ & 0 \\
\hline El Salvador & 5190392 & $91-95$ & A & $\mathrm{N}$ & $18,000,000$ \\
\hline Guatemala & 5200276 & $85-89$ & $\mathrm{I}$ & $Y$ & $13,500,000$ \\
\hline
\end{tabular}




\begin{tabular}{|l|r|r|c|r|r|}
\hline & & & & \\
& & & & & \\
& & & & & \\
\hline Guatemala & 5200330 & $84-84$ & $\mathrm{C}$ & $\mathrm{Y}$ & $1,000,000$ \\
\hline Guatemala & 5200392 & $91-95$ & $\mathrm{C}$ & $\mathrm{N}$ & 0 \\
\hline Guyana & 5040104 & $93-96$ & $\mathrm{~A}$ & $\mathrm{~N}$ & 550,000 \\
\hline Haiti & 5210201 & $90-96$ & $\mathrm{C}$ & $\mathrm{N}$ & $2,000,000$ \\
\hline Haiti & 5210216 & $90-96$ & $\mathrm{~A}$ & $\mathrm{Y}$ & $12,440,000$ \\
\hline Honduras & 5220207 & $84-94$ & $\mathrm{~A}$ & $\mathrm{Y}$ & $54,914,000$ \\
\hline Honduras & 5220246 & $87-97$ & $\mathrm{~A}$ & $\mathrm{Y}$ & $40,000,000$ \\
\hline Honduras & 5220249 & $84-94$ & $\mathrm{~A}$ & $\mathrm{Y}$ & $37,350,000$ \\
\hline Honduras & 5220252 & $85-95$ & $\mathrm{~A}$ & $\mathrm{Y}$ & $28,500,000$ \\
\hline Honduras & 5220268 & $86-94$ & $\mathrm{~A}$ & $\mathrm{Y}$ & $33,790,000$ \\
\hline Honduras & 5220292 & $88-97$ & $\mathrm{~A}$ & $\mathrm{Y}$ & $54,000,000$ \\
\hline Honduras & 9311254 & $79-95$ & $\mathrm{~A}$ & $\mathrm{~N}$ & 326,571 \\
\hline Honduras & 9365826 & $85-92$ & $\mathrm{I}$ & $\mathrm{Y}$ & $1,823,000$ \\
\hline Jamaica & 5230101 & $87-97$ & $\mathrm{~A}$ & $\mathrm{Y}$ & $20,000,000$ \\
\hline Panama & 5250222 & $84-89$ & $\mathrm{I}$ & $\mathrm{N}$ & $7,306,000$ \\
\hline Peru & 5270282 & $87-93$ & $\mathrm{I}$ & $\mathrm{Y}$ & $45,083,000$ \\
\hline Peru & 5270293 & $85-87$ & $\mathrm{C}$ & $\mathrm{Y}$ & 750,000 \\
\hline Peru & 5270321 & $88-88$ & $\mathrm{I}$ & $\mathrm{N}$ & $3,910,000$ \\
\hline Peru & 5270349 & $91-97$ & $\mathrm{~A}$ & $\mathrm{Y}$ & $25,500,000$ \\
\hline Peru & 5270372 & $93-93$ & $\mathrm{I}$ & $\mathrm{N}$ & 700,000 \\
\hline Peru & 9365826 & $85-92$ & $\mathrm{I}$ & $\mathrm{Y}$ & $1,823,750$ \\
\hline
\end{tabular}

Note. $\mathrm{A}=$ active; $\mathrm{I}=$ inactive; $\mathrm{C}=$ complete.

*This number references the item number in the Data Collection Instrument in Appendix A.

\section{Agricultural Technologies Transferred}

Each project was categorized by the type of agricultural technology that was being transferred according to the project goals (Table 4.4). Six categories were identified: business, education, marketing, policy, post production (included storage and post harvest handling), and production. Production type technologies (82) accounted for 55.8\% of the project activities. Post production technologies (2) accounted for only $1.4 \%$ of the projects. Business (10.2\%), education (9.5\%), marketing (10.9\%), and policy (12.2\%) comprised $42.8 \%$ of the total projects in nearly equal proportions. The percentage of 
projects evaluated ranged from $50 \%$ for post production projects to a high of $83 \%$ for projects dealing with agricultural policy.

Table 4.4

Types of Technology Being Transferred $\left(6^{*}\right)$

\begin{tabular}{|c|c|c|}
\hline \hline Type of Technology & Number of Projects (\%) & Percent Evaluated \\
\hline Business & $15(10.2 \%)$ & 66.7 \\
\hline Education & $14(9.5 \%)$ & 78.6 \\
\hline Marketing & $16(10.9 \%)$ & 62.5 \\
\hline Policy & $18(12.2 \%)$ & 83.3 \\
\hline Post Production & $2(1.4 \%)$ & 50.0 \\
\hline Production & $82(55.8 \%)$ & 56.1 \\
\hline Totals & $147(100 \%)$ & - \\
\hline
\end{tabular}

*This number references the item number in the Data Collection Instrument in Appendix A

When possible the category of production was further subcategorized into four categories: agronomic, animal, aquaculture, and forestry and a fifth category of not identifiable. The agronomic category included any type of plant propagation and production except trees. The animal category included mammals, fowl, and fishing. Aquaculture included the raising of fish and other aquatic animals such as crayfish and shrimp. The forestry subcategory included the production of trees for timber, pulp and conservation purposes.

Two projects $(2.4 \%)$ involving production type technologies could not be identified as to a specific type of production. Fifty-five of the production type development projects or $67.1 \%$ involved agronomic production type technologies. Another 14 projects (17.1\%) involved forestry. The remaining projects (13.4\%) involved animals or aquaculture.

\section{Projects With or Without Evaluations}

Of the total population of 147 projects, 53 or $36.1 \%$ were not evaluated (Table 4.5). The remaining 94 projects had at least one evaluation. Africa had 30 projects not evaluated, while Asia had only 5 projects not evaluated. Table 4.1, Table 4.2, and Table 4.3 indicate which projects were evaluated and which were not evaluated. 
Table 4.5

Comparison of Projects Evaluated by World Region ( $\left.5^{*}\right)$

\begin{tabular}{|c|c|c|c|}
\hline \hline $\begin{array}{c}\text { World } \\
\text { Region }\end{array}$ & $\begin{array}{c}\text { Projects } \\
\text { Evaluated }\end{array}$ & $\begin{array}{c}\text { Projects Not } \\
\text { Evaluated }\end{array}$ & $\begin{array}{c}\text { Percent } \\
\text { Projects } \\
\text { Evaluated }\end{array}$ \\
\hline Africa & 38 & 30 & 55.9 \\
\hline Asia & 25 & 5 & 83.3 \\
\hline LAC & 31 & 18 & 63.3 \\
\hline Totals & 94 & 53 & -- \\
\hline
\end{tabular}

*This number references the item number in the Data Collection Instrument in Appendix A.

\section{Projects with Evaluations}

Tables 4.6, 4.7, 4.8 summarize the results, by world regions, of reviewing each evaluation to determine whether or not the following items were included in the evaluation. (1) All of the project's objectives were evaluated; (2) The evaluators noted any unexpected outcomes from the project; (3) Economic or efficiency indicators were evaluated; (4) The planned project process was evaluated; (5) The actual project process was evaluated; And (6) the evaluation's purpose and procedures were reported.

\section{Project Objectives}

Eighty projects had all of their objectives evaluated; the remaining fourteen projects did not. Six of the projects $(3830111,5050008,5150227,5180019,6110207$, 6350236) did not provide enough information to make a determination. The evaluation for project 5220249 discussed all of the planned project objectives but because of the lack of baseline data no evaluation was attempted. Project 4970302 evaluated only those project goals that USAID suspected might have a difficult time accomplishing the end goals for the project. In three of the projects $(5110621,5170156,6110214)$ increased income was a goal but not evaluated. Project 5150243 evaluated only the project goals relating to environmental sustainability. Increased food production (project 3860490) was not evaluated. Only the agricultural cooperative portion of project 520276 was evaluated, while the other two components involving agricultural credit and exports were not evaluated. 


\section{Unexpected Outcomes}

Seventy-six of the projects evaluated did not list any unexpected outcomes, while 18 project evaluations noted at least one unexpected outcome derived from the project activities. Three of the projects $(2780274,3670148,6850280)$ noted negative outcomes. Negative outcomes included: (1) not taking into account pesticide certification, (2) political problems arising, and (3) the reasons for failure of the project was from unexpected sources. Unexpected positive outcomes were reported in the other 15 projects. The most frequently occurring positive outcome was having others adopt the technology who were not part of the targeted population.

\section{Economic or Efficiency Indicators}

Only 22 of the 94 projects with evaluations did not have any economic or efficiency indicators reported. The other 72 projects had some type of economic or efficiency indicators evaluated. These included acres, number planted, pounds harvested as well as economic indicators such as selling price, price per pound, and number of employed people as a result of the project.

\section{Planned and Actual Process Evaluated}

Fifteen of the 94 projects did not evaluate the planned process for carrying out the goals of the project. All but 14 of the projects were evaluated for the process they actually used.

\section{Evaluation Purpose and Procedures}

The purpose for the project's evaluation and the methodology used by the evaluators was reported for 84 of the 94 projects.

\section{Africa.}

Thirty-eight projects conducted in Africa had at least one evaluation conducted and reported. Evaluators attempted to evaluate all of the indicated project objectives for 35 of these projects. In addition unexpected outcomes of the project were noted for four of these projects (Table 4.6). For the unexpected outcomes reported three noted positive outcomes and one reported negative outcomes. Economic or efficiency indicators were reported for 34 projects. Thirty-two projects reviewed both the project's planned and 
actual process. The evaluator's purpose and procedures were not reported for five projects.

Table 4.6

Project Identification $(1 *)$, Project Objectives $\left(15^{*}\right)$, Unexpected Outcomes $\left(16^{*}\right)$, Economic and Efficiency Indicators (17.1*), Planned Process (17.2*), Actual Process $(17.3 *)$, and Evaluation Purposes and Procedures (17.4*) Noted for African Projects

\begin{tabular}{|c|c|c|c|c|c|c|}
\hline 㞭 & 畜 & 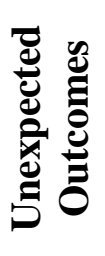 & 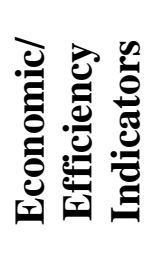 & 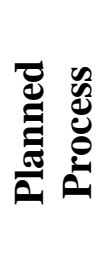 & 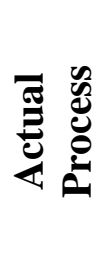 & 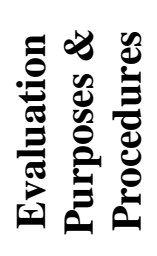 \\
\hline 2980192 & $\mathrm{y}$ & $\mathrm{n}$ & $\mathrm{y}$ & $\mathrm{y}$ & $\mathrm{y}$ & $\mathrm{y}$ \\
\hline 3980158 & $\mathrm{y}$ & $\mathrm{n}$ & $\mathrm{n}$ & $\mathrm{y}$ & $\mathrm{y}$ & $\mathrm{y}$ \\
\hline 6020001 & $\mathrm{y}$ & $\mathrm{n}$ & $\mathrm{y}$ & $\mathrm{n}$ & $\mathrm{n}$ & $\mathrm{n}$ \\
\hline 6020002 & $\mathrm{y}$ & $y^{10}$ & $\mathrm{y}$ & $\mathrm{y}$ & $\mathrm{y}$ & $\mathrm{y}$ \\
\hline 6080196 & $\mathrm{y}$ & $\mathrm{n}$ & $\mathrm{y}$ & $\mathrm{y}$ & $\mathrm{y}$ & $\mathrm{y}$ \\
\hline 6080210 & $\mathrm{y}$ & $\mathrm{n}$ & $y$ & $y$ & $\mathrm{y}$ & $\mathrm{y}$ \\
\hline 6110207 & $\mathrm{n}^{7}$ & $\mathrm{n}$ & $\mathrm{n}$ & $\mathrm{y}$ & $\mathrm{y}$ & $\mathrm{y}$ \\
\hline $6110214^{1}$ & $\mathrm{n}^{8}$ & $\mathrm{n}$ & $\mathrm{y}$ & $\mathrm{y}$ & $\mathrm{y}$ & $\mathrm{y}$ \\
\hline 6120215 & $\mathrm{y}$ & $\mathrm{n}$ & $\mathrm{y}$ & $\mathrm{y}$ & $\mathrm{y}$ & $\mathrm{y}$ \\
\hline 6150221 & $\mathrm{y}$ & $\mathrm{n}$ & $\mathrm{y}$ & $\mathrm{y}$ & $\mathrm{y}$ & $\mathrm{y}$ \\
\hline 6150239 & $\mathrm{y}$ & $\mathrm{n}$ & $\mathrm{y}$ & $\mathrm{y}$ & $\mathrm{y}$ & $\mathrm{y}$ \\
\hline 6150250 & $\mathrm{y}$ & $\mathrm{n}$ & $\mathrm{y}$ & $\mathrm{y}$ & $\mathrm{y}$ & $\mathrm{y}$ \\
\hline 6170114 & $\mathrm{y}$ & $\mathrm{n}$ & $\mathrm{y}$ & $\mathrm{y}$ & $\mathrm{y}$ & $\mathrm{y}$ \\
\hline 6310059 & $\mathrm{y}$ & $\mathrm{n}$ & $\mathrm{y}$ & $\mathrm{y}$ & $\mathrm{y}$ & $\mathrm{y}$ \\
\hline $6310083^{2}$ & $\mathrm{y}$ & $\mathrm{n}$ & $\mathrm{y}$ & $\mathrm{y}$ & $\mathrm{y}$ & $\mathrm{y}$ \\
\hline 6320221 & $\mathrm{y}$ & $\mathrm{n}$ & $\mathrm{n}$ & $\mathrm{n}$ & $\mathrm{n}$ & $\mathrm{n}$ \\
\hline $6320228^{3}$ & $\mathrm{y}$ & $\mathrm{n}$ & $\mathrm{y}$ & $\mathrm{y}$ & $\mathrm{y}$ & $\mathrm{y}$ \\
\hline 6350236 & $n^{9}$ & $\mathrm{n}$ & $\mathrm{n}$ & $\mathrm{y}$ & $\mathrm{y}$ & $\mathrm{n}$ \\
\hline 6560218 & $\mathrm{y}$ & $\mathrm{n}$ & $\mathrm{y}$ & $\mathrm{y}$ & $\mathrm{y}$ & $\mathrm{y}$ \\
\hline 6570012 & $\mathrm{y}$ & $\mathrm{n}$ & $\mathrm{y}$ & $\mathrm{y}$ & $\mathrm{y}$ & $\mathrm{y}$ \\
\hline 6600119 & $\mathrm{y}$ & $\mathrm{n}$ & $\mathrm{y}$ & $\mathrm{y}$ & $\mathrm{y}$ & $\mathrm{y}$ \\
\hline 6600124 & $\mathrm{y}$ & $\mathrm{n}$ & $\mathrm{y}$ & $\mathrm{y}$ & $\mathrm{y}$ & $\mathrm{y}$ \\
\hline 6640343 & $\mathrm{y}$ & $\mathrm{n}$ & $\mathrm{y}$ & $\mathrm{y}$ & $\mathrm{y}$ & $\mathrm{y}$ \\
\hline 6750212 & $\mathrm{y}$ & $\mathrm{n}$ & $\mathrm{y}$ & $\mathrm{y}$ & $\mathrm{y}$ & $\mathrm{y}$ \\
\hline 6760016 & $\mathrm{y}$ & $\mathrm{n}$ & $\mathrm{y}$ & $\mathrm{y}$ & $\mathrm{y}$ & $\mathrm{y}$ \\
\hline 6770062 & $\mathrm{y}$ & $\mathrm{n}$ & $\mathrm{y}$ & $\mathrm{y}$ & $\mathrm{y}$ & $\mathrm{y}$ \\
\hline 6820934 & $\mathrm{y}$ & $y^{11}$ & $\mathrm{y}$ & $\mathrm{y}$ & $\mathrm{y}$ & $\mathrm{y}$ \\
\hline 6850269 & $\mathrm{y}$ & $\mathrm{n}$ & $\mathrm{y}$ & $\mathrm{y}$ & $\mathrm{y}$ & $\mathrm{y}$ \\
\hline $6850280^{4}$ & $\mathrm{y}$ & $y^{12}$ & $\mathrm{y}$ & $\mathrm{y}$ & $\mathrm{y}$ & $\mathrm{y}$ \\
\hline 6850283 & $\mathrm{y}$ & $\mathrm{n}$ & $\mathrm{y}$ & $\mathrm{y}$ & $\mathrm{y}$ & $\mathrm{y}$ \\
\hline 6850288 & $\mathrm{y}$ & $\mathrm{n}$ & $\mathrm{y}$ & $\mathrm{n}$ & $\mathrm{n}$ & $\mathrm{n}$ \\
\hline
\end{tabular}




\begin{tabular}{|c|c|c|c|c|c|c|}
\hline 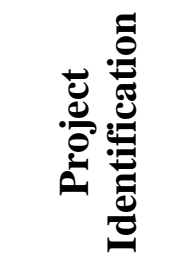 & 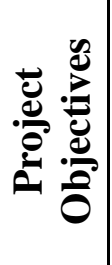 & 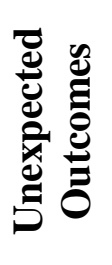 & 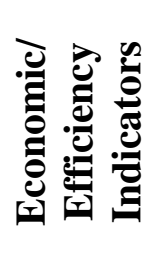 & 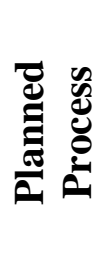 & 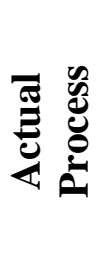 & 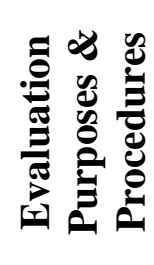 \\
\hline $6850957^{5}$ & $\mathrm{y}$ & $\mathrm{n}$ & $\mathrm{y}$ & $\mathrm{n}$ & $\mathrm{n}$ & $\mathrm{n}$ \\
\hline 6870101 & $\mathrm{y}$ & $\mathrm{n}$ & $\mathrm{y}$ & $\mathrm{n}$ & $\mathrm{n}$ & $\mathrm{y}$ \\
\hline $6880934^{6}$ & $\mathrm{y}$ & $\mathrm{n}$ & $\mathrm{y}$ & $\mathrm{n}$ & $\mathrm{n}$ & $\mathrm{y}$ \\
\hline $6960110^{7}$ & $\mathrm{y}$ & $\mathrm{n}$ & $\mathrm{y}$ & $\mathrm{y}$ & $\mathrm{y}$ & $\mathrm{y}$ \\
\hline $\begin{array}{c}9365826 \\
\text { Swaziland }\end{array}$ & $\mathrm{y}$ & $y^{13}$ & $\mathrm{y}$ & $\mathrm{y}$ & $\mathrm{y}$ & $\mathrm{y}$ \\
\hline $\begin{array}{c}9380290 \\
\text { Senegal }\end{array}$ & $\mathrm{y}$ & $\mathrm{n}$ & $\mathrm{y}$ & $\mathrm{y}$ & $\mathrm{y}$ & $\mathrm{y}$ \\
\hline $\begin{array}{c}9380290 \\
\text { Gambia }\end{array}$ & $\mathrm{y}$ & $\mathrm{n}$ & $\mathrm{y}$ & $\mathrm{y}$ & $\mathrm{y}$ & $\mathrm{y}$ \\
\hline $\begin{array}{c}\text { Total } \\
\text { Numbers }\end{array}$ & $\begin{array}{c}35 \mathrm{y} \\
3 \mathrm{n}\end{array}$ & $\begin{array}{c}4 \mathrm{y} \\
34 \mathrm{n}\end{array}$ & $\begin{array}{c}34 \mathrm{y} \\
4 \mathrm{n}\end{array}$ & $\begin{array}{c}32 \mathrm{y} \\
6 \mathrm{n}\end{array}$ & $\begin{array}{c}32 y \\
6 n \\
\end{array}$ & $\begin{array}{c}33 \mathrm{y} \\
5 \mathrm{n}\end{array}$ \\
\hline
\end{tabular}

*This number references the item number in the Data Collection Instrument in Appendix A.

${ }^{1}$ Baseline data not gathered properly. Evaluators used baseline study and did not attempt, to gather their own data.

${ }^{2}$ Lack of a project logframe was noted by evaluators.

${ }^{3}$ Project design was not based on realistic assumptions.

${ }^{4}$ Project design was not based on realistic assumptions.

${ }^{5}$ Only purpose of report was to determine long term sustainability.

${ }^{6}$ Evaluators used rapid reconnaissance survey technique and included farmers from within the project as well as outside of the project.

${ }^{7}$ Report did not indicate whether or not all objectives had been evaluated.

${ }^{8}$ Income objective not addressed in the evaluation.

${ }^{9}$ Evaluators did not attempt to evaluate project objectives.

${ }^{10}$ Thirty percent of the farmers outside of the project area have adopted the bulk of the project's technology package.

${ }^{11}$ Two outcomes noted: (1) Neighbors copied technology being introduced by the project, and (2) the extension service took an interest in the project and helped with the experiments.

12 Evaluators noted that the reasons for the project's failures were unexpected.

${ }^{13}$ Because of radio broadcasts about the project, 13 other communities asked for help. Asia.

Twenty-five projects conducted in Asia had at least one evaluation conducted and reported. Evaluators attempted to evaluate all of the indicated project objectives for 22 of these projects. In addition, unexpected outcomes of the project were noted for 8 of these projects (Table 4.7). For the unexpected outcomes reported, six noted positive outcomes 
and two noted negative outcomes. Economic or efficiency indicators were reported for 15 projects. While evaluators reviewed planned process for 23 projects, twenty-four projects were reviewed for their actual process. Also, twenty-three projects had evaluations which indicated the purpose of the evaluation and the procedures used by the evaluators.

Table 4.7

Project Identification $(1 *)$, Project Objectives $\left(15^{*}\right)$, Unexpected Outcomes $\left(16^{*}\right)$, Economic and Efficiency Indicators (17.1*), Planned Process (17.2*), Actual Process $(17.3 *)$, and Evaluation Purposes and Procedures (17.4*) Noted for Asian Projects

\begin{tabular}{|c|c|c|c|c|c|c|}
\hline م & 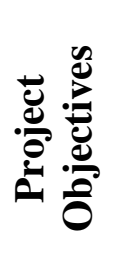 & 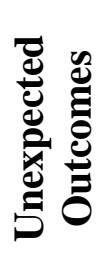 & 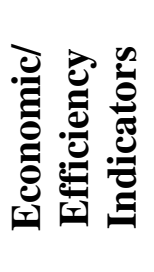 & 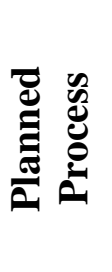 & 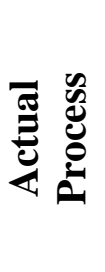 & 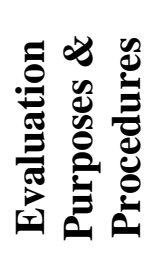 \\
\hline 2780274 & $\mathrm{y}$ & $y^{5}$ & $\mathrm{y}$ & $\mathrm{y}$ & $\mathrm{y}$ & $y^{1}$ \\
\hline 3670148 & $\mathrm{y}$ & $y^{6}$ & $\mathrm{n}$ & $\mathrm{n}$ & $\mathrm{n}$ & $\mathrm{n}$ \\
\hline 3670153 & $\mathrm{y}$ & $\mathrm{n}$ & $\mathrm{y}$ & $\mathrm{n}$ & $\mathrm{y}$ & $\mathrm{y}$ \\
\hline 3670155 & $\mathrm{y}$ & $\mathrm{n}$ & $\mathrm{y}$ & $\mathrm{y}$ & $\mathrm{y}$ & $\mathrm{y}$ \\
\hline 3670158 & $\mathrm{y}$ & $\mathrm{n}$ & $\mathrm{n}$ & $\mathrm{y}$ & $\mathrm{y}$ & $\mathrm{y}$ \\
\hline 3830080 & $\mathrm{y}$ & $y^{7}$ & $\mathrm{y}$ & $\mathrm{y}$ & $\mathrm{y}$ & $\mathrm{n}$ \\
\hline 3830083 & $\mathrm{y}$ & $y^{8}$ & $\mathrm{n}$ & $\mathrm{y}$ & $y$ & $y$ \\
\hline 3830086 & $\mathrm{y}$ & $\mathrm{y}^{9}$ & $\mathrm{y}$ & $\mathrm{y}$ & $\mathrm{y}$ & $\mathrm{y}$ \\
\hline 3830111 & $\mathrm{n}^{2}$ & $\mathrm{n}$ & $\mathrm{y}$ & $\mathrm{y}$ & $\mathrm{y}$ & $\mathrm{y}$ \\
\hline 3860489 & $\mathrm{y}$ & $\mathrm{n}$ & $\mathrm{y}$ & $\mathrm{y}$ & $\mathrm{y}$ & $\mathrm{y}$ \\
\hline 3860490 & $n^{3}$ & $y^{10}$ & $\mathrm{y}$ & $\mathrm{y}$ & $\mathrm{y}$ & $\mathrm{y}$ \\
\hline 3860495 & $\mathrm{y}$ & $\mathrm{n}$ & $\mathrm{y}$ & $\mathrm{y}$ & $\mathrm{y}$ & $\mathrm{y}$ \\
\hline 3910489 & $\mathrm{y}$ & $\mathrm{n}$ & $\mathrm{n}$ & $\mathrm{y}$ & $\mathrm{y}$ & $\mathrm{y}$ \\
\hline 3910491 & $\mathrm{y}$ & $\mathrm{n}$ & $\mathrm{y}$ & $\mathrm{y}$ & $\mathrm{y}$ & $\mathrm{y}$ \\
\hline 4930337 & $\mathrm{y}$ & $\mathrm{n}$ & $\mathrm{y}$ & $\mathrm{y}$ & $\mathrm{y}$ & $\mathrm{y}$ \\
\hline 4970302 & $n^{4}$ & $\mathrm{n}$ & $\mathrm{n}$ & $\mathrm{y}$ & $\mathrm{y}$ & $\mathrm{y}$ \\
\hline 4970304 & $\mathrm{y}$ & $\mathrm{n}$ & $\mathrm{y}$ & $\mathrm{y}$ & $\mathrm{y}$ & $\mathrm{y}$ \\
\hline 4970311 & $\mathrm{y}$ & $\mathrm{n}$ & $\mathrm{n}$ & $\mathrm{y}$ & $\mathrm{y}$ & $\mathrm{y}$ \\
\hline 4970330 & $\mathrm{y}$ & $\mathrm{n}$ & $\mathrm{n}$ & $\mathrm{y}$ & $\mathrm{y}$ & $\mathrm{y}$ \\
\hline 4970342 & $\mathrm{y}$ & $\mathrm{n}$ & $\mathrm{n}$ & $\mathrm{y}$ & $\mathrm{y}$ & $\mathrm{y}$ \\
\hline 4970347 & $\mathrm{y}$ & $y^{11}$ & $\mathrm{y}$ & $\mathrm{y}$ & $\mathrm{y}$ & $\mathrm{y}$ \\
\hline 4970352 & $\mathrm{y}$ & $y^{12}$ & $\mathrm{n}$ & $\mathrm{y}$ & $\mathrm{y}$ & $\mathrm{y}$ \\
\hline 4970357 & $\mathrm{y}$ & $\mathrm{n}$ & $\mathrm{n}$ & $\mathrm{y}$ & $\mathrm{y}$ & $\mathrm{y}$ \\
\hline 4970368 & $\mathrm{y}$ & $\mathrm{n}$ & $\mathrm{y}$ & $\mathrm{y}$ & $\mathrm{y}$ & $\mathrm{y}$ \\
\hline 9364146 & $\mathrm{y}$ & $\mathrm{n}$ & $\mathrm{y}$ & $\mathrm{y}$ & $\mathrm{y}$ & $\mathrm{y}$ \\
\hline
\end{tabular}




\begin{tabular}{|c|c|c|c|c|c|c|}
\hline 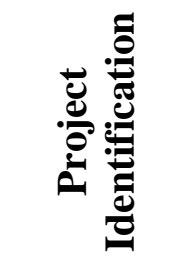 & 总 & 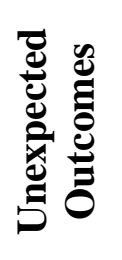 & 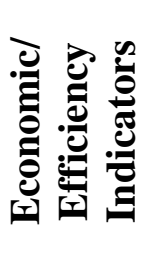 & 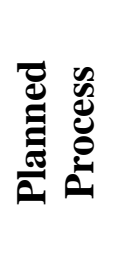 & 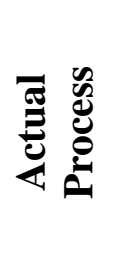 & 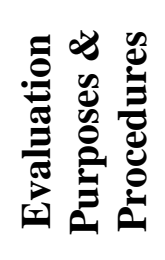 \\
\hline \multicolumn{7}{|l|}{ Philippines } \\
\hline $\begin{array}{c}\text { Total } \\
\text { Numbers }\end{array}$ & $\begin{array}{c}22 y \\
3 n\end{array}$ & $\begin{array}{c}8 y \\
17 \mathrm{n}\end{array}$ & $\begin{array}{l}15 \mathrm{y} \\
10 \mathrm{n}\end{array}$ & $\begin{array}{c}23 y \\
2 n\end{array}$ & $\begin{array}{c}24 y \\
1 \mathrm{n}\end{array}$ & $\begin{array}{c}23 y \\
2 n\end{array}$ \\
\hline
\end{tabular}

*This number references the item number in the Data Collection Instrument in Appendix A.

${ }^{1}$ Evaluation procedures not very specific.

2 Evaluation does not provide enough information to determine whether or not all objectives were included.

3 Increased food production was a goal but was not evaluated.

${ }^{4}$ Only objectives that project managers deemed in trouble of meeting the end of project goals were evaluated.

5 Project managers had not planned on problems that developed because of the requirement for crop pesticide certification.

${ }^{6}$ Unexpected political problems occurred in developing school.

7 The farmer organization generated money through commercial activities which were not part of the original project.

${ }^{8}$ While the project anticipated reaching only the planning stage concerning policy changes, the policy changes were actualized.

${ }^{9}$ Contract farming benefited both small farmers and agribusiness.

10 Project also provided drinking water during the dry season and the production of fish.

${ }^{11}$ Because of farmer participation in the development of the project, the evaluators noted the increased success of the project.

12 The use of the forums process was noted as a model for effective interagency cooperation.

\section{Latin America and the Caribbean.}

Thirty-one projects conducted in Latin America and the Caribbean had at least one evaluation conducted and reported. Evaluators attempted to evaluate all of the indicated project objectives for 23 of these projects. In addition, unexpected outcomes of the project were noted for 6 of these projects (Table 4.8) and all were positive. Economic or efficiency indicators were reported for 23 of the 31 projects. Both the project's planned and actual processes were reported for 24 of the projects. Twenty-seven projects had evaluations which indicated the purpose of the evaluation and the procedures followed by the evaluators. 
Table 4.8

Project Identification $(1 *)$, Project Objectives $\left(15^{*}\right)$, Unexpected Outcomes $\left(16^{*}\right)$, Economic and Efficiency Indicators $(17.1 *)$, Planned Process $\left(17.2^{*}\right)$, Actual Process $\left(17.3^{*}\right)$, and Evaluation Purposes and Procedures $\left(17.4^{*}\right)$ Noted for Latin America and the Caribbean

\begin{tabular}{|c|c|c|c|c|c|c|}
\hline 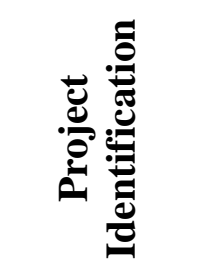 & 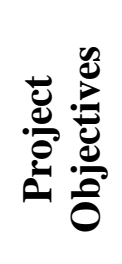 & 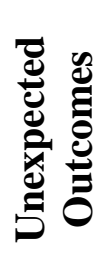 & 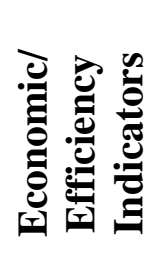 & 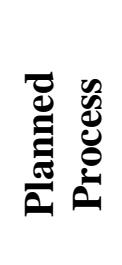 & 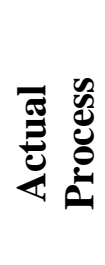 & 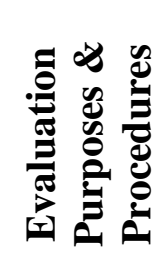 \\
\hline 5050008 & $\mathrm{n}^{1}$ & $\mathrm{n}$ & $\mathrm{n}$ & $\mathrm{n}$ & $\mathrm{n}$ & $\mathrm{y}$ \\
\hline 5050023 & $\mathrm{y}$ & $\mathrm{n}$ & $\mathrm{n}$ & $\mathrm{y}$ & $\mathrm{y}$ & $\mathrm{n}$ \\
\hline 5050036 & $\mathrm{y}$ & $\mathrm{n}$ & $\mathrm{y}$ & $\mathrm{n}$ & $\mathrm{n}$ & $\mathrm{y}$ \\
\hline 5110589 & $n^{2}$ & $\mathrm{n}$ & $\mathrm{y}$ & $\mathrm{y}$ & $\mathrm{y}$ & $\mathrm{y}$ \\
\hline 5150227 & $\mathrm{n}^{3}$ & $\mathrm{n}$ & $\mathrm{n}$ & $\mathrm{n}$ & $\mathrm{n}$ & $\mathrm{y}$ \\
\hline 5150243 & $\mathrm{n}^{4}$ & $\mathrm{n}$ & $\mathrm{n}$ & $\mathrm{n}$ & $\mathrm{n}$ & $\mathrm{y}$ \\
\hline 5170156 & $\mathrm{n}^{5}$ & $\mathrm{n}$ & $\mathrm{n}$ & $\mathrm{y}$ & $\mathrm{y}$ & $\mathrm{n}$ \\
\hline 5170159 & $\mathrm{y}$ & $\mathrm{y}^{9}$ & $\mathrm{y}$ & $\mathrm{y}$ & $\mathrm{y}$ & $\mathrm{y}$ \\
\hline 5170186 & $\mathrm{y}$ & $\mathrm{n}$ & $\mathrm{y}$ & $\mathrm{y}$ & $\mathrm{y}$ & $\mathrm{y}$ \\
\hline 5170214 & $\mathrm{y}$ & $\mathrm{n}$ & $\mathrm{y}$ & $\mathrm{y}$ & $\mathrm{y}$ & $\mathrm{y}$ \\
\hline 5180019 & $n^{6}$ & $\mathrm{n}$ & $\mathrm{n}$ & $\mathrm{n}$ & $\mathrm{n}$ & $\mathrm{y}$ \\
\hline 5180051 & $\mathrm{y}$ & $\mathrm{n}$ & $\mathrm{y}$ & $\mathrm{y}$ & $\mathrm{y}$ & $\mathrm{y}$ \\
\hline 5190307 & $\mathrm{y}$ & $\mathrm{n}$ & $\mathrm{y}$ & $\mathrm{y}$ & $\mathrm{y}$ & $\mathrm{y}$ \\
\hline 5190327 & $\mathrm{y}$ & $\mathrm{n}$ & $\mathrm{y}$ & $\mathrm{y}$ & $\mathrm{y}$ & $\mathrm{y}$ \\
\hline $5200276^{15}$ & $\mathrm{n}^{7}$ & $\mathrm{n}$ & $\mathrm{y}$ & $\mathrm{y}$ & $\mathrm{y}$ & $\mathrm{y}$ \\
\hline 5200330 & $\mathrm{y}$ & $\mathrm{n}$ & $\mathrm{y}$ & $\mathrm{y}$ & $\mathrm{y}$ & $\mathrm{y}$ \\
\hline 5210216 & $\mathrm{y}$ & $\mathrm{n}$ & $\mathrm{y}$ & $\mathrm{y}$ & $\mathrm{y}$ & $y^{16}$ \\
\hline 5220207 & $\mathrm{y}$ & $\mathrm{n}$ & $\mathrm{y}$ & $\mathrm{y}$ & $\mathrm{y}$ & $\mathrm{y}$ \\
\hline 5220246 & $\mathrm{y}$ & $\mathrm{n}$ & $\mathrm{y}$ & $\mathrm{n}$ & $\mathrm{n}$ & $\mathrm{n}$ \\
\hline 5220249 & $n^{8}$ & $y^{10}$ & $\mathrm{y}$ & $\mathrm{y}$ & $\mathrm{y}$ & $\mathrm{y}$ \\
\hline 5220252 & $\mathrm{y}$ & $\mathrm{n}$ & $\mathrm{n}$ & $\mathrm{n}$ & $\mathrm{n}$ & $\mathrm{n}$ \\
\hline 5220268 & $\mathrm{y}$ & $y^{11}$ & $\mathrm{y}$ & $\mathrm{y}$ & $\mathrm{y}$ & $\mathrm{y}$ \\
\hline 5220292 & $\mathrm{y}$ & $\mathrm{n}$ & $\mathrm{y}$ & $\mathrm{y}$ & $\mathrm{y}$ & $\mathrm{y}$ \\
\hline 5270282 & $\mathrm{y}$ & $\mathrm{n}$ & $\mathrm{n}$ & $\mathrm{y}$ & $\mathrm{y}$ & $\mathrm{y}$ \\
\hline 5270293 & $\mathrm{y}$ & $\mathrm{n}$ & $\mathrm{y}$ & $\mathrm{y}$ & $\mathrm{y}$ & $\mathrm{y}$ \\
\hline 5270349 & $\mathrm{y}$ & $\mathrm{n}$ & $\mathrm{y}$ & $\mathrm{y}$ & $\mathrm{y}$ & $\mathrm{y}$ \\
\hline 5320101 & $\mathrm{y}$ & $\mathrm{n}$ & $\mathrm{y}$ & $\mathrm{y}$ & $\mathrm{y}$ & $\mathrm{y}$ \\
\hline $\begin{array}{c}9364146 \\
\text { Costa Rica }\end{array}$ & $\mathrm{y}$ & $\mathrm{n}$ & $\mathrm{y}$ & $\mathrm{y}$ & $\mathrm{y}$ & $\mathrm{y}$ \\
\hline $\begin{array}{c}9365826 \\
\text { Honduras } \\
\end{array}$ & $\mathrm{y}$ & $y^{12}$ & $\mathrm{y}$ & $\mathrm{y}$ & $\mathrm{y}$ & $\mathrm{y}$ \\
\hline $\begin{array}{l}9365826 \\
\text { Ecuador }\end{array}$ & $\mathrm{y}$ & $y^{13}$ & $\mathrm{y}$ & $\mathrm{y}$ & $\mathrm{y}$ & $\mathrm{y}$ \\
\hline
\end{tabular}




\begin{tabular}{|c|c|c|c|c|c|c|}
\hline & 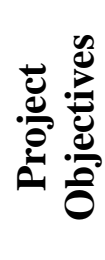 & 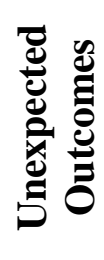 & 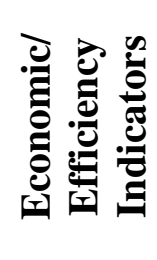 & 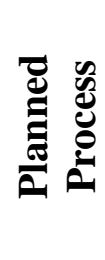 & 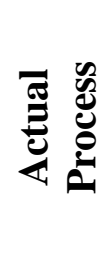 & 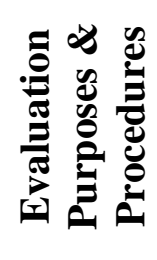 \\
\hline $\begin{array}{c}9365826 \\
\text { Peru }\end{array}$ & $\mathrm{y}$ & $y^{14}$ & $\mathrm{y}$ & $\mathrm{y}$ & $\mathrm{y}$ & $\mathrm{y}$ \\
\hline Total & $23 \mathrm{y}$ & $6 y$ & $23 \mathrm{y}$ & $24 \mathrm{y}$ & $24 \mathrm{y}$ & $27 y$ \\
\hline Numbers & $8 \mathrm{n}$ & $25 \mathrm{n}$ & $8 \mathrm{n}$ & $7 \mathrm{n}$ & $7 \mathrm{n}$ & $4 \mathrm{n}$ \\
\hline
\end{tabular}

*This number references the item number in the Data Collection Instrument in Appendix A.

${ }^{1}$ Could not tell from the information provided.

2 Farmer income was a goal but not evaluated.

${ }^{3}$ Could not tell from the information provided.

${ }_{5}^{4}$ Only goals concerned with environmental sustainability were evaluated.

${ }^{5}$ Increasing income was an objective not evaluated.

${ }^{6}$ Could not tell from the information provided.

${ }^{7}$ Only objectives within the cooperative development portion of the project were evaluated.

${ }^{8}$ Evaluators discussed all of the project's objectives but could not evaluate any of them because baseline data was not available.

${ }^{9}$ Another area began their own irrigation system based on the technology being transferred by the project.

${ }^{10}$ Technology was transferred from the commercial farms to the subsistence farms by the day laborers employed by the commercial farms.

${ }^{11}$ Farmers outside of the project area also constructed irrigation systems.

${ }^{12}$ Because of radio broadcasts about the project, 13 other communities asked for help.

${ }^{13}$ Because of radio broadcasts about the project, 13 other communities asked for help.

${ }^{14}$ Because of radio broadcasts about the project, 13 other communities asked for help.

${ }^{15}$ Evaluators noted the absence of baseline data.

${ }^{16}$ Very little information provided on evaluation methodology.

\section{Study Question 2: What Types of Evaluations Were Completed and Available to the Public?}

Each project was categorized as either a formal evaluation or in informal

evaluation by the criteria discussed in Chapters 2 and 3. Additionally, each project was also categorized as either an interim, final or impact evaluation. 


\section{Evaluation Type Summary}

The most prevalent type of evaluation was formal with 168 evaluations covering 85 projects (Table 4.9). The number of interim evaluations and final evaluations were about the same with interim evaluations accounting for 120 reports for 67 projects and final evaluations accounting for 105 reports for 64 projects. Only one impact evaluation was found. Latin America had 42 projects with evaluations, Africa had 51 projects evaluated, and Asia had 35 projects evaluated.

Table 4.9

Summary of Evaluation Types by World Regions

\begin{tabular}{|c|c|c|c|c|c|c|}
\hline 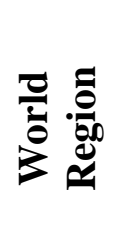 & 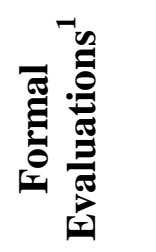 & 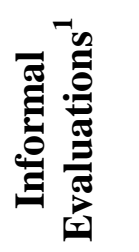 & 吾 & 焉 & 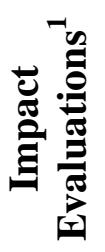 & $\frac{\frac{n}{\pi}}{\frac{\pi}{0}}$ \\
\hline$\overline{\text { Africa }}$ & 49 (30) & $31(21)$ & $38(24)$ & $42(26)$ & $0(0)$ & $80(51)$ \\
\hline Asia & $43(25)$ & $13(10)$ & $33(21)$ & $23(15)$ & $0(0)$ & $56(35)$ \\
\hline LAC & $76(30)$ & $14(12)$ & $49(22)$ & $40(23)$ & $1(1)$ & $90(42)$ \\
\hline Totals & $168(85)$ & $58(43)$ & $120(67)$ & $105(64)$ & $1(1)$ & $226(128)$ \\
\hline
\end{tabular}

Note. The number in the parenthesis represents the number of projects associated with the evaluations.

\section{Informal Evaluations:}

Table 4.10, Table 4.11, and Table 4.12 lists those projects grouped by world region which reported an informal type of evaluation.

\section{Africa.}

Twenty-one projects conducted in Africa had 31 informal evaluations. Fifteen projects had one evaluation each. Project 6320221 had 6 evaluations.

Table 4.10

Projects Conducted in Africa with Informal Type of Evaluations

\begin{tabular}{|c|c|}
\hline \hline Project Identification & Evaluation Identification \\
\hline 6020001 & PD-AAX-760 \\
\hline 6020002 & PD-ABL-224 \\
\hline 6080196 & PD-ABI-331 \\
\hline 6120215 & PD-ABF-593 \\
\hline 6310059 & PD-ABH-851 \\
\hline
\end{tabular}




\begin{tabular}{|c|c|}
\hline Project Identification & Evaluation Identification \\
\hline 6320221 & PD-ABM-179 \\
& PD-ABM-180 \\
& PD-ABM-181 \\
& PD-ABM-182 \\
& PD-ABM-183 \\
& PD-ABM-184 \\
\hline 6320228 & PD-ABL-958 \\
\hline 6350236 & PD-ABK-966 \\
\hline 6560218 & PD-ABF-056 \\
\hline 6600119 & PD-ABI-765 \\
\hline 6640343 & PD-ABH-366 \\
& PD-ABE-038 \\
\hline 6750212 & PD-AAX-906 \\
\hline 6770062 & PD-ABM-118 \\
\hline 6850269 & PD-ABC-945 \\
& PD-ABC-714 \\
\hline 6850957 & PD-ABF-098 \\
\hline 6870101 & PD-AAU-520 \\
\hline 6880934 & PD-AAY-298 \\
\hline 6960110 & PD-ABH-602 \\
& PD-ABE-340 \\
\hline 9365826 (Swaziland) & PD-ABG-460 \\
\hline 9380290 & PD-ABE-783 \\
Senegal & PD-ABA-176 \\
\hline 9380290 & PD-ABE-783 \\
\hline Gambia & PD-ABA-176 \\
\hline
\end{tabular}

Note. Where the same project identification number was used for a project conducted in different countries, the country name was included to aid in identification.

\section{Asia.}

Ten projects conducted in Asia had 13 informal evaluations (Table 4.11). Eight projects had just one evaluation and project 3830080 had three informal evaluations.

Table 4.11

Projects Conducted in Asia with Informal Type of Evaluations

\begin{tabular}{|c|c|}
\hline \hline Project Identification & Evaluation Identification \\
\hline 3670148 & PD-ABD-103 \\
\hline 3670153 & PD-ABL-706 \\
\hline 3830080 & PD-ABJ-377 \\
& PD-ABJ-402 \\
& PD-ABJ-349 \\
\hline
\end{tabular}




\begin{tabular}{|c|c|}
\hline Project Identification & Evaluation Identification \\
\hline 3830083 & PD-ABJ-358 \\
\hline 3860489 & PD-ABI-563 \\
\hline 3860490 & PD-ABI-562 \\
\hline 3910489 & PD-ABJ-830 \\
\hline 3910491 & PD-ABH-942 \\
& PD-ABL-575 \\
\hline 4970304 & PD-ABC-030 \\
\hline 4970342 & PD-ABA-899 \\
\hline
\end{tabular}

\section{Latin America and the Caribbean.}

Twelve projects conducted in Latin America and the Caribbean had 14 informal evaluations (Table 4.12). Ten of the projects had only one evaluation each and two projects (5050002 and 5150227) had two evaluations each.

Table 4.12

Projects Conducted in Latin America and the Caribbean with Informal Type of Evaluations

\begin{tabular}{|c|c|}
\hline \hline Project Identification & Evaluation Identification \\
\hline 5050023 & PD-ABA-935 \\
& PD-AAZ-556 \\
\hline 5150227 & PD-ABK-898 \\
& PN-ABE-578 \\
\hline 5170156 & PD-ABE-130 \\
\hline 5170186 & PD-ABF-534 \\
\hline 5170214 & PD-ABH-935 \\
\hline 5190307 & PD-ABI-155 \\
\hline 5220207 & PD-ABL-864 \\
\hline 5220249 & PD-AAZ-944 \\
\hline 5220252 & PD-ABD-994 \\
\hline 9365826 (Honduras) & PD-ABG-460 \\
\hline 9365826 (Ecuador) & PD-ABG-460 \\
\hline 9365826 (Peru) & PD-ABG-460 \\
\hline
\end{tabular}

Note. Where the same project identification number was used for a project conducted in different countries, the country name was included to aid in identification.

\section{Formal Evaluations}

There were 168 formal evaluations completed for 85 different projects. Tables $4.13,4.14$, and 4.15 identifies those projects and their corresponding evaluations. 


\section{Africa.}

Thirty projects were conducted in Africa (Table 4.13) with 49 formal evaluations.

Project 9365826 had 5 formal evaluations and project 6640343 had four formal evaluations.

Table 4.13

Projects Conducted in Africa with Formal Type of Evaluations

\begin{tabular}{|c|c|}
\hline Project Identification & Evaluation Identification \\
\hline 2980192 & PD-AAU-897 \\
\hline 3980158 & PD-ABI-327 \\
\hline 6080196 & $\begin{array}{l}\text { PD-ABI-345 } \\
\text { PD-ABE-180 }\end{array}$ \\
\hline 6080210 & PD-ABM-449 \\
\hline 6110207 & PD-BCH-593 \\
\hline 6110214 & $\begin{array}{c}\text { PD-ABE-277 } \\
\text { XD-ABM-717A }\end{array}$ \\
\hline 6120215 & $\begin{array}{l}\text { PD-ABB-368 } \\
\text { PD-AAZ-355 }\end{array}$ \\
\hline 6150221 & PD-ABD-227 \\
\hline 6150239 & PD-ABM-075 \\
\hline 6150250 & PD-ABL-597 \\
\hline 6170114 & PD-ABJ-852 \\
\hline 6310059 & PD-ABE-484 \\
\hline 6310083 & $\begin{array}{l}\text { PD-ABI-949 } \\
\text { PD-ABJ-513 } \\
\end{array}$ \\
\hline 6320221 & PD-AAZ-172 \\
\hline 6320228 & $\begin{array}{l}\text { PD-ABL-299 } \\
\text { PD-ABL-801 }\end{array}$ \\
\hline 6560218 & $\begin{array}{l}\text { PD-ABE-009 } \\
\text { PD-ABM-496 }\end{array}$ \\
\hline 6570012 & $\begin{array}{l}\text { PD-ABC-626 } \\
\text { PD-ABD-984 } \\
\text { PD-ABD-208 }\end{array}$ \\
\hline 6600119 & $\begin{array}{l}\text { PD-AAZ-506 } \\
\text { PD-AAZ-389 }\end{array}$ \\
\hline 6600124 & PD-ABI-767 \\
\hline 6640343 & $\begin{array}{l}\text { PD-ABH-363 } \\
\text { PD-ABF-983 } \\
\text { PD-ABC-785 } \\
\text { PD-ABC-990 }\end{array}$ \\
\hline 6750212 & PD-ABD-179 \\
\hline 6760016 & PD-AAZ-169 \\
\hline 6820934 & PD-BBG-585 \\
\hline
\end{tabular}




\begin{tabular}{|c|c|}
\hline Project Identification & Evaluation Identification \\
\hline 6850269 & PD-ABC-439 \\
& PD-ABB-952 \\
\hline 6850280 & PD-ABC-440 \\
\hline 6850283 & PD-ABC-420 \\
\hline 6850288 & PD-ABA-755 \\
\hline 6870101 & PD-AAY-993 \\
\hline 6960110 & PD-AAU-912 \\
\hline 9365826 & PD-ABG-193 \\
(Swaziland) & PD-ABF-051 \\
& PD-ABB-287 \\
& PD-ABB-105 \\
& PD-ABB-104 \\
& PD-ABA-347 \\
& PD-ABA-340 \\
\hline
\end{tabular}

Note. Where the same project identification number was used for a project conducted in different countries, the country name was included to aid in identification.

Asia.

Twenty-five projects were conducted in Asia (Table 4.14) with 43 evaluations. Three projects $(49709302,4970347,4970357)$ had three evaluation each. Twelve projects had just one formal evaluation each.

Table 4.14

Projects Conducted in Asia with Formal Type of Evaluations

\begin{tabular}{|c|c|}
\hline Project Identification & Evaluation Identification \\
\hline 2780274 & PD-ABE-410 \\
\hline 3670148 & PD-AAW-304 \\
& PD-AAW-305 \\
\hline 3670153 & PD-AAZ-713 \\
\hline 3670155 & PD-ABM-231 \\
\hline 3670158 & PD-ABG-818 \\
\hline 3830080 & PD-ABD-652 \\
\hline 3830083 & PD-ABB-362 \\
& PD-ABH-394 \\
\hline 3830086 & PD-ABG-048 \\
& PD-ABT-414 \\
\hline 3830111 & PD-ABL-078 \\
\hline 3860489 & PD-AAY-965 \\
& PD-AAZ-209 \\
\hline 3860490 & PD-ABE-430 \\
\hline 3860495 & PD-ABE-511 \\
\hline
\end{tabular}




\begin{tabular}{|c|c|}
\hline Project Identification & Evaluation Identification \\
\hline & $\begin{array}{l}\text { PD-AAZ-020 } \\
\end{array}$ \\
\hline \multirow[t]{3}{*}{3910489} & $\begin{array}{l}\text { PD-ABG-918 } \\
\end{array}$ \\
\hline & PN-ABS-828 \\
\hline & PD-AAZ-050 \\
\hline \multirow[t]{3}{*}{3910491} & PD-ABE-302 \\
\hline & PD-ABD-308 \\
\hline & XD-AAX-872-A \\
\hline 4930337 & PD-ABA-874 \\
\hline \multirow[t]{3}{*}{4970302} & PD-ABB-508 \\
\hline & PN-AAV-962 \\
\hline & PD-AAQ-225 \\
\hline \multirow[t]{2}{*}{4970304} & PD-ABB-364 \\
\hline & PD-AAV-112 \\
\hline 4970311 & PD-AAZ-537 \\
\hline \multirow{2}{*}{4970330} & PD-CAY-890 \\
\hline & PD-AAW-918 \\
\hline \multirow[t]{2}{*}{4970342} & PD-CAY-920 \\
\hline & PN-ABC-064 \\
\hline \multirow[t]{3}{*}{4970347} & PD-ABL-804 \\
\hline & PD-ABB-363 \\
\hline & PD-ABA-227 \\
\hline 4970352 & PD-ABE-959 \\
\hline \multirow[t]{3}{*}{4970357} & PD-ABK-690 \\
\hline & PD-ABD-303 \\
\hline & PD-ABA-075 \\
\hline 4970368 & PD-ABL-666 \\
\hline 9364146 & PD-AAZ-903 \\
\hline
\end{tabular}

\section{Latin America and the Caribbean.}

Thirty projects conducted in Latin America and the Caribbean had 76 formal evaluations (Table 4.15). Project 5220207 had seven evaluations and four projects had five evaluations each.

Table 4.15: Projects Conducted in Latin America and the Caribbean with Formal Type of Evaluations

\begin{tabular}{|c|c|}
\hline Project Identification & Evaluation Identification \\
\hline 5050008 & PD-ABG-137 \\
& PD-ABG-138 \\
& PD-ABG-140 \\
\hline 5050023 & PD-ABC-078 \\
\hline 5050036 & PD-ABC-730 \\
\hline
\end{tabular}




\begin{tabular}{|c|c|}
\hline Project Identification & Evaluation Identification \\
\hline 5100589 & $\begin{array}{l}\text { PD-ABG-400 } \\
\text { PD-ABB-106 } \\
\text { PD-ABC-340 }\end{array}$ \\
\hline 5150227 & PD-AAW-722 \\
\hline 5150243 & $\begin{array}{l}\text { PN-ABS-502 } \\
\text { PD-ABJ-393 } \\
\text { PN-ABT-453 }\end{array}$ \\
\hline 5170156 & PD-AAY-001 \\
\hline 5170159 & $\begin{array}{l}\text { PD-ABB-086 } \\
\text { PD-ABJ-732 }\end{array}$ \\
\hline 5170186 & PD-ABE-707 \\
\hline 5180019 & $\begin{array}{l}\text { PN-ABJ-970 } \\
\text { PD-AAX-824 } \\
\text { PD-ABC-106 }\end{array}$ \\
\hline 5180051 & $\begin{array}{l}\text { PD-AAZ-387 } \\
\text { PD-AAZ-897 } \\
\text { PD-ABM-577 }\end{array}$ \\
\hline 5190307 & $\begin{array}{l}\text { PD-ABE-656 } \\
\text { PD-AAZ-801 }\end{array}$ \\
\hline 5190327 & $\begin{array}{c}\text { PD-ABJ-282 } \\
\text { PD-ABM-067 }\end{array}$ \\
\hline 5200276 & $\begin{array}{l}\text { PD-ABB-539 } \\
\text { PD-AAZ-290 } \\
\text { PD-AAZ-289 }\end{array}$ \\
\hline 5200330 & $\begin{array}{l}\text { PD-AAZ-185 } \\
\text { PD-ABA-975 }\end{array}$ \\
\hline 5210216 & PD-AAJ-001 \\
\hline 5220207 & $\begin{array}{l}\text { PD-ABM-175 } \\
\text { PD-ABL-073 } \\
\text { PD-WAJ-561 } \\
\text { PD-AAY-537 } \\
\text { PD-AAY-551 } \\
\text { PD-ABC-300 } \\
\text { PD-ABM-465 }\end{array}$ \\
\hline 5220246 & $\begin{array}{l}\text { PD-ABE-753 } \\
\text { PD-ABD-604 }\end{array}$ \\
\hline 5220249 & $\begin{array}{l}\text { PD-ABL-072 } \\
\text { PD-AAZ-680 } \\
\text { PD-AAZ-023 } \\
\text { PD-AAY-929 } \\
\text { PD-ABM-464 }\end{array}$ \\
\hline 5220252 & $\begin{array}{l}\text { PD-ABH-924 } \\
\text { PD-ABE-308 }\end{array}$ \\
\hline
\end{tabular}




\begin{tabular}{|c|c|}
\hline Project Identification & Evaluation Identification \\
\hline & PD-ABA-441 \\
\hline 5220268 & PD-ABJ-523 \\
& PD-ABH-884 \\
& PD-ABA-162 \\
\hline 5220292 & PD-ABH-923 \\
& PD-ABG-874 \\
\hline 5270282 & PD-ABI-940 \\
\hline 5270293 & PD-AAW-940 \\
\hline 5270349 & PD-ABM-456 \\
\hline 5320101 & PD-ABE-131 \\
& PD-ABA-885 \\
\hline 9364146 & PD-ABA-390 \\
\hline Costa Rica) & PD-AAZ-903 \\
\hline 9365826 & PD-ABB-287 \\
(Honduras) & PD-ABB-105 \\
& PD-ABB-104 \\
& PD-ABA-347 \\
& PD-ABA-340 \\
\hline 9365826 & PD-ABB-287 \\
(Ecuador) & PD-ABB-105 \\
& PD-ABB-104 \\
& PD-ABA-347 \\
& PD-ABA-340 \\
\hline 9365826 & PD-ABB-287 \\
(Peru) & PD-ABB-105 \\
9365826 & PD-ABB-104 \\
(Peru) & PD-ABA-347 \\
& PD-ABA-340 \\
\hline
\end{tabular}

Note. Where the same project identification number was used for a project conducted in different countries, the country name was included to aid in identification.

\section{Interim Evaluations}

There were 120 interim evaluations completed for 67 different projects. Tables 4.16, 4.17, and 4.18 identifies those projects and their corresponding evaluations. 


\section{Africa.}

There were 24 projects with 38 interim evaluations in Africa (Table 4.16). Eight projects had more than one evaluation completed. Project 9365826 had 5 evaluations completed and three projects $(6560218,6560218,6870101)$ had three evaluations each.

Table 4.16

Projects Conducted in Africa with Interim Type of Evaluations

\begin{tabular}{|c|c|}
\hline Project Identification & Evaluation Identification \\
\hline 2980192 & PD-AAU-897 \\
\hline 6020001 & PD-AAX-760 \\
\hline 6080210 & PD-ABM-449 \\
\hline 6110207 & PD-BCH-593 \\
\hline 6110214 & PD-ABE-277 \\
\hline 6120215 & $\begin{array}{l}\text { PD-ABB-368 } \\
\text { PD-AAZ-355 }\end{array}$ \\
\hline 6170114 & PD-ABJ-852 \\
\hline 6310059 & PD-ABE-484 \\
\hline 6310083 & $\begin{array}{l}\text { PD-ABI-949 } \\
\text { PD-ABJ-513 }\end{array}$ \\
\hline 6320221 & PD-AAZ-172 \\
\hline 6560218 & $\begin{array}{l}\text { PD-ABF-056 } \\
\text { PD-ABE-009 } \\
\text { PD-ABM-496 }\end{array}$ \\
\hline 6570012 & PD-ABD-984 \\
\hline 6600119 & $\begin{array}{l}\text { PD-AAZ-506 } \\
\text { PD-AAZ-389 }\end{array}$ \\
\hline 6640343 & $\begin{array}{l}\text { PD-ABE-038 } \\
\text { PD-ABC-785 } \\
\text { PD-ABC-990 }\end{array}$ \\
\hline 6750212 & PD-ABD-179 \\
\hline 6760016 & PD-AAZ-169 \\
\hline 6850269 & $\begin{array}{l}\text { PD-ABC-439 } \\
\text { PD-ABB-952 }\end{array}$ \\
\hline 6850280 & PD-ABC-440 \\
\hline 6850283 & PD-ABC-420 \\
\hline 6870101 & $\begin{array}{l}\text { PD-AAY-993 } \\
\text { PD-AAU-912 } \\
\text { PD-AAU-520 }\end{array}$ \\
\hline 6880934 & PD-AAY-298 \\
\hline $\begin{array}{c}9365826 \\
\text { (Swaziland) }\end{array}$ & $\begin{array}{l}\text { PD-ABB-287 } \\
\text { PD-ABB-105 } \\
\text { PD-ABB-104 } \\
\text { PD-ABA-347 }\end{array}$ \\
\hline
\end{tabular}




\begin{tabular}{|c|c|}
\hline Project Identification & Evaluation Identification \\
\hline & PD-ABA-340 \\
\hline 9380290 & PD-ABA-176 \\
(Senegal) & \\
\hline $\begin{array}{c}9380290 \\
\text { (Gambia) }\end{array}$ & PD-ABA-176 \\
\hline
\end{tabular}

Note. Where the same project identification number was used for a project conducted in different countries, the country name was included to aid in identification.

Asia.

Twenty-one projects conducted in Asia had thirty-three interim evaluations completed (Table 4.17). Three projects each had three interim evaluations completed.

Table 4.17

Projects Conducted in Asia with Interim Type of Evaluations

\begin{tabular}{|c|c|}
\hline Project Identification & Evaluation Identification \\
\hline 2780274 & PD-ABE-410 \\
\hline 3670148 & $\begin{array}{l}\text { PD-AAW-304 } \\
\text { PD-AAW-305 }\end{array}$ \\
\hline 3670153 & PD-AAZ-713 \\
\hline 3670158 & PD-ABG-818 \\
\hline 3830080 & PD-ABD-652 \\
\hline 3830083 & PD-ABB-362 \\
\hline 3830086 & $\begin{array}{l}\text { PN-ABG-048 } \\
\text { PN-ABT-414 }\end{array}$ \\
\hline 3830111 & $\begin{array}{l}\text { PD-ABL-078 } \\
\end{array}$ \\
\hline 3860489 & $\begin{array}{l}\text { PD-AAY-965 } \\
\text { PD-AAZ-209 }\end{array}$ \\
\hline 3860495 & PD-AAZ-020 \\
\hline 3910489 & $\begin{array}{l}\text { PD-ABG-918 } \\
\text { PN-ABS-828 } \\
\text { PD-AAZ-050 }\end{array}$ \\
\hline 3910491 & $\begin{array}{c}\text { PD-ABE-302 } \\
\text { XD-AAX-872-A }\end{array}$ \\
\hline 4930337 & PD-ABA-874 \\
\hline 4970302 & $\begin{array}{l}\text { PD-ABB-508 } \\
\text { PN-AAV-962 } \\
\text { PD-AAQ-225 }\end{array}$ \\
\hline 4970304 & PD-AAV-112 \\
\hline 4970311 & PD-AAZ-537 \\
\hline 4970342 & $\begin{array}{l}\text { PD-CAY-920 } \\
\text { PN-ABC-064 }\end{array}$ \\
\hline 4970347 & PD-ABB-363 \\
\hline
\end{tabular}




\begin{tabular}{|c|c|}
\hline Project Identification & Evaluation Identification \\
\hline & PD-ABA-227 \\
\hline 4970357 & PD-ABK-690 \\
& PD-ABD-303 \\
\hline 4970368 & PD-ABA-075 \\
\hline 9364146 & PD-ABL-666 \\
(Philippines) & PD-AAZ-903 \\
\hline
\end{tabular}

Note. Where the same project identification number was used for a project conducted in different countries, the country name was included to aid in identification.

\section{Latin America and the Caribbean.}

Twenty-two projects in Latin America and the Caribbean had 49 interim evaluations (Table 4.18). Three projects (9365826: Honduras, Ecuador, and Peru) had five interim evaluations each. Project 5220207 had four interim evaluations and three projects $(5180019,5220249,5320101)$ had three evaluations each.

Table 4.18

Projects Conducted in Latin America and the Caribbean with Interim Type of Evaluations

\begin{tabular}{|c|c|}
\hline \hline Project Identification & Evaluation Identification \\
\hline 5110589 & PD-ABB-106 \\
& PD-ABC-340 \\
\hline 5150227 & PD-AAW-722 \\
\hline 5150243 & PD-ABJ-393 \\
\hline 5170159 & PD-ABB-086 \\
\hline 5180019 & PN-ABJ-970 \\
& PD-AAX-824 \\
& PD-ABC-106 \\
\hline 5180051 & PD-AAZ-387 \\
\hline 5190307 & PD-AAZ-897 \\
\hline 5190327 & PD-AAZ-801 \\
\hline 5200276 & PD-ABJ-282 \\
& PD-ABM-067 \\
\hline 5210216 & PD-AAZ-290 \\
\hline 5220207 & PD-AAZ-289 \\
\hline & PD-AAJ-001 \\
\hline & PD-ABL-864 \\
\hline & PD-WAJ-561 \\
\hline 5220249 & PD-AAY-537 \\
& PD-AAY-551 \\
\hline & PD-AAZ-680 \\
\hline
\end{tabular}




\begin{tabular}{|c|c|}
\hline Project Identification & Evaluation Identification \\
\hline 5220252 & PD-AAY-929 \\
\hline 5220268 & PD-ABD-994 \\
\hline 5220292 & PD-ABA-441 \\
\hline 5270293 & PD-ABA-162 \\
\hline 5270349 & PD-ABH-923 \\
\hline 5320101 & PD-AAW-944 \\
\hline & PD-ABM-456 \\
\hline 9364146 & PD-ABE-131 \\
\hline (Costa Rica) & PD-ABA-885 \\
\hline 9365826 & PD-ABA-390 \\
(Honduras) & PD-AAZ-903 \\
& PD-ABB-287 \\
& PD-ABB-105 \\
& PD-ABB-104 \\
\hline 9365826 & PD-ABA-347 \\
(Ecuador) & PD-ABA-340 \\
& PD-ABB-287 \\
& PD-ABB-105 \\
& PD-ABB-104 \\
\hline 9365826 & PD-ABA-347 \\
(Peru) & PD-ABA-340 \\
& PD-ABB-287 \\
& PD-ABB-105 \\
& PD-ABB-104 \\
\hline & PD-ABA-347 \\
& PD-ABA-340 \\
\hline
\end{tabular}

Note. Where the same project identification number was used for a project conducted in different countries, the country name was included to aid in identification.

\section{Final Evaluations}

There were 105 final evaluations completed for 64 different projects. Tables 4.19, 4.20, and 4.21 identifies those projects and their corresponding evaluations.

\section{Africa.}

Africa had 26 projects with 42 final evaluations (Table 4.19). Project 6320221 had 6 final evaluation reports and project 6960110 had four. Three projects (6080196, 6320228, 6640343) had three evaluations each.

Table 4.19

Projects Conducted in Africa with Final Type of Evaluations 


\begin{tabular}{|c|c|}
\hline Project Identification & Evaluation Identification \\
\hline 3980158 & PD-ABI-327 \\
\hline 6020002 & PD-ABL-224 \\
\hline 6080196 & $\begin{array}{l}\text { PD-ABI-345 } \\
\text { PD-ABI-331 } \\
\text { PD-ABE-180 }\end{array}$ \\
\hline 6110214 & XD-ABM-717A \\
\hline 6120215 & PD-ABF-593 \\
\hline 6150221 & PD-ABD-227 \\
\hline 6150239 & PD-ABM-075 \\
\hline 6150250 & PD-ABL-597 \\
\hline 6310059 & PD-ABH-851 \\
\hline 6320221 & $\begin{array}{l}\text { PD-ABM-179 } \\
\text { PD-ABM-180 } \\
\text { PD-ABM-181 } \\
\text { PD-ABM-182 } \\
\text { PD-ABM-183 } \\
\text { PD-ABM-184 }\end{array}$ \\
\hline 6320228 & $\begin{array}{l}\text { PD-ABL-299 } \\
\text { PD-ABL-958 } \\
\text { PD-ABL-801 }\end{array}$ \\
\hline 6350236 & PD-ABK-966 \\
\hline 6570012 & $\begin{array}{l}\text { PD-ABC-626 } \\
\text { PD-ABD-208 }\end{array}$ \\
\hline 6600119 & PD-ABI-765 \\
\hline 6600124 & PD-ABI-767 \\
\hline 6640343 & $\begin{array}{l}\text { PD-ABH-363 } \\
\text { PD-ABH-366 } \\
\text { PD-ABF-983 }\end{array}$ \\
\hline 6750212 & PD-AAX-906 \\
\hline 6770062 & PD-ABM-118 \\
\hline 6820934 & PD-BBG-585 \\
\hline 6850269 & $\begin{array}{l}\text { PD-ABC-945 } \\
\text { PD-ABC-714 }\end{array}$ \\
\hline 6850288 & PD-ABA-755 \\
\hline 6850957 & PD-ABF-098 \\
\hline 6960110 & $\begin{array}{l}\text { PD-ABH-602 } \\
\text { PD-ABG-193 } \\
\text { PD-ABE-340 } \\
\text { PD-ABF-051 }\end{array}$ \\
\hline $\begin{array}{c}9365826 \\
\text { (Swaziland) }\end{array}$ & PD-ABG-460 \\
\hline $\begin{array}{l}9380290 \\
\text { (Senegal) }\end{array}$ & PD-ABE-783 \\
\hline
\end{tabular}




\begin{tabular}{|c|c|}
\hline Project Identification & Evaluation Identification \\
\hline $\begin{array}{c}9380290 \\
\text { (Gambia) }\end{array}$ & PD-ABE-783 \\
\hline
\end{tabular}

Note. Where the same project identification number was used for a project conducted in different countries, the country name was included to aid in identification.

Asia.

In Asia 15 projects had 23 final evaluations (Table 4.20). Two projects (3830080, 3910491) had three evaluations each.

Table 4.20

Projects Conducted in Asia with Final Type of Evaluations

\begin{tabular}{|c|c|}
\hline \hline Project Identification & Evaluation Identification \\
\hline 3670148 & PD-ABD-103 \\
\hline 3670153 & PD-ABL-706 \\
\hline 3670155 & PD-ABM-231 \\
\hline 3830080 & PD-ABJ-377 \\
& PD-ABJ-402 \\
& PD-ABJ-349 \\
\hline 3830083 & PD-ABJ-358 \\
& PD-ABH-394 \\
\hline 3860489 & PD-ABI-563 \\
\hline 3860490 & PD-ABE-430 \\
& PD-ABI-562 \\
\hline 3860495 & PD-ABE-511 \\
\hline 3910489 & PD-ABJ-830 \\
\hline 3910491 & PD-ABD-308 \\
& PD-ABH-942 \\
\hline & PD-ABL-575 \\
\hline 4970304 & PD-ABB-364 \\
\hline 4970330 & PD-ABC-030 \\
\hline 4970342 & PD-CAY-890 \\
\hline 4970347 & PD-AAW-918 \\
\hline 4970352 & PD-ABA-899 \\
\hline & PD-ABL-347 \\
\hline & PD-ABE-959 \\
\hline
\end{tabular}

\section{Latin America and the Caribbean.}

Three projects $(5050008,5050023,5220249)$ had three final evaluations each and project 5220207 had four final evaluations (Table 4.21). There were 40 evaluations for 23 projects. 
Table 4.21

Projects Conducted in Latin America and the Caribbean with Final Type of Evaluations

\begin{tabular}{|c|c|}
\hline Project Identification & Evaluation Identification \\
\hline 5050008 & $\begin{array}{l}\text { PD-ABG-137 } \\
\text { PD-ABG-138 } \\
\text { PD-ABG-140 }\end{array}$ \\
\hline 5050023 & $\begin{array}{l}\text { PD-ABA-935 } \\
\text { PD-ABC-078 } \\
\text { PD-AAZ-556 }\end{array}$ \\
\hline 5050036 & PD-ABC-730 \\
\hline 5110589 & PD-ABG-400 \\
\hline 5150227 & $\begin{array}{l}\text { PD-ABK-898 } \\
\text { PN-ABE-578 }\end{array}$ \\
\hline 5150243 & $\begin{array}{l}\text { PN-ABS-502 } \\
\text { PN-ABT-453 }\end{array}$ \\
\hline 5170156 & $\begin{array}{l}\text { PD-ABE-130 } \\
\text { PD-AAY-001 }\end{array}$ \\
\hline 5170159 & PD-ABJ-732 \\
\hline 5170186 & PD-ABF-534 \\
\hline 5170214 & PD-ABH-935 \\
\hline 5180051 & PD-ABM-577 \\
\hline 5190307 & $\begin{array}{l}\text { PD-ABE-656 } \\
\text { PD-ABI-155 }\end{array}$ \\
\hline 5200276 & PD-ABB-539 \\
\hline 5200330 & $\begin{array}{l}\text { PD-AAZ-185 } \\
\text { PD-ABA-975 }\end{array}$ \\
\hline 5220207 & $\begin{array}{l}\text { PD-ABM-175 } \\
\text { PD-ABL-073 } \\
\text { PD-ABC-300 } \\
\text { PD-ABM-465 }\end{array}$ \\
\hline 5220246 & $\begin{array}{l}\text { PD-ABE-753 } \\
\text { PD-ABD-604 }\end{array}$ \\
\hline 5220249 & $\begin{array}{l}\text { PD-ABL-072 } \\
\text { PD-AAZ-944 } \\
\text { PD-ABM-464 }\end{array}$ \\
\hline 5220252 & $\begin{array}{l}\text { PD-ABH-924 } \\
\text { PD-ABE-308 }\end{array}$ \\
\hline 5220268 & $\begin{array}{l}\text { PD-ABJ-523 } \\
\text { PD-ABH-884 }\end{array}$ \\
\hline 5270282 & PD-ABI-940 \\
\hline $\begin{array}{c}9365826 \\
\text { (Honduras) }\end{array}$ & PD-ABG-460 \\
\hline $\begin{array}{c}9365826 \\
\text { (Ecuador) }\end{array}$ & PD-ABG-460 \\
\hline
\end{tabular}




\begin{tabular}{|c|c|}
\hline Project Identification & Evaluation Identification \\
\hline 9365826 & PD-ABG-460 \\
(Peru) & \\
\hline
\end{tabular}

Note. Where the same project identification number was used for a project conducted in different countries, the country name was included to aid in identification.

\section{$\underline{\text { Impact Evaluations }}$}

Only one project (5170186, Dominican Republic) which was conducted in the Latin America and Caribbean world region had an impact evaluation (PD-ABE-707).

\section{Summary of Evaluation Types}

Table 4.22 summarizes the evaluation types and additionally identified the project's by country. A total of 94 projects with a total budget of $\$ 1.99$ billion conducted in 43 different countries were catalogued. There were 168 formal evaluations, 58 informal evaluations, 49 interim evaluations, 105 final evaluations and one impact evaluation. The most frequent technology that was transferred was production techniques (53 projects).

Table 4.22

Summary of types of evaluations completed by project number, country, type of technology involved, budget, and evaluation types

\begin{tabular}{|l|l|l|r|l|}
\hline & \multicolumn{3}{|l|}{} \\
\hline Summary for Africa: & & & \\
\hline 2980192 & Egypt & Production & $1,268,000$ & 1 formal; 1 interim \\
\hline 3980158 & Egypt & Production & $1,000,000$ & 1 formal; 1 final \\
\hline 6020001 & Comoros & Production & $3,500,000$ & 1 informal; 1 interim \\
\hline 6020002 & Comoros & Production & $3,500,000$ & 1 informal; 1 final \\
\hline 6080196 & Morocco & Production & $6,831,000$ & 2 formal; 1 informal; 3 final \\
\hline 6080210 & Morocco & Marketing & $30,000,000$ & 1 formal; 1 interim \\
\hline 6110207 & Zambia & Policy & $19,876,000$ & 1 formal; 1 interim \\
\hline 6110214 & Zambia & Marketing & $12,100,000$ & 2 formal; 1 interim; 1 final \\
\hline 6120215 & Malawi & Education & $27,500,000$ & 2 formal; 1 informal; 2 interim; \\
\hline 6150221 & Kenya & Production & $4,026,000$ & 1 formal; 1 final \\
\hline 6150239 & Kenya & Education & $10,909,000$ & 1 formal; 1 final \\
\hline
\end{tabular}




\begin{tabular}{|c|c|c|c|c|}
\hline & 泀 & 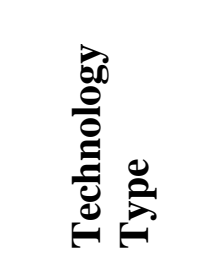 & 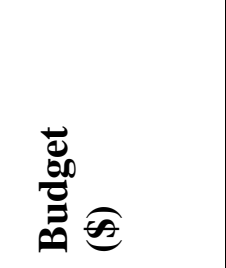 & 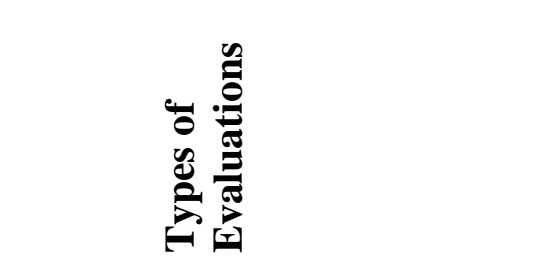 \\
\hline 6150250 & Kenya & Marketing & $2,000,000$ & 1 formal; 1 final \\
\hline 6170114 & Uganda & Marketing & $59,500,000$ & 1 formal; 1 final \\
\hline 6310059 & Cameroon & Policy & $12,000,000$ & $\begin{array}{l}1 \text { formal; } 1 \text { informal; } 1 \text { interim; } \\
1 \text { final }\end{array}$ \\
\hline 6310083 & Cameroon & Marketing & $5,500,000$ & 2 formal; 2 interim \\
\hline 6320221 & Lesotho & Production & $27,454,000$ & $\begin{array}{l}1 \text { formal; } 6 \text { informal; } 1 \text { interim; } \\
6 \text { final }\end{array}$ \\
\hline 6320228 & Lesotho & Production & $6,178,000$ & 2 formal; 1 informal;3 final \\
\hline 6350236 & Gambia & Production & $4,595,000$ & 1 informal; 1 final \\
\hline 6560218 & Mozambique & Policy & $13,500,000$ & 2 formal; 1 informal; 3 interim \\
\hline 6570012 & Guinea Bissau & Production & $2,250,000$ & 3 formal; 1 interim; 2 final \\
\hline 6600119 & Zaire & Policy & $19,000,000$ & $\begin{array}{l}2 \text { formal; } 1 \text { informal; } 2 \text { interim; } \\
1 \text { final }\end{array}$ \\
\hline 6600124 & Zaire & Production & $25,000,000$ & 1 formal; 1 final \\
\hline 6640343 & Tunisia & Policy & $5,501,000$ & $\begin{array}{l}4 \text { formal; } 2 \text { informal; } 3 \text { interim; } \\
3 \text { final }\end{array}$ \\
\hline 6750212 & Guinea & Business & $1,800,000$ & $\begin{array}{l}1 \text { formal; } 1 \text { informal; } 1 \text { interim; } \\
1 \text { final }\end{array}$ \\
\hline 6760016 & $\begin{array}{l}\text { Central Africa } \\
\text { Republic }\end{array}$ & $\begin{array}{l}\text { Post } \\
\text { Production }\end{array}$ & $4,306,000$ & 1 formal; 1 interim \\
\hline 6770062 & Chad & Marketing & $10,000,000$ & 1 informal; 1 final \\
\hline 6820934 & Mauritania & Production & 500,000 & 1 formal; 1 final \\
\hline 6850269 & Senegal & Production & $20,000,000$ & $\begin{array}{l}2 \text { formal; } 2 \text { informal; } \\
2 \text { interim; } 2 \text { final }\end{array}$ \\
\hline 6850280 & Senegal & Production & $9,500,000$ & 1 formal; 1 interim \\
\hline 6850283 & Senegal & Production & $14,000,000$ & 1 formal; 1 interim \\
\hline 6850288 & Senegal & Policy & $12,484,000$ & 1 formal; 1 final \\
\hline 6850957 & Senegal & Production & $5,096,000$ & 1 informal; 1 final \\
\hline 6870101 & Madagascar & Policy & $14,844,000$ & 2 formal; 1 informal; 3 interim \\
\hline 6880934 & Mali & Production & 500,000 & 1 informal; 1 interim \\
\hline 6960110 & Rwanda & Education & $15,700,000$ & 2 formal; 2 informal; 4 final \\
\hline 9365826 & Swaziland & Production & $1,823,750$ & $\begin{array}{l}5 \text { formal; } 1 \text { informal;5 interim; } \\
1 \text { final }\end{array}$ \\
\hline 9380290 & Senegal & Production & 475,000 & 2 informal; 1 interim; 1 final \\
\hline 9380290 & Gambia & Production & 475,000 & 2 informal; 1 interim; 1 final \\
\hline
\end{tabular}




\begin{tabular}{|c|c|c|c|c|}
\hline & 总 & 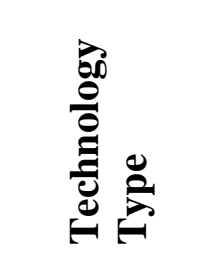 & 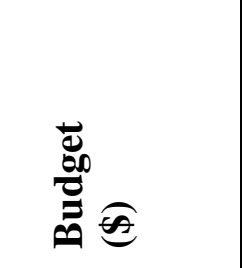 & 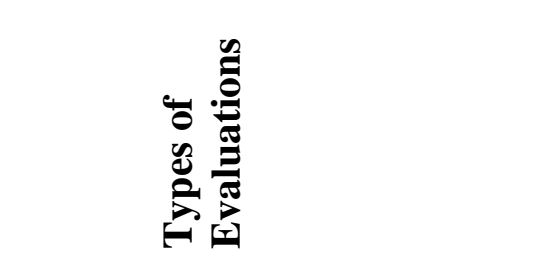 \\
\hline \multicolumn{5}{|c|}{ Subtotal for Africa: } \\
\hline $\begin{array}{c}38 \\
\text { projects }\end{array}$ & 24 countries & $\begin{array}{l}1 \text { business } \\
3 \text { education } \\
6 \text { marketing } \\
7 \text { policy } \\
1 \text { post prod } \\
20 \text { production }\end{array}$ & $414,491,750$ & $\begin{array}{l}49 \text { formal; } 31 \text { informal; } \\
38 \text { interim; } 42 \text { final }\end{array}$ \\
\hline \multicolumn{5}{|c|}{ Summary for Asia: } \\
\hline 2780274 & Jordan & Marketing & $8,300,000$ & 1 formal; 1 interim \\
\hline 3670148 & Nepal & Education & $4,100,000$ & $\begin{array}{l}2 \text { formal; } 1 \text { informal; } 2 \text { interim; } \\
1 \text { final }\end{array}$ \\
\hline 3670153 & Nepal & Production & $18,000,000$ & $\begin{array}{l}1 \text { formal; } 1 \text { informal; } 1 \text { interim; } \\
1 \text { final }\end{array}$ \\
\hline 3670155 & Nepal & Production & $37,600,000$ & 1 formal; 1 final \\
\hline 3670158 & Nepal & Production & $16,000,000$ & 1 formal; 1 interim \\
\hline 3830080 & Sri Lanka & Production & $25,500,000$ & $\begin{array}{l}1 \text { formal; } 3 \text { informal; } 1 \text { interim; } \\
3 \text { final }\end{array}$ \\
\hline 3830083 & Sri Lanka & Policy & $13,200,000$ & $\begin{array}{l}2 \text { formal; } 1 \text { informal; } 1 \text { interim; } \\
2 \text { final }\end{array}$ \\
\hline 3830086 & Sri Lanka & Business & $37,000,000$ & 2 formal; 2 interim \\
\hline 3830111 & Sri Lanka & Business & $20,650,000$ & 1 formal; 1 interim \\
\hline 3860489 & India & Production & $23,581,000$ & $\begin{array}{l}2 \text { formal; } 1 \text { informal; } 2 \text { interim; } \\
1 \text { final }\end{array}$ \\
\hline 3860490 & India & Production & $38,603,000$ & 1 formal; 1 informal; 2 final \\
\hline 3860495 & India & Production & $113,770,000$ & 2 formal; 1 interim; 1 final \\
\hline 3910489 & Pakistan & Production & $64,500,000$ & $\begin{array}{l}3 \text { formal; } 1 \text { informal; } 3 \text { interim; } \\
1 \text { final }\end{array}$ \\
\hline 3910491 & Pakistan & Policy & $35,000,000$ & $\begin{array}{l}3 \text { formal; } 2 \text { informal; } 2 \text { interim; } \\
3 \text { final }\end{array}$ \\
\hline 4930337 & Thailand & Production & $22,000,000$ & 1 formal; 1 interim \\
\hline 4970302 & Indonesia & Production & $28,330,000$ & 3 formal; 3 interim \\
\hline 4970304 & Indonesia & Production & $7,400,000$ & $\begin{array}{l}2 \text { formal; } 1 \text { informal; } 1 \text { interim; } \\
2 \text { final }\end{array}$ \\
\hline 4970311 & Indonesia & Production & $34,706,000$ & 1 formal; 1 interim \\
\hline 4970330 & Indonesia & Production & $5,000,000$ & 2 formal; 2 final \\
\hline 4970342 & Indonesia & Policy & $9,000,000$ & $\begin{array}{l}2 \text { formal; } 1 \text { informal; } 2 \text { interim; } \\
1 \text { interim }\end{array}$ \\
\hline 4970347 & Indonesia & Production & $81,249,000$ & 3 formal; 2 interim; 1 final \\
\hline
\end{tabular}




\begin{tabular}{|c|c|c|c|c|}
\hline & 泀 & 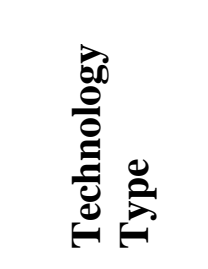 & 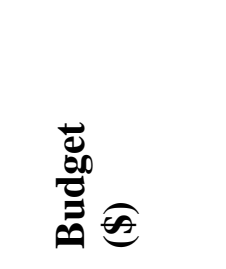 & 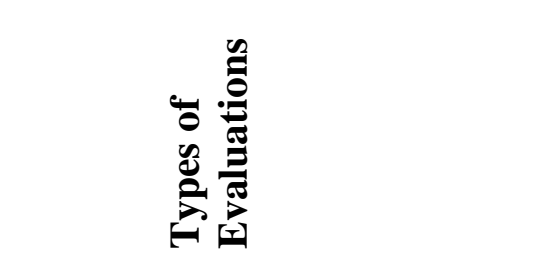 \\
\hline 4970352 & Indonesia & Production & $2,810,000$ & 1 formal; 1 final \\
\hline 4970357 & Indonesia & Policy & $200,000,000$ & 3 formal;3 interim \\
\hline 4970368 & Indonesia & Business & $40,000,000$ & 1 formal; 1 interim \\
\hline 9364146 & Philippines & Production & $2,807,000$ & 1 formal; 1 interim \\
\hline \multicolumn{5}{|c|}{ Subtotal for Asia: } \\
\hline $\begin{array}{c}25 \\
\text { projects }\end{array}$ & 8 countries & $\begin{array}{l}3 \text { business } \\
1 \text { education } \\
1 \text { marketing } \\
4 \text { policy } \\
16 \text { production }\end{array}$ & $889,106,000$ & $\begin{array}{l}43 \text { final; } 13 \text { informal; } \\
33 \text { interim; } 23 \text { final }\end{array}$ \\
\hline \multicolumn{5}{|c|}{ Summary for LAC: } \\
\hline 5050008 & Belize & Production & $16,200,000$ & 3 formal; 3 final \\
\hline 5050023 & Belize & Production & 615,000 & 1 formal; 2 informal; 3 final \\
\hline 5050036 & Belize & Production & 600,000 & 1 formal; 1 final \\
\hline 5110589 & Bolivia & Business & $12,940,000$ & 3 formal; 2 interim; 1 final \\
\hline 5150227 & Costa Rica & Production & 800,000 & $\begin{array}{l}1 \text { formal; } 2 \text { informal; } 1 \text { interim; } \\
2 \text { final }\end{array}$ \\
\hline 5150243 & Costa Rica & Production & $15,000,000$ & 3 formal; 1 interim; 2 final \\
\hline 5170156 & $\begin{array}{l}\text { Dominican } \\
\text { Republic }\end{array}$ & Policy & $1,250,000$ & 1 formal; 1 informal; 2 final \\
\hline 5170159 & $\begin{array}{l}\text { Dominican } \\
\text { Republic }\end{array}$ & Production & $12,849,000$ & 2 formal; 1 interim; 1 final \\
\hline 5170186 & $\begin{array}{l}\text { Dominican } \\
\text { Republic }\end{array}$ & Business & $28,300,000$ & $\begin{array}{l}1 \text { formal; } 1 \text { informal; } 1 \text { final; } 1 \\
\text { impact }\end{array}$ \\
\hline 5170214 & $\begin{array}{l}\text { Dominican } \\
\text { Republic }\end{array}$ & Production & $21,920,000$ & 1 informal; 1 final \\
\hline 5180019 & Ecuador & Marketing & $22,375,000$ & 3 formal; 3 interim \\
\hline 5180051 & Ecuador & Policy & $23,795,000$ & 3 formal; 2 interim; 1 final \\
\hline 5190307 & El Salvador & Policy & $100,000,000$ & 2 formal; 1 informal \\
\hline 5190327 & El Salvador & Business & $58,534,000$ & 2 formal; 2 interim \\
\hline 5200276 & Guatemala & Production & $13,500,000$ & 3 formal; 2 interim; 1 final \\
\hline 5200330 & Guatemala & Policy & $1,000,000$ & 2 formal; 2 final \\
\hline 5210216 & Haiti & Production & $12,440,000$ & 1 formal; 1 interim \\
\hline 5220207 & Honduras & Marketing & $54,914,000$ & $\begin{array}{l}7 \text { formal; } 1 \text { informal; } 4 \text { interim; } \\
4 \text { final }\end{array}$ \\
\hline 5220246 & Honduras & Production & $40,000,000$ & 2 formal; 2 final \\
\hline 5220249 & Honduras & Education & $37,350,000$ & $\begin{array}{l}5 \text { formal; } 1 \text { informal; } 3 \text { interim; } \\
3 \text { final }\end{array}$ \\
\hline 5220252 & Honduras & Business & $28,500,000$ & 3 formal; 1 informal; 2 interim; \\
\hline
\end{tabular}




\begin{tabular}{|c|c|c|c|c|}
\hline 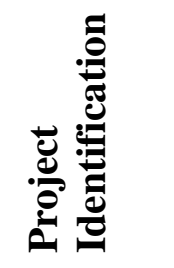 & Ë & 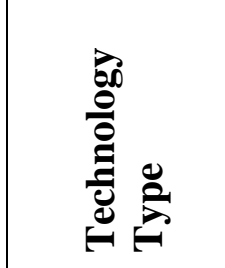 & 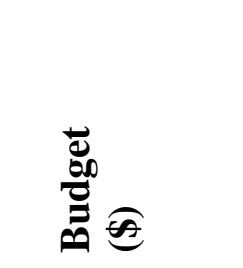 & 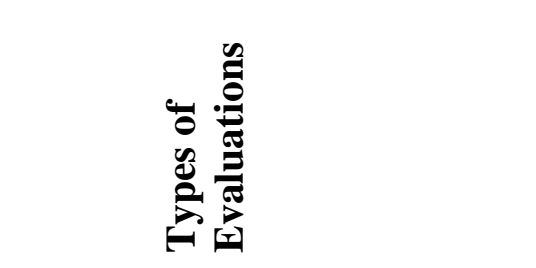 \\
\hline & & & & 2 final \\
\hline 5220268 & Honduras & Production & $33,790,000$ & 3 formal; 1 interim; 2 final \\
\hline 5220292 & Honduras & Production & $54,000,000$ & 2 formal; 2 interim \\
\hline 5270282 & Peru & Education & $45,083,000$ & 1 formal; 1 final \\
\hline 5270293 & Peru & Business & 750,000 & 1 formal; 1 interim \\
\hline 5270349 & Peru & Marketing & $25,500,000$ & 1 formal; 1 interim \\
\hline 5320101 & Jamaica & Production & $20,000,000$ & 3 formal; 3 interim \\
\hline 9364146 & Costa Rica & Production & $2,807,000$ & 1 formal; 1 interim \\
\hline 9365826 & Honduras & Production & $1,823,750$ & $\begin{array}{l}5 \text { formal; } 1 \text { informal; } 5 \text { interim; } \\
1 \text { final }\end{array}$ \\
\hline 9365826 & Ecuador & Production & $1,823,750$ & $\begin{array}{l}5 \text { formal; } 1 \text { informal; } 5 \text { interim; } \\
1 \text { final }\end{array}$ \\
\hline 9365826 & Peru & Production & $1,823,750$ & $\begin{array}{l}5 \text { formal; } 1 \text { informal; } 5 \text { interim; } \\
1 \text { final }\end{array}$ \\
\hline \multicolumn{5}{|c|}{ Subtotals for LAC: } \\
\hline $\begin{array}{c}31 \\
\text { projects }\end{array}$ & 11 countries & $\begin{array}{l}5 \text { business } \\
2 \text { education } \\
3 \text { marketing } \\
4 \text { policy } \\
17 \text { production }\end{array}$ & $690,283,250$ & $\begin{array}{l}76 \text { formal; } 14 \text { informal; } \\
49 \text { interim; } 40 \text { final; } 1 \text { impact }\end{array}$ \\
\hline \multicolumn{5}{|l|}{ Totals: } \\
\hline $\begin{array}{c}94 \\
\text { projects }\end{array}$ & 43 countries & $\begin{array}{l}9 \text { business } \\
6 \text { education } \\
10 \text { marketing } \\
15 \text { policy } \\
1 \text { post prod } \\
53 \text { production }\end{array}$ & $1,993,881,000$ & $\begin{array}{l}168 \text { formal; } 58 \text { informal; } \\
120 \text { interim; } 105 \text { final; } \\
1 \text { impact }\end{array}$ \\
\hline
\end{tabular}

\section{Study Question 3: In What Ways Were the Evaluations Appropriate for Determining Socioeconomic Impacts?}

The reports were analyzed for stakeholder involvement both as an inclusion in the project goals during the project design process and during or afterwards as part of the project evaluation. Also the socioeconomic indicators of income, nutrition, targeted audience reached, groups that benefited and groups that did not benefit, gender equity, environmental, and project sustainability after project funding ceases were recorded. Additionally, several other types of socioeconomic indicators were catalogued and included employment, employability, and reduction of rat bites. 


\section{Stakeholder Involvement}

Ninety-four projects were analyzed for stakeholder involvement. Stakeholders were identified and included in the goals and/or objectives of 35 different projects. Fiftythree of the projects provided no indication about whether or not all stakeholders were included in the project goals and 6 projects provided no information about the stakeholders. Three projects (4970311, 9364146 - Philippines, 9364146 - Costa Rica) did not include farmers as identified stakeholders. Two projects $(3860490,4970311)$ did not include women and in project 2780274 no stakeholders were identified. In project 3910489 the private sector was initially left out, but the omission was recognized and in 1990 the group was added to the project goals.

In the evaluation of forty-four projects input from all of the stakeholders was sought and included during the evaluation process (Table 4.23). Forty projects did not indicate whether or not input was sought from all of the stakeholders and 10 projects did not include input from all of the affected stakeholders. The average project budget in Africa was larger when stakeholders were involved in the evaluation, but for the other two regions the average project budget was larger when stakeholders were not included in the evaluation.

Table 4.23

Average Budgeted Dollar Value per Project for Stakeholder Involvement in Evaluation Process by World Region

\begin{tabular}{|c|c|c|c|c|}
\hline $\begin{array}{c}\text { World } \\
\text { Region }\end{array}$ & \multicolumn{2}{|c|}{ Involved } & \multicolumn{2}{c|}{$\begin{array}{c}\text { Not } \\
\text { Involved }\end{array}$} \\
\hline Africa & Projects & \$ (million) & Projects & \$ (million) \\
\hline Asia & 18 & 11.38 & 20 & 10.48 \\
\hline LAC & 16 & 33.47 & 9 & 39.28 \\
\hline Totals & 44 & 18.97 & 21 & 23.84 \\
\hline
\end{tabular}

${ }^{1}$ Includes projects where the evaluation did not indicate whether or not all stakeholders were involved in the evaluation or groups were identified that were left out of the evaluation. 
In 8 projects identifiable stakeholders were not included in the evaluation. Table 2.24 lists those stakeholders and their associated projects.

Table 4.24

Stakeholders Not Included in Evaluation Input

\begin{tabular}{|c|c|}
\hline \hline Project Identification & Stakeholders \\
\hline 2780274 & $\begin{array}{c}\text { producers } \\
\text { non-participants }\end{array}$ \\
\hline 3670158 & Users of forest \\
\hline 3860490 & women \\
\hline 5050023 & $\begin{array}{c}\text { farmers not selected } \\
\text { farmers burned out }\end{array}$ \\
\hline 5150227 & growers of palm trees \\
\hline 5170214 & all stakeholders \\
\hline 6080210 & non-participants \\
\hline 6880934 & farmers \\
\hline 9364146 & farmers \\
Philippines & farmers \\
\hline 9364146 & \\
\hline Costa Rica & \\
\hline
\end{tabular}

Note. Where the same project identification number was used for a project conducted in different countries, the country name was included to aid in identification.

\section{Socioeconomic Impacts}

Seventy-two of the projects had been evaluated for at least one socioeconomic factor. The two most often reported factors were project sustainability (49 projects) and gender (47 projects). The least evaluated factor was nutrition (3 projects).

\section{Socioeconomic impacts in Africa.}

The two most evaluated socioeconomic factors in the 28 projects conducted in Africa (Table 4.25) were gender and project sustainability. Gender analysis occurred in 19 projects and 22 projects reported on project sustainability. The least reported socioeconomic factor was nutrition (2 projects). 
Table 4.25

Socioeconomic Impacts Evaluated for African Projects

\begin{tabular}{|c|c|c|c|c|c|c|c|c|c|}
\hline 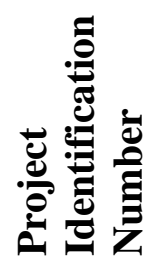 & 导 & 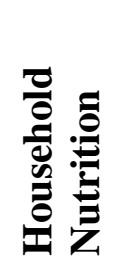 & 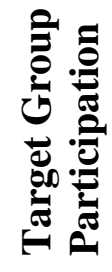 & 串递 & 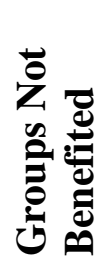 & 离 & 昰 & 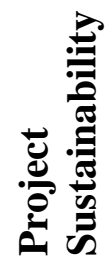 & 递 \\
\hline 2980192 & $\mathrm{n}$ & $\mathrm{n}$ & $\mathrm{n}$ & $\mathrm{n}$ & $\mathrm{n}$ & $\mathrm{y}$ & $\mathrm{n}$ & $\mathrm{n}$ & $\mathrm{n}$ \\
\hline 6020001 & $\mathrm{n}$ & $\mathrm{n}$ & $\mathrm{n}$ & $\mathrm{y}$ & $\mathrm{n}$ & $\mathrm{y}$ & $\mathrm{n}$ & $\mathrm{n}$ & $\mathrm{n}$ \\
\hline 6020002 & $\mathrm{n}$ & $\mathrm{n}$ & $\mathrm{y}$ & $\mathrm{n}$ & $\mathrm{n}$ & $\mathrm{y}$ & $\mathrm{y}$ & $\mathrm{y}$ & $\mathrm{n}$ \\
\hline 6080196 & $\mathrm{n}$ & $\mathrm{n}$ & $\mathrm{n}$ & $\mathrm{n}$ & $\mathrm{n}$ & $\mathrm{n}$ & $\mathrm{y}$ & $\mathrm{y}$ & $\mathrm{n}$ \\
\hline 6080210 & $\mathrm{y}$ & $\mathrm{n}$ & $\mathrm{n}$ & $\mathrm{y}$ & $\mathrm{n}$ & $\mathrm{y}$ & $\mathrm{y}$ & $\mathrm{y}$ & $y^{1}$ \\
\hline 6110214 & $\mathrm{n}$ & $\mathrm{y}$ & $\mathrm{n}$ & $\mathrm{n}$ & $\mathrm{n}$ & $\mathrm{n}$ & $\mathrm{n}$ & $\mathrm{y}$ & $y^{1}$ \\
\hline 6120215 & $\mathrm{n}$ & $\mathrm{n}$ & $\mathrm{n}$ & $\mathrm{n}$ & $\mathrm{n}$ & $\mathrm{y}$ & $\mathrm{y}$ & $\mathrm{n}$ & $\mathrm{n}$ \\
\hline 6150221 & $\mathrm{n}$ & $\mathrm{n}$ & $\mathrm{n}$ & $\mathrm{n}$ & $\mathrm{n}$ & $\mathrm{n}$ & $\mathrm{n}$ & $\mathrm{y}$ & $\mathrm{n}$ \\
\hline 6150239 & $\mathrm{n}$ & $\mathrm{n}$ & $\mathrm{n}$ & $\mathrm{n}$ & $\mathrm{n}$ & $\mathrm{n}$ & $\mathrm{n}$ & $\mathrm{y}$ & $y^{2}$ \\
\hline 6150250 & $\mathrm{y}$ & $\mathrm{n}$ & $\mathrm{n}$ & $\mathrm{n}$ & $\mathrm{n}$ & $\mathrm{y}$ & $\mathrm{n}$ & $\mathrm{y}$ & $\mathrm{n}$ \\
\hline 6170114 & $\mathrm{y}$ & $\mathrm{n}$ & $\mathrm{n}$ & $\mathrm{y}$ & $\mathrm{y}$ & $\mathrm{y}$ & $\mathrm{n}$ & $\mathrm{y}$ & $\mathrm{n}$ \\
\hline 6310083 & $\mathrm{y}$ & $\mathrm{n}$ & $\mathrm{n}$ & $\mathrm{y}$ & $\mathrm{n}$ & $\mathrm{n}$ & $\mathrm{n}$ & $\mathrm{n}$ & $\mathrm{n}$ \\
\hline 6320221 & $\mathrm{n}$ & $\mathrm{n}$ & $\mathrm{n}$ & $\mathrm{n}$ & $\mathrm{n}$ & $\mathrm{n}$ & $\mathrm{n}$ & $\mathrm{y}$ & $\mathrm{n}$ \\
\hline 6320228 & $\mathrm{n}$ & $\mathrm{n}$ & $\mathrm{n}$ & $\mathrm{n}$ & $\mathrm{n}$ & $\mathrm{y}$ & $\mathrm{y}$ & $\mathrm{y}$ & $\mathrm{n}$ \\
\hline 6560218 & $\mathrm{y}$ & $\mathrm{n}$ & $\mathrm{y}$ & $\mathrm{n}$ & $\mathrm{n}$ & $\mathrm{y}$ & $\mathrm{n}$ & $\mathrm{n}$ & $\mathrm{n}$ \\
\hline 6570012 & $\mathrm{n}$ & $\mathrm{n}$ & $\mathrm{n}$ & $\mathrm{n}$ & $\mathrm{n}$ & $\mathrm{y}$ & $\bar{y}$ & $\bar{y}$ & $\mathrm{n}$ \\
\hline 6600119 & $\mathrm{n}$ & $\mathrm{n}$ & $\mathrm{n}$ & $\mathrm{n}$ & $\mathrm{n}$ & $\mathrm{n}$ & $\mathrm{n}$ & $\mathrm{y}$ & $\mathrm{n}$ \\
\hline 6760016 & $\mathrm{y}$ & $\mathrm{y}$ & $\mathrm{y}$ & $\mathrm{y}$ & $\mathrm{y}$ & $\mathrm{y}$ & $\mathrm{y}$ & $\mathrm{y}$ & $y^{3}$ \\
\hline 6770062 & $\mathrm{n}$ & $\mathrm{n}$ & $\mathrm{y}$ & $\mathrm{y}$ & $\mathrm{y}$ & $\mathrm{y}$ & $\mathrm{n}$ & $\mathrm{y}$ & $\mathrm{n}$ \\
\hline 6820934 & $\mathrm{n}$ & $\mathrm{n}$ & $\mathrm{y}$ & $\mathrm{y}$ & $\mathrm{y}$ & $\mathrm{y}$ & $\mathrm{n}$ & $\mathrm{y}$ & $\mathrm{n}$ \\
\hline 6850280 & $\mathrm{y}$ & $\mathrm{n}$ & $\mathrm{n}$ & $\mathrm{y}$ & $\mathrm{y}$ & $\mathrm{y}$ & $\mathrm{n}$ & $\mathrm{y}$ & $y^{1}$ \\
\hline 6850283 & $\mathrm{n}$ & $\mathrm{n}$ & $\mathrm{n}$ & $\mathrm{n}$ & $\mathrm{n}$ & $\mathrm{n}$ & $\mathrm{y}$ & $\mathrm{y}$ & $\mathrm{n}$ \\
\hline 6870101 & $\bar{y}$ & $\mathrm{n}$ & $\mathrm{y}$ & $\mathrm{y}$ & $\mathrm{y}$ & $\mathrm{y}$ & $\mathrm{n}$ & $\mathrm{n}$ & $\mathrm{n}$ \\
\hline 6880934 & $\mathrm{n}$ & $\mathrm{n}$ & $\mathrm{n}$ & $\mathrm{n}$ & $\mathrm{n}$ & $\mathrm{n}$ & $\mathrm{n}$ & $\mathrm{y}$ & $\mathrm{n}$ \\
\hline 6960110 & $\mathrm{n}$ & $\mathrm{n}$ & $\mathrm{n}$ & $\mathrm{n}$ & $\mathrm{n}$ & $\mathrm{y}$ & $\mathrm{n}$ & $\mathrm{y}$ & $\mathrm{n}$ \\
\hline 9365826 & $\mathrm{n}$ & $\mathrm{n}$ & $\mathrm{y}$ & $\mathrm{y}$ & $\mathrm{n}$ & $\mathrm{y}$ & $\mathrm{n}$ & $\mathrm{y}$ & $\mathrm{n}$ \\
\hline 9380290 & $\mathrm{n}$ & $\mathrm{n}$ & $\mathrm{n}$ & $\mathrm{y}$ & $\mathrm{y}$ & $\mathrm{y}$ & $\mathrm{n}$ & $\mathrm{y}$ & $\mathrm{n}$ \\
\hline 9380290 & $\mathrm{n}$ & $\mathrm{n}$ & $\mathrm{n}$ & $\mathrm{y}$ & $\mathrm{y}$ & $\mathrm{y}$ & $\mathrm{n}$ & $\mathrm{y}$ & $\mathrm{n}$ \\
\hline $\begin{array}{c}\text { Total } \\
\text { Numbers }\end{array}$ & $\begin{array}{c}8 \mathrm{y} \\
20 \mathrm{n}\end{array}$ & $\begin{array}{c}2 y \\
26 n\end{array}$ & $\begin{array}{c}7 \mathrm{y} \\
21 \mathrm{n}\end{array}$ & $\begin{array}{l}12 \mathrm{y} \\
16 \mathrm{n}\end{array}$ & $\begin{array}{c}8 \mathrm{y} \\
20 \mathrm{n}\end{array}$ & $\begin{array}{l}19 \mathrm{y} \\
9 \mathrm{n}\end{array}$ & $\begin{array}{c}8 \mathrm{y} \\
20 \mathrm{n}\end{array}$ & $\begin{array}{l}22 y \\
6 n\end{array}$ & $\begin{array}{c}5 \mathrm{y} \\
23 \mathrm{n}\end{array}$ \\
\hline
\end{tabular}

${ }^{1}$ Employment

${ }^{2}$ Employability

${ }^{3}$ Controlling or reducing rat bites in the home 


\section{Socioeconomic impacts in Asia.}

Only one project conducted in Asia evaluated nutritional changes. Three socioeconomic factors were evaluated in at least one-half of the twenty-two projects (Table 4.26). Evaluating whether or not the project reached the targeted group(s) was reported in 14 of the projects. Twelve projects were analyzed for gender participation and 12 for project sustainability.

Table 4.26

Socioeconomic Impacts Evaluated for Asian Projects

\begin{tabular}{|c|c|c|c|c|c|c|c|c|c|}
\hline 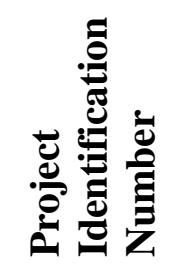 & 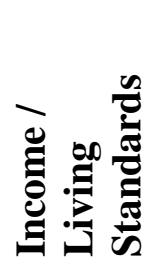 & 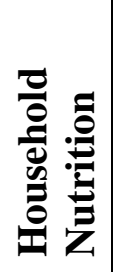 & 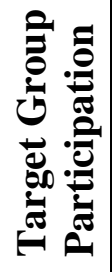 & 递 & 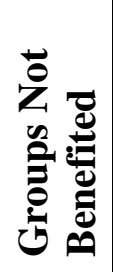 & 预 & 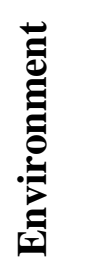 & 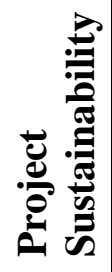 & 氙 \\
\hline 3670148 & $\mathrm{n}$ & $\mathrm{n}$ & $\mathrm{n}$ & $\mathrm{n}$ & $\mathrm{n}$ & $\mathrm{y}$ & $\mathrm{n}$ & $\mathrm{n}$ & $\mathrm{n}$ \\
\hline 3670153 & $\mathrm{y}$ & $\mathrm{n}$ & $\mathrm{n}$ & $\mathrm{n}$ & $\mathrm{n}$ & $\mathrm{n}$ & $\mathrm{n}$ & $\mathrm{y}$ & $\mathrm{n}$ \\
\hline 3670155 & $\mathrm{y}$ & $\mathrm{y}$ & $\mathrm{y}$ & $\mathrm{y}$ & $\mathrm{y}$ & $\mathrm{y}$ & $\mathrm{y}$ & $\mathrm{y}$ & $\mathrm{n}$ \\
\hline 3670158 & $\mathrm{n}$ & $\mathrm{n}$ & $\mathrm{y}$ & $\mathrm{n}$ & $\mathrm{n}$ & $\mathrm{n}$ & $\mathrm{y}$ & $\mathrm{n}$ & $\mathrm{n}$ \\
\hline 3830080 & $\mathrm{y}$ & $\mathrm{n}$ & $\mathrm{y}$ & $\mathrm{n}$ & $\mathrm{n}$ & $\mathrm{n}$ & $\mathrm{n}$ & $\mathrm{n}$ & $\mathrm{n}$ \\
\hline 3830086 & $\mathrm{y}$ & $\mathrm{n}$ & $\mathrm{y}$ & $\mathrm{y}$ & $\mathrm{n}$ & $\mathrm{y}$ & $\mathrm{n}$ & $\mathrm{n}$ & $y^{1,2}$ \\
\hline 3830111 & $\mathrm{n}$ & $\mathrm{n}$ & $\mathrm{n}$ & $\mathrm{n}$ & $\mathrm{n}$ & $\mathrm{y}$ & $\mathrm{y}$ & $\mathrm{n}$ & $\mathrm{n}$ \\
\hline 3860489 & $\mathrm{n}$ & $\mathrm{n}$ & $\mathrm{y}$ & $\mathrm{n}$ & $\mathrm{n}$ & $\mathrm{n}$ & $\mathrm{n}$ & $\mathrm{y}$ & $\mathrm{n}$ \\
\hline 3860490 & $\mathrm{y}$ & $\mathrm{n}$ & $\mathrm{y}$ & $\mathrm{y}$ & $\mathrm{n}$ & $\mathrm{n}$ & $\mathrm{y}$ & $\mathrm{y}$ & $y^{1}$ \\
\hline 3860495 & $\mathrm{y}$ & $\mathrm{n}$ & $\mathrm{y}$ & $\mathrm{y}$ & $\mathrm{y}$ & $\mathrm{y}$ & $\mathrm{y}$ & $\mathrm{y}$ & $\mathrm{n}$ \\
\hline 3910489 & $\mathrm{n}$ & $\mathrm{n}$ & $\mathrm{y}$ & $\mathrm{n}$ & $\mathrm{y}$ & $\mathrm{y}$ & $\mathrm{n}$ & $\mathrm{y}$ & $\mathrm{n}$ \\
\hline 3910491 & $\mathrm{n}$ & $\mathrm{n}$ & $\mathrm{n}$ & $\mathrm{n}$ & $\mathrm{n}$ & $\mathrm{n}$ & $\mathrm{n}$ & $\mathrm{y}$ & $\mathrm{n}$ \\
\hline 4930337 & $\mathrm{y}$ & $\mathrm{n}$ & $\mathrm{y}$ & $\mathrm{y}$ & $\mathrm{n}$ & $\mathrm{y}$ & $\mathrm{n}$ & $\mathrm{n}$ & $\mathrm{n}$ \\
\hline 4970302 & $\mathrm{n}$ & $\mathrm{n}$ & $\mathrm{n}$ & $\mathrm{n}$ & $\mathrm{n}$ & $\mathrm{n}$ & $\mathrm{n}$ & $\mathrm{y}$ & $\mathrm{n}$ \\
\hline 4970304 & $\mathrm{n}$ & $\mathrm{n}$ & $\mathrm{n}$ & $\mathrm{y}$ & $\mathrm{n}$ & $\mathrm{y}$ & $\mathrm{n}$ & $\mathrm{y}$ & $\mathrm{n}$ \\
\hline 4970311 & $\mathrm{n}$ & $\mathrm{n}$ & $\mathrm{y}$ & $\mathrm{n}$ & $\mathrm{n}$ & $\mathrm{n}$ & $\mathrm{y}$ & $\mathrm{n}$ & $\mathrm{n}$ \\
\hline 4970330 & $\mathrm{n}$ & $\mathrm{n}$ & $\mathrm{y}$ & $\mathrm{y}$ & $\mathrm{y}$ & $\mathrm{y}$ & $\mathrm{y}$ & $\mathrm{y}$ & $\mathrm{n}$ \\
\hline 4970342 & $\mathrm{n}$ & $\mathrm{n}$ & $\mathrm{y}$ & $\mathrm{n}$ & $\mathrm{n}$ & $\mathrm{n}$ & $\mathrm{n}$ & $\mathrm{n}$ & $\mathrm{n}$ \\
\hline 4970347 & $\mathrm{n}$ & $\mathrm{n}$ & $\mathrm{y}$ & $\mathrm{n}$ & $\mathrm{n}$ & $\mathrm{y}$ & $\mathrm{n}$ & $\mathrm{y}$ & $\mathrm{n}$ \\
\hline 4970352 & $\mathrm{n}$ & $\mathrm{n}$ & $\mathrm{y}$ & $\mathrm{y}$ & $\mathrm{y}$ & $\mathrm{y}$ & $\mathrm{n}$ & $\mathrm{n}$ & $\mathrm{n}$ \\
\hline 4970357 & $\mathrm{n}$ & $\mathrm{n}$ & $\mathrm{n}$ & $\mathrm{n}$ & $\mathrm{n}$ & $\mathrm{n}$ & $\mathrm{n}$ & $\mathrm{y}$ & $\mathrm{n}$ \\
\hline 4970368 & $\mathrm{n}$ & $\mathrm{n}$ & $\mathrm{n}$ & $\mathrm{n}$ & $\mathrm{n}$ & $\mathrm{y}$ & $\mathrm{n}$ & $\mathrm{n}$ & $\mathrm{n}$ \\
\hline $\begin{array}{c}\text { Total } \\
\text { Numbers }\end{array}$ & $\begin{array}{c}7 \mathrm{y} \\
15 \mathrm{n} \\
\end{array}$ & $\begin{array}{c}1 \mathrm{y} \\
21 \mathrm{n} \\
\end{array}$ & $\begin{array}{l}14 \mathrm{y} \\
8 \mathrm{n} \\
\end{array}$ & $\begin{array}{l}8 \mathrm{y} \\
14 \mathrm{n} \\
\end{array}$ & $\begin{array}{c}5 \mathrm{y} \\
17 \mathrm{n} \\
\end{array}$ & $\begin{array}{l}12 \mathrm{y} \\
10 \mathrm{n} \\
\end{array}$ & $\begin{array}{c}7 \mathrm{y} \\
15 \mathrm{n} \\
\end{array}$ & $\begin{array}{l}12 \mathrm{y} \\
10 \mathrm{n} \\
\end{array}$ & $\begin{array}{c}2 y \\
20 n \\
\end{array}$ \\
\hline
\end{tabular}

${ }^{1}$ Employment

${ }^{2}$ Small farmers identified 


\section{Socioeconomic impacts in Latin America and the Caribbean.}

Table 4.27 shows the results for the 22 projects conducted in Latin America and the Caribbean. The most frequently reported socioeconomic factor was gender (16 projects). Project sustainability was next with 15 projects reporting on it. None of the projects reported nutritional changes.

Table 4.27

Socioeconomic Impacts Evaluated for Latin America and the Caribbean Projects

\begin{tabular}{|c|c|c|c|c|c|c|c|c|c|}
\hline 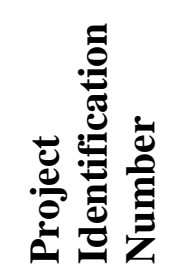 & 兽 & 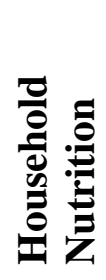 & 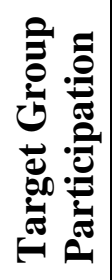 & 串 & 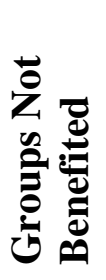 & 离 & 文 & 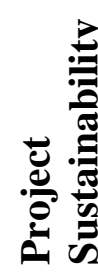 & 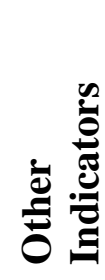 \\
\hline 5050008 & $\mathrm{n}$ & $\mathrm{n}$ & $\mathrm{n}$ & $\mathrm{n}$ & $\bar{n}$ & $\bar{y}$ & $\bar{y}$ & $\bar{y}$ & $\mathrm{n}$ \\
\hline 5150243 & $\mathrm{y}$ & $\mathrm{n}$ & $\mathrm{n}$ & $\mathrm{y}$ & $\mathrm{n}$ & $\mathrm{n}$ & $\mathrm{y}$ & $\mathrm{n}$ & $\mathrm{n}$ \\
\hline 5170159 & $\mathrm{n}$ & $\mathrm{n}$ & $\mathrm{n}$ & $\mathrm{y}$ & $\mathrm{y}$ & $\mathrm{n}$ & $\mathrm{y}$ & $\mathrm{y}$ & $\mathrm{n}$ \\
\hline 5180019 & $\mathrm{n}$ & $\mathrm{n}$ & $\mathrm{y}$ & $\mathrm{y}$ & $\mathrm{y}$ & $\mathrm{n}$ & $\mathrm{y}$ & $\mathrm{n}$ & $\mathrm{n}$ \\
\hline 5190307 & $\mathrm{y}$ & $\mathrm{n}$ & $\mathrm{n}$ & $\mathrm{n}$ & $\mathrm{n}$ & $\mathrm{n}$ & $\mathrm{n}$ & $\mathrm{n}$ & $\mathrm{n}$ \\
\hline 5190327 & $\mathrm{n}$ & $\mathrm{n}$ & $\mathrm{n}$ & $\mathrm{n}$ & $\mathrm{n}$ & $\mathrm{y}$ & $\mathrm{y}$ & $\mathrm{y}$ & $y^{1}$ \\
\hline 5200276 & $\mathrm{y}$ & $\mathrm{n}$ & $\mathrm{y}$ & $\mathrm{y}$ & $\mathrm{y}$ & $\mathrm{y}$ & $\mathrm{n}$ & $\mathrm{y}$ & $y^{2}$ \\
\hline 5200330 & $\mathrm{y}$ & $\mathrm{n}$ & $\mathrm{n}$ & $\mathrm{y}$ & $\mathrm{n}$ & $\mathrm{y}$ & $\mathrm{n}$ & $\mathrm{n}$ & $\mathrm{n}$ \\
\hline 5210216 & $\mathrm{y}$ & $\mathrm{n}$ & $\mathrm{n}$ & $\mathrm{n}$ & $\mathrm{n}$ & $\mathrm{y}$ & $\mathrm{y}$ & $\mathrm{y}$ & $\mathrm{n}$ \\
\hline 5220207 & $\mathrm{y}$ & $\mathrm{n}$ & $\mathrm{n}$ & $\mathrm{n}$ & $\mathrm{n}$ & $\mathrm{y}$ & $\mathrm{n}$ & $\mathrm{y}$ & $\mathrm{n}$ \\
\hline 5220246 & $\mathrm{y}$ & $\mathrm{n}$ & $\mathrm{n}$ & $\mathrm{n}$ & $\mathrm{n}$ & $\mathrm{y}$ & $\mathrm{y}$ & $\mathrm{n}$ & $\mathrm{n}$ \\
\hline 5220249 & $\mathrm{y}$ & $\mathrm{n}$ & $\mathrm{n}$ & $\mathrm{n}$ & $\mathrm{n}$ & $\mathrm{y}$ & $\mathrm{n}$ & $\mathrm{n}$ & $\mathrm{n}$ \\
\hline 5220252 & $\mathrm{n}$ & $\mathrm{n}$ & $\mathrm{n}$ & $\mathrm{n}$ & $\mathrm{n}$ & $\mathrm{y}$ & $\mathrm{n}$ & $\mathrm{y}$ & $\mathrm{n}$ \\
\hline 5220268 & $\mathrm{n}$ & $\mathrm{n}$ & $\mathrm{y}$ & $\mathrm{y}$ & $\mathrm{y}$ & $\mathrm{y}$ & $\mathrm{n}$ & $\mathrm{y}$ & $\mathrm{n}$ \\
\hline 5220292 & $\mathrm{n}$ & $\mathrm{n}$ & $\mathrm{n}$ & $\mathrm{n}$ & $\mathrm{n}$ & $\mathrm{y}$ & $\mathrm{y}$ & $\mathrm{y}$ & $\mathrm{n}$ \\
\hline 5270282 & $\mathrm{n}$ & $\mathrm{n}$ & $\mathrm{n}$ & $\mathrm{n}$ & $\mathrm{n}$ & $\mathrm{y}$ & $\mathrm{n}$ & $\mathrm{n}$ & $\mathrm{n}$ \\
\hline 5270293 & $\mathrm{n}$ & $\mathrm{n}$ & $\mathrm{n}$ & $\mathrm{n}$ & $\mathrm{n}$ & $\mathrm{n}$ & $\mathrm{n}$ & $\mathrm{y}$ & $\mathrm{n}$ \\
\hline 5270349 & $\mathrm{y}$ & $\mathrm{n}$ & $\mathrm{n}$ & $\mathrm{n}$ & $\mathrm{n}$ & $\mathrm{n}$ & $\mathrm{n}$ & $\mathrm{y}$ & $y^{1}$ \\
\hline 5320101 & $\mathrm{y}$ & $\mathrm{n}$ & $\mathrm{y}$ & $\mathrm{y}$ & $\mathrm{y}$ & $\mathrm{y}$ & $\mathrm{y}$ & $\mathrm{y}$ & $y^{3,4}$ \\
\hline 9365826 & $\mathrm{n}$ & $\mathrm{n}$ & $\mathrm{y}$ & $\mathrm{y}$ & $\mathrm{n}$ & $\mathrm{y}$ & $\mathrm{n}$ & $\mathrm{y}$ & $\mathrm{n}$ \\
\hline 9365826 & $\mathrm{n}$ & $\mathrm{n}$ & $\mathrm{y}$ & $\mathrm{y}$ & $\mathrm{n}$ & $\mathrm{y}$ & $\mathrm{n}$ & $\mathrm{y}$ & $\mathrm{n}$ \\
\hline 9365826 & $\mathrm{n}$ & $\mathrm{n}$ & $\mathrm{y}$ & $\mathrm{y}$ & $\mathrm{n}$ & $\mathrm{y}$ & $\mathrm{n}$ & $\mathrm{y}$ & $\mathrm{n}$ \\
\hline Total & $10 y$ & $0 \mathrm{y}$ & $7 y$ & $10 \mathrm{y}$ & $5 y$ & $16 \mathrm{y}$ & $9 y$ & $15 \mathrm{y}$ & $4 y$ \\
\hline Numbers & $12 n$ & $22 n$ & $15 \mathrm{n}$ & $12 \mathrm{n}$ & $17 \mathrm{n}$ & $6 n$ & $13 n$ & $7 \mathrm{n}$ & $18 n$ \\
\hline
\end{tabular}

${ }^{1}$ Employment

${ }^{2}$ Replication of project

${ }^{3}$ Commercial development

${ }^{4}$ Local participation in Development 


\section{CHAPTER V \\ FINDINGS AND CONCLUSIONS}

The results presented in this chapter identify the type and appropriateness of the evaluations of selected agriculturally-related science and technology based projects conducted by the United States Agency for International Development between 1985 and 1995. These projects were identified in the National Science Foundation project database (Pytlik, et al., 1997). This was a descriptive research study using content analysis according to the research methodology described in Chapter Three.

The chapter is divided into five sections. The first four sections correspond to the four study questions. The four study questions were: 1) What was evaluated? 2) What types of evaluations were completed and available to the public? 3) In what ways were the evaluations appropriate for determining socioeconomic impacts? 4) How might these evaluation results aid in the planning of future projects? The last section reports the research conclusions and recommendations for further study.

\section{Description of Projects}

The population for this research included 147 projects from around the world. On a world region basis 68 of the projects were conducted in Africa, 30 projects were in Asia, and 49 projects were in Latin America and the Caribbean (LAC). The total dollar value of these 147 projects was $\$ 2,324,974,995$. There were 94 projects (64\%) with at least one evaluation. The 94 projects had 226 evaluations that were published. The remaining 53 projects were not evaluated. The dollar value of these 53 projects totaled $\$ 331,093,995$, while the 94 projects with evaluations totaled $\$ 1,993,881,000$. When the per project average budget was compared for the two groups, those with evaluations totaled 3.4 times the dollar value as those without evaluations $(\$ 21,211,500$ versus $\$ 6,247,056)$. Thus, it was concluded that the larger a project's budget, the more likely the project was to be evaluated.

Among the world regions 25 (83\%) of the 30 projects conducted in Asia had at least one reported evaluation, while Africa had only 38 (55\%) projects out of 68 and LAC had 31 (63\%) projects out of 49. Projects conducted in Asia were evaluated 1.5 times 
more often than projects in Africa and 1.3 times more often than projects in Latin America and the Caribbean. A comparison between those projects with evaluations and those without evaluations by average dollar budgeted per project by world region followed the same trends as viewing the projects as a total group. Of the African projects that were evaluated compared to those that were not, the project budgets were more than double in value for those being evaluated (\$11 million versus \$5 million). However, in Asia the ratio was 2.5 to 1 (\$36 million versus $\$ 14$ million) and in LAC the ratio was 4.1 to 1 (\$22 million versus $\$ 5$ million).

\section{Study Question 1: What Was Evaluated?}

\section{Project Type}

Out of the 147 projects $82(56 \%)$ were concerned with agricultural production. Agricultural policy and marketing accounted for another 34 projects. Of the 82 projects that dealt with production, 69 involved plant production and 11 projects were concerned with animal or aquatic agriculture production.

When the project types were compared within their categories, the percentage of projects being evaluated varied from $56 \%$ for production types ( 82 total) to $83 \%$ for agricultural policy projects (18 total). A comparison of the project types revealed that all of the categories contained projects that were evaluated. The same observation was true for the subcategories of production types. Agronomic projects (55 total) were evaluated $52 \%$ of the time, while $80 \%$ of the aquaculture projects ( 5 total) were evaluated. At least $50 \%$ of each subcategory type project was evaluated.

\section{Project Objectives}

Objectives were evaluated in80 of the 94 projects. Reasons for not evaluating a particular objective ranged from the evaluation report not discussing this topic to USAID deciding that certain objectives should not be evaluated as discussed in Chapter 4. A comparison of the average dollar value of projects with or without their objectives evaluated revealed a difference of 4.5 million dollars ( $\$ 21.9$ million versus $\$ 17.4$ million). The percentage of projects with all their objectives evaluated between the world regions ranged from $92 \%$ in Africa to $88 \%$ in Asia to a low of $74 \%$ in LAC. Therefore, it 
was concluded that projects in LAC were not reviewed as often as projects conducted in Africa and Asia for having all of their project objectives evaluated.

\section{Unexpected Outcomes}

Unexpected outcomes are observations made by the evaluators and included as part of the evaluation report. Examples of these included: not anticipating political problems for a particular project to new technologies being adopted by farmers in a nontargeted village. Unexpected outcomes were noted in 18 of the $94(19 \%)$ projects with evaluations. Unexpected negative outcomes that were reported in 17\% (3 projects) of the projects, while $83 \%$ (15 projects) reported unexpected positive outcomes. Those evaluations reporting unexpected outcomes were also fairly close in their average project dollar value (\$17.5 million reporting and \$22.0 million not reporting). When unexpected outcomes were compared between world regions, $32 \%$ ( 8 of 25 projects) of the Asian projects reported this information, $19 \%$ (6 of 31 projects) of the LAC projects and $11 \%$ (4 of 38 projects)of the African projects.

\section{Economic or Efficiency Indicators}

Projects evaluated for either economic or efficiency indicators totaled 72 out of the 94 projects. Of the 22 projects which did not provide such data, only Project 4970311 included a reason. That report indicated that the evaluators had failed to provide an economic analysis. On a regional basis, economic or efficiency indicators were included in $90 \%$ of the African projects, $74 \%$ of the LAC projects and $60 \%$ of the Asian projects. The average dollar value per project was greater for projects without economic or efficiency indicators ( $\$ 25.5$ million) than for projects reporting economic indicators (\$19.8 million). Therefore, a higher average budget for a project did not increase the projects chances of being evaluated.

\section{Planned and Actual Process Evaluated}

As discussed in Chapter 2, the evaluation literature indicated the desirability of evaluating both the planned procedures of carrying out a project and the actual procedures used during the project. The planned process was evaluated in $79(84.0 \%)$ projects and $80(85.1 \%)$ of the projects evaluated the actual process. The difference between 
evaluating the planned process and the actual process varied in Asia by one project (23 planned, 24 actual). The percentage for projects with planned processes evaluated was $92 \%$ and for projects with actual processes evaluated 96\%. In Africa there were 34 of the 38 projects with planned processes evaluated and 32 of the 38 projects with actual processes evaluated. Both projects evaluated for planned process and actual process totaled 24 out of 31 projects in LAC. Therefore, it was found that projects that were evaluated for their planned process also were evaluated for their actual process.

When the average per project dollar value was compared between planned and actual processes being evaluated, very little difference was found between the categories. The average dollar value per project for planned processes being evaluated was $\$ 22.6$ million versus the actual processes being evaluated at $\$ 22.5$ million. Similarly, the average dollar value for projects without planned processes being evaluated was $\$ 14.0$ million versus actual processes not being reported at \$13.7 million. Therefore, it was concluded that projects with larger budgets were more likely to be reviewed for planned and actual project process.

\section{Evaluation Purpose and Procedures}

Projects that included evaluations with the purpose and methodology used by the evaluators totaled 89 out of 94 projects. When the data were evaluated by world region, Africa included the information for 33 of its 38 projects, Asia for 23 of its 25 projects and LAC for 27 of its 31 projects. The average budget per project for those not including this information was $\$ 14.9$ million. Projects that had evaluations which reported the evaluation's purpose and procedures averaged \$22.0 million per project or 1.5 times larger than those projects which had evaluations but did not include the purpose and procedures of the evaluation. Once again, it was concluded that projects with a larger budget included the purpose of the evaluation and the procedures used.

\section{Study Question 2: What Types of Evaluations Were Completed and Available to the Public?}

First, each project was categorized as either a formal or informal evaluation. Formal evaluations were conducted either by outside contractors or the evaluation division of USAID -Washington. Informal evaluations were conducted by the project's 
contractor or the in-country field office of USAID. Then each project was categorized as either an interim, final, or impact evaluation by the criteria discussed in chapters 2 and 3 . The data for each of these projects were also reviewed to see if their were differences between world region or project dollar budgeted. Total dollars for these 94 projects equaled $\$ 1,963,881,000$. Therefore, projects containing over $86 \%$ of the total dollars budgeted for the 147 projects were evaluated.

\section{Formal and Informal Evaluations}

There were 85 projects with 168 formal evaluations and 43 projects with 58 informal evaluations. Projects with both formal and informal evaluations totaled 34. In Africa 49 of the 80 evaluations were formal; Asia had 43 of its 56 evaluations as formal; and LAC had 76 of its 90 evaluations classified as formal. Additionally, the number of evaluations per project was similar among the world regions.

When all 94 projects were considered, both Asia and LAC had $71 \%$ of their projects with formal evaluations. Africa had $61 \%$ of its projects formally evaluated. Overall, $66 \%$ of the projects had formal evaluations and $34 \%$ had informal evaluations. The average per project dollar value for projects with a formal evaluation was $\$ 22,868,470$ as compared to $\$ 16,704,116$ for projects with informal evaluations. Thus, it was found that projects with formal evaluations averaged $37 \%$ more dollars per project than those with informal evaluations. Therefore, it was concluded that larger budgeted projects were more likely to be evaluated formally.

\section{Interim, Final, and Impact Evaluations}

Interim or midterm evaluations were reported for 67 projects and totaled 120 reports. Longer running projects could have more than one interim evaluation or occasionally, where corrections were needed, a follow-up evaluation was completed before the end of the project. Budget dollars per project averaged \$24.6 million.

Africa had 24 projects with 38 interim evaluations. Asia had similar numbers with 21 projects with 33 midterm evaluations. Latin America and the Caribbean totaled 22 projects with 49 interim evaluations. While Africa and Asia averaged 1.6 evaluations 
per project, LAC averaged 2.0 per project. Therefore, it was found that the per project average among world regions was similar.

Final evaluations conducted at the close of a project were reported for 64 projects and included 105 evaluations. Projects may have both an informal evaluation completed by the project contractor and a formal evaluation completed by an outside evaluation team. Additionally, some projects that encompassed many different aspects might have had two or more different final evaluation teams. Each team targeted to a specific sector and each of these reports were published (for example Project 6080196 or Project 6320228).

Africa and LAC had a similar number of evaluations reported with 42 for Africa and 40 for LAC. Asia had only 23 final evaluations, but the final evaluation to project ratios were very similar for the three regions (Africa 1.6, LAC 1.7, and Asia 1.5).

Therefore, it was found that the number of evaluations conducted per project did not vary among world regions.

There was only one impact evaluation reported. It was in LAC and was part of a project budgeted at $\$ 28.3$ million. Impact evaluations require that an evaluation be made some time after the conclusion of the project to evaluate long-term effects of the project. Due to this finding, it was concluded that impact evaluations were not being conducted at the project level.

\section{Study Question 3: In What Ways Were the Evaluations Appropriate for Determining Socioeconomic Impacts?}

The reports were analyzed for stakeholder involvement both as an inclusion in the project goals during the project design process and during or afterwards as part of the project evaluation. Also, the socioeconomic indicators of income, nutrition, targeted audience reached, groups that benefited and groups that did not benefit, gender equity, environmental, and project sustainability after project funding ceased were recorded. Several other types of socioeconomic indicators were also catalogued, which included employment, employability, and the reduction of rat bites within a household. In addition to reviewing for differences among world regions or project dollar budgeted, the data for each of the projects with socioeconomic impact evaluations were also reviewed to see if 
there were changes over time in the frequency of evaluations which included socioeconomic impacts.

\section{$\underline{\text { Stakeholder Involvement }}$}

Stakeholder involvement was concerned with the issue of whether or not the individuals who were the object of the project were included in the planning, execution, and evaluation of the project. Stakeholders were identified in 35 out of the 94 projects in the goals and/or objectives of the project proposal. While 53 projects did not indicate whether or not all of the stakeholders had been identified, six projects provided no information about the stakeholders. Thus, it was found that in only 35 of the 147 projects were stakeholders involved in developing the project.

Input from stakeholders during project evaluation was included in 44 projects (47\%). There were 40 projects that did not indicate whether or not all of the stakeholders had been included and 10 projects where specific groups were omitted in the evaluation (Table 4.21). When the data were filtered by world regions, the percentage of projects with all stakeholders included ranged from a low of $32 \%$ in LAC to a high of $64 \%$ in Asia. Africa had $47 \%$ of its projects with all of the stakeholders included in the evaluation. Projects conducted in Asia were twice as likely to include stakeholder input in their evaluation than projects evaluated in LAC.

The per project dollar value varied from \$10.4 million in Africa to \$35.6 million in Asia. However, when comparing the projects with all stakeholders included in the evaluation to those that were not included, the values between regions were very similar. The percentage of budgeted dollar value per project for those with stakeholder input included in the evaluation to those projects with either insufficient information to determine this criteria or identified groups were left out were $108.6 \%$ for Africa, $85.2 \%$ for Asia and $79.6 \%$ for LAC. Therefore, it was found that there was no relationship between the amount of the project budget and whether or not stakeholders were included in the evaluation. 


\section{$\underline{\text { Socioeconomic Impacts }}$}

Of the 147 projects, 94 projects were evaluated. Of the 94 projects evaluated, 72 projects were evaluated for at least one socioeconomic factor. Reviewing the data from a world region perspective, Africa had 28 projects evaluated for socioeconomic factors but on a percentage basis only $48 \%$ with socioeconomic evaluations. Asia and LAC had an equal number of projects evaluated (22) for socioeconomic impacts, however on a percentage basis Asia had $73.3 \%$ of its projects evaluated while LAC had only $44.9 \%$ of its projects evaluated. Therefore, it was found that less than one half of the projects evaluated in LAC and Africa included socioeconomic factors.

From a budget perspective $76 \%(\$ 1,769,195,000)$ of the dollars went to projects with at least one socioeconomic impact evaluated. For Africa there was only a small difference ( $\$ 11.0$ million versus $\$ 10.7$ million) between the average project budgets of those evaluated for socioeconomic impacts and those that were not evaluated. LAC revealed a larger difference with $\$ 27.1$ million for projects, which were evaluated, for socioeconomic indicators to $\$ 10.3$ million for those without evaluations. The largest budgeted difference was in Asia where those projects without socioeconomic evaluations averaged $\$ 8.1$ million and those with socioeconomic evaluations averaged $\$ 39.3$ million. Therefore, it was concluded that in Latin America and Asia the larger budgeted projects were the projects that were evaluated for socioeconomic impacts.

The effect of project completion dates was compared with those projects evaluated for socioeconomic impacts to determine if more current projects might be more frequently evaluated for socioeconomic impacts. Projects included in this research were active or completed during the years 1985 through 1995. The occurrence of projects with socioeconomic impact evaluations was divided into two groups: those with project completion dates during 1990 or before and those with project completion dates in 1991 or after. For the 72 projects having a socioeconomic component evaluated 25 occurred during 1990 or before and 47 projects occurred during 1991 or after. Comparing projects with socioeconomic evaluations to all projects with evaluations, 69.4\% were in the 1990 and before group and $81.0 \%$ were in the 1991 and after group. Therefore, it was 
concluded that the frequency of evaluations with socioeconomic indicators increased over time.

Making the same comparison by world regions, projects with socioeconomic impact evaluations increased in LAC by $450 \%$ (4 projects to 18 projects). Asia and Africa had smaller but similar increases with Asia increasing by $144 \%$ (9 to 13 projects) and Africa increasing by $133 \%$ (12 to 16 projects). On a total project basis, and also viewed across the world regions, the number of projects evaluated for socioeconomic impacts increased from the 1990 and before group to the 1991 and after group..

\section{Project sustainability.}

Project sustainability was evaluated in 49 projects. (Sustainability was used in the sense of: "can the project continue after USAID funding ceases?" and not in reference to the technology being utilized.) There were 22 such projects in Africa, 12 in Asia, and 15 in LAC. From a budgeted dollar viewpoint, Africa and LAC average budgets were similar between those projects evaluated for sustainability and those projects not evaluated for it. The difference in Africa was $\$ 11.0$ million to $\$ 10.8$ million and in LAC it was $\$ 22.4$ million to $\$ 22.1$ million. However, in Asia the average project budgets were much larger for those projects being evaluated for project sustainability (\$54 million versus \$18 million). Therefore, only in Asia were projects with a larger budget more likely to be evaluated for project sustainability.

Comparing projects evaluating project sustainability by project completion dates revealed no change for Asia. Six projects were evaluated for this factor in the 1990 and before group and 6 projects were evaluated in the 1991 and after group. Africa had a large increase ( 8 projects to 14 projects) and LAC had an even larger increase ( 2 projects to 13 projects). While no change was found for Asia, both Africa and LAC had large increases in more recent times.

\section{Gender equity.}

Gender equity was evaluated in 47 projects with a total project budget of $\$ 1.06$ billion. Nineteen of those projects were in Africa, 16 in LAC, and 12 in Asia. A comparison of average project budget between projects that were evaluated and those that 
were not was made to determine if the amount of the project budget influenced whether or not a project was evaluated for gender equity. In Africa and Asia there were similar differences with Africa averaging \$10.9 million for those evaluated to \$10.9 for those not evaluated. In Asia the difference was an average budget of $\$ 36.3$ million for those with evaluations for gender equity to $\$ 38.8$ million for those projects without evaluations for gender equity. Therefore, it was concluded that whether or not a project was evaluated for gender equity was not influenced by the project budget.

When gender equity was compared by project completion dates, results similar to project sustainability were found. The number of projects conducted in Asia with evaluations for gender equity remained the same between the two groups (6 projects in the 1990 and before group and 6 projects in the 1991 and after group). There was a small increase in Africa with 8 projects with evaluations which included gender equity in the 1990 and before group and 11 projects in the 1991 and after group. In LAC there was a large increase over the same time span. The number of projects increased from two in the 1990 and before group to 14 in the 1991 and after group. Only in projects conducted in LAC did there appear to be an increase over time. However, one should keep in mind that overall only 47 out of 147 projects were evaluated for gender equity.

\section{Target group participation.}

Target group participation was evaluated in 28 of the 94 projects that were evaluated. Africa and LAC each had 7 projects evaluated for this socioeconomic impact and Asia had 14 projects evaluated. The total budgeted project value for these 28 projects was $\$ 654.9$ million versus those not evaluated having a total project budget of $\$ 1,339.0$ million. Less than one-third of the project dollars included an evaluation for target group participation.

The average dollars per project of those projects evaluated for target group participation was less in Africa and LAC than those projects that were not evaluated for target group participation. In Africa the average per project budget was \$6.9 million for those projects evaluated for this factor versus $\$ 11.8$ million for those projects not evaluated for target group participation. In LAC the average per project budget was \$13.6 
million for those evaluated for this factor to $\$ 24.4$ million for those projects not evaluated. In Asia the value of those projects being evaluated for target group participation exceeded those projects without evaluations for this factor: $\$ 36.5$ million to $\$ 34.3$ million. Therefore, it was found that based on average project budget, the higher the dollar amount the more likely the projects in LAC and Africa were to exclude target group participation in their evaluation.

The number of projects, which were evaluated for target group participation, increased over time in all three of the world regions involved in the study. Projects in Africa increased from three projects in the group 1990 and before to four projects in the group 1991 and after. In Asia there was a similar increase from 6 projects in the group 1990 and before to 8 projects in the group 1991 and after. LAC increased from one project in the group 1990 and before to 6 projects in the group 1991 and after. So, while the total number of projects reporting on target group participation in the world regions was small, the number of projects evaluated per region were found to be increasing over time.

\section{Groups who did and did not benefit.}

Determining which groups benefited from a project and which groups did not benefit would seem like the opposite sides of the same coin. However, 30 projects were evaluated for groups which did benefit and 18 projects were evaluated for groups which did not benefit. In Africa thee were 12 projects evaluated for groups that did benefit and 8 projects evaluated for groups that did not benefit. In LAC 10 projects were evaluated for groups which benefited and five projects were evaluated for groups that did not benefit. Eight projects in Asia were evaluated for groups which benefited and five projects were evaluated for groups who did not benefit. Therefore, it was found that projects were more likely to be evaluated for the benefit they provided, while ignoring their possible harm.

Considering projects with evaluations for groups which benefited, only in LAC did the average budget per project differ greatly between those projects evaluated for groups who benefited and those projects which were not evaluated for groups who 
benefited. The average dollar value for those projects with evaluations was $\$ 12.4$ million versus $\$ 27.0$ million for those projects not being evaluated for groups that benefited. The difference in Africa was $\$ 11.7$ million for the average budget per project for those projects which were evaluated for groups which benefited to $\$ 10.5$ million per project budget for those projects which had evaluations which were not evaluated for groups which benefited. In Asia the difference was \$33.0 million per project budget for those with evaluations for groups which benefited to $\$ 36.8$ million per project budget for those not evaluating for groups who benefited. Therefore, it was found that only in LAC did the project budget influence whether or not a project was evaluated for benefits.

A comparison of projects evaluated over time for groups who benefited increased for two world regions and decreased for the third region. Africa increased from 5 projects in the group 1990 and before to 7 projects in the 1991 and after group. Similarly, LAC increased from three projects in the group 1990 and before to 7 projects in the group 1991 and after. In Asia the group 1990 and before had five projects and the group 1991 and after had three projects. Therefore, it was found that viewed over time, the number of projects being evaluated changed little.

For those projects evaluated for groups who did not benefit, the average budget per project was $\$ 17.6$ million. The average budget per project for those projects which did not evaluate for groups who did not benefit was \$22.9 million. On a world region basis the difference between those evaluated and those not evaluated was close for Africa and Asia (\$11.7 million to \$10.5 million and \$33.0 million to \$36.8 million). In LAC the difference was $\$ 12.4$ million for those projects evaluated for groups who did not benefit to $\$ 27.0$ million for those not evaluated for this factor. It was found that higher budgeted projects were more likely to not evaluate for this factor.

When the projects evaluated for groups who did not benefit were reviewed for when they occurred, In Asia there were fewer projects evaluated for this factor in the 1991 and after group (3 projects) than in the 1990 and before group ( 2 projects). African project numbers remained the same with four projects in each time group. LAC increased with one project in the group 1990 and before and 4 projects in the 1991 and after. Thus, 
except for LAC the number of projects being evaluated for groups that did not benefit did not increase over time.

\section{Income and/or living standard.}

Income and/or living standards were another socioeconomic impact indicated for evaluation. Twenty-five projects were evaluated for this factor, 10 in LAC, 8 in Africa and 7 in Asia. The average project budget for those projects evaluated for income or living standard changes exceeded the average project budget for those not evaluated for this factor in each of the three world regions. In Africa the difference was \$17.4 million per project for those which were evaluated for income impacts to $\$ 9.2$ million per project for those which were not evaluated for income impacts. The difference in Asia was \$41.8 million per project for those, which were evaluated for income impacts to \$33.1 million per project for those, which were not evaluated for income impacts. In LAC the difference was $\$ 32.0$ million per project for those which were evaluated for income impacts to $\$ 17.6$ million per project for those which were not evaluated for income impacts. Thus, it was found that the projects with larger budgets were more often selected to be evaluated for changes in income or living standards.

Over time, the number of projects evaluated for changes in income or living standard increased in each world region. Each world region had three projects which were evaluated for income changes in the group 1990 and before. Africa increased to five projects which were evaluated for this factor in the group 1991 and after, Asia increased to four projects and LAC increased to 7 projects. Thus, over time the number of projects evaluated for changes in income or living standards was increasing.

\section{Environment.}

Some type of environmental evaluation was reported in 24 projects. These 24 projects represented a budgeted allotment of $\$ 612.3$ million. The 24 projects were almost evenly spread among the three world regions with 9 in LAC, 8 in Africa, and 7 in Asia.

When the projects were divided into two chronological groups, both Asia and Africa had an almost equal number of projects in the 1990 and before group versus the 1991 and after group. Africa had four in the 1990 and before group and four in the 1991 
and after group, while Asia had three in the before group and four in the after group. LAC had the largest difference with one in the 1990 and before group and 8 in the 1991 and after group.

\section{Nutrition.}

The literature revue identified nutrition as an easily identifiable socioeconomic indicator (Casley \& Kumar, 1987; Koblinsky, Timyan, \& Gay, 1993) but only three projects were evaluated for this factor. Two of the projects were in Africa and the other one was in Asia. The three projects had a total budget of $\$ 54.0$ million. With only three projects there was no time line analysis attempted.

\section{Study Question 4: How Might These Evaluation Results Aid In the Planning of Future Projects?}

The evaluation results that were part of this research could aid planners by avoiding potential problems and building on discovered strengths. The failures of the early efforts at transferring agricultural technologies to LDCs could have been avoided with adequate evaluations (Pearse, 1980; Wolf, 1986). Eckman (1994) showed how evaluating projects for socioeconomic factors would allow changes, which might have kept productive projects viable. Lessons from evaluations at the end of a project can be used to adjust strategies for future projects plus allow funding agencies to make adjustments in other currently ongoing projects when the situations were similar enough (Casley \& Kumar, 1987).

However, for evaluation results to be beneficial, the results must be utilized. Gow and Morss (1988; see also Cernea, 1991) pointed out the necessity for planners to make use of the information generated by the evaluation of third world development projects. Assuming that the information is considered and put to use then past experiences can be used to improve the effectiveness of future projects.

The evaluator's findings have pointed out potential problems and cultural barriers that must be accounted for if future projects are to be successful. Projects like 3670148 or 3670155 in Nepal indicated the cultural barriers encountered in trying to help women secure advanced degrees or hiring them to be agricultural extension agents. Evaluators in 
Honduras (Project 5220268) noted that the country's agricultural arena was dominated by men while women, who were more involved at the subsistence farming level, were not reached by the project. Therefore, it was concluded that planners need to consider this information if one of the targeted groups is to be women.

Evaluations that are reviewed with care can also point to potential problems even if the evaluators do not point out a particular problem. For example, the results of Project 3860490 in India should be tempered with the fact that the evaluators interviewed only men for their evaluation of the project.

Projects which are compatible with the indigenous culture are more likely to be successful (Kottak, 1991). Reviewing evaluations of projects attempted within that country or community might forewarn developers of potential problems within that culture.

Evaluators of six projects reviewed for this research indicated that the project was failing or failed because of unrealistic project designs or goals. It was concluded that a review of these projects would aid future planners in developing realistic designs for their project. [See Projects 3910489, 4970347, 6150221, 5190307, 5220268, and 6640343]

The results of this research also demonstrated the importance of securing baseline data for future evaluations of a project. Project 6150221 in Kenya and Project 5190307 in El Salvador noted the impossibility of adequately evaluating the project because the agreed upon baseline data that was to be gathered was never secured.

If the usefulness and effectiveness of project evaluations is to increase, then planners must give more attention to designing projects which are sociocultural acceptable and gathering the baseline data to enable realistic evaluations to be conducted.

\section{General Conclusions and Recommendations}

\section{Conclusions}

The population for this research consisted of 147 projects conducted in LDCs. Sixty-eight projects were conducted in Africa, 49 projects were conducted in Latin America, and 30 projects were conducted in Asia. The total dollars budgeted for these projects were $\$ 2.3$ billion. Of the 147 projects, 94 of these projects (64\%) were evaluated 
and accounted for $\$ 1.9$ billion dollars ( $83 \%$ of the total dollars). The average per project budget between those projects with evaluations and those projects without evaluations differed by $\$ 15.0$ million. The average project budget for those with evaluations was $\$ 21.2$ million. Thus, the larger a project's budget, the more likely the project was to be evaluated.

A comparison of projects with evaluations of average dollars budgeted per project among world regions revealed a wide disparity among regions. Africa's per project average was \$10.9 million. LAC's per project average was \$22.3 million and Asia's per project average was $\$ 35.6$ million. This was a $\$ 24.7$ million difference in per project budgets between those projects conducted in Africa and those projects conducted in Asia. While only $55.9 \%$ of the projects conducted in Africa were evaluated, $83.3 \%$ of the projects conducted in Asia were evaluated.

When projects with or without evaluations were compared by the type of agricultural technology that was to be transferred, fifty percent or more of each of the project types had been evaluated. Projects with all of their objectives evaluated totaled 80 out of 94 projects. On a world region basis, the project objectives for projects in LAC were not evaluated as often as projects conducted in Africa or Asia.

While in only 18 projects were evaluations with unexpected outcomes noted, 72 projects included evaluations with economic or efficiency indicators. Surprisingly, the average budget per project was larger for projects which did not evaluate economic indicators than those that did evaluate economic indicators. The average budget for those projects without economic indicators in their evaluations was $\$ 25.5$ million versus $\$ 19.8$ million for those projects with economic indicators included in their evaluation. Therefore, it was concluded that the larger budgeted projects were more likely to not evaluated for these impacts.

The planned project process was evaluated in $79(84.0 \%)$ of the projects and the actual project process was evaluated in $80(85.1 \%)$ of the projects. Projects that were evaluated for their planned process also were evaluated for their actual process. There were very small differences in the average project budget between those projects with this 
type of evaluation and those without it. Therefore, if the planned project process was evaluated, evaluators also evaluated the actual process.

Evaluations which included the purposes and procedures of the evaluation totaled 89 out of the 94 projects that were evaluated. There were 226 evaluations of all types completed and reported for the 94 projects. While 85 projects had formal evaluations, 43 projects had informal evaluations. Some projects had more than one formal or informal evaluation and a few had both formal and informal evaluations. A comparison of average budgets per project between those with formal evaluations and those with informal revealed that those projects with formal evaluations had an average budget of $\$ 22.9$ million. Those projects with informal evaluations had an average per project budget of $\$ 16.7$ million. Therefore, it was found that projects with larger budgets were more often evaluated formally.

Of the 94 projects with evaluations, 67 projects had interim evaluations. The three world regions shared equally among the projects with interim evaluations. In Africa there were 24 projects, in LAC 22 projects, and in Asia 21 projects with interim or midterm evaluations.

Final evaluations were conducted for 64 projects. While projects with final evaluations in Africa and LAC were similar in number (Africa with 42 and LAC with 40), Only 23 projects with final evaluations were in Asia.

Since there was only one project with an impact evaluation, the research showed that impact evaluations were not being conducted at the project level.

Stakeholder involvement was identified as critical to a projects success, but only $24 \%$ (35 projects) of the projects identified the stakeholders in the project's goals. Additionally, only 44 projects (30\%) included input from all stakeholders in the evaluation. When viewed from a world region perspective, projects conducted in Asia were twice as likely to include stakeholder input in their evaluation. Interestingly, only the average per project budget for Africa for stakeholder involvement in the evaluation process exceeded the average budget for those projects without stakeholder involvement. 
It was concluded that the smaller projects were more likely to include stakeholder involvement.

Of the 94 projects evaluated, 72 projects were evaluated for at least one socioeconomic impact. Asia had the highest percentage of projects evaluated for socioeconomic impacts. The range for the percentage of projects with this type of evaluation was: $73 \%$ for Asia, $48 \%$ for Africa, and $45 \%$ for LAC. Therefore, it was found that less than one half the projects evaluated in LAC or Africa included socioeconomic impacts.

From a budget perspective, $76 \%$ or $\$ 1,769.2$ million of the total project budget included projects which were evaluated for socioeconomic impacts. From a world region perspective projects from Asia had the largest difference between projects with socioeconomic evaluations and those without socioeconomic evaluations. The average project budget for Asia was $\$ 39.3$ million for projects with socioeconomic evaluations and only \$8.1 million for those projects without socioeconomic evaluations. In both LAC and Asia the larger budgeted projects were evaluated for socioeconomic indicators. Therefore, it was concluded that projects with larger budgets were more often evaluated for socioeconomic indicators than were lesser funded projects.

Two time-referenced groups were set up to compare the changes in projects being evaluated for socioeconomic impacts. One group included all the projects with completion dates of 1990 or before. A second group included all the projects with completion dates of 1991 and after. The number of projects evaluated over time increased from 25 projects in the earlier group to 47 projects in the latter one. A comparison of this time factor by world region revealed that in LAC there was a $450 \%$ increase (4 projects in the 1990 and before group to 18 projects in the 1991 and after group). Asia and Africa showed a more modest increase with Asia increasing from 9 projects in the before group to 13 projects in the after group and Africa increasing from 12 projects in the before group to 16 projects in the after group. Therefore, it was concluded that over time there were an increasing number of projects being evaluated for socioeconomic indicators. 
Project sustainability (49 projects), gender equity (47 projects), target group participation (28 projects), groups who benefited (30 projects), groups who did not benefit (18 projects), income and/or living standard (25 projects), environment (24 projects), and nutrition ( 3 projects) were all socioeconomic impacts for which all the project evaluations were reviewed. Therefore, it was concluded that even though most of the projects involved agricultural production technologies, the impact on the nutritional intake on these households was not being evaluated.

In all of these socioeconomic factors, projects in LAC had the largest increases over time. For project sustainability there were two projects in the 1990 and before group and 13 projects in the 1991 and after group. Similarly, for gender equity there were two projects in the before group and 14 in the after group. For several of these factors LAC had only one project in the 1990 and before group but showed an increase in the 1991 and after group: target group participation - 6 projects, groups who did not benefit - 4 projects, and environment -8 projects. Therefore, it was concluded that the number of projects in LAC being evaluated for socioeconomic indicators was increasing.

Projects conducted in Asia indicated much smaller increases and even decreases for these socioeconomic factors when compared over time. For projects evaluated for project sustainability and gender equity the number of projects in the 1990 and before group was the same as the 1991 and after group. Projects evaluated for target group participation increased from 6 projects in the 1990 and before group to 8 projects in the 1991 and after group. When projects evaluated for groups who benefited were compared over time, the number of projects in Asia declined from 5 projects in the 1990 and before group to three projects in the 1991 and after group. Projects conducted in Africa indicated increases or the same number of projects in either time frame, whether the projects were grouped in the 1990 and before group or the 1991 and after group. It was concluded, therefore, that the number of projects being evaluated for socioeconomic indicators in Asian and Africa was not increasing over time.

Evaluations which include socioeconomic impacts would be useful to planners in fine tuning future development projects. Additionally, interim evaluations allow the 
management team to fine tune the project process or cease the project if it's doing harm, without waiting to the end of a project to determine what has happened.

Three emergent themes were noted: First, 19 different projects had evaluations which noted that a major problem was too many management changes during the project. For example, Project 5220207 evaluators noted that there were three directors and 6 project officers from 1984 to 1994. Project 3860489 had 6 different chief engineers. Secondly, six projects had an unrealistic project design. Third, six projects had evaluators who noted that many of the project objectives could not be evaluated because baseline data had not been collected.

\section{$\underline{\text { Summary }}$}

Based on this research less than one half of the projects reviewed were evaluated for socioeconomic impacts. Better news was that $87 \%$ or $\$ 2.0$ billion of the total dollars budgeted went to projects which were evaluated and of that amount \$1.8 billion dollars went to projects with evaluations which included socioeconomic indicators. Major points discussed included:

- $\quad$ Only one project out of 147 projects $(0.68 \%)$ had an impact evaluation.

- $\quad$ Ninety-four projects out of 147 projects had at least one evaluation.

- $\quad$ Seventy-two projects out of 147 projects had an evaluation that included an assessment for a socioeconomic impact.

- $\quad$ Eighty-five out of 147 projects had formal evaluations.

- $\quad$ Sixty-seven projects out of 147 projects had interim evaluations.

- $\quad$ Sixty-four projects out of 147 projects had final evaluations.

- $\$ 2.0$ billion of the total project's budgets of $\$ 2.3$ billion were allotted to projects which were evaluated.

- $\quad$ The average project budget with an evaluation in Asia was \$35.6 million as compared to Africa with $\$ 10.9$ million per project and LAC with $\$ 22.3$ million per project. 
- $\quad 78.3 \%$ of the total project's budgets or $\$ 1.8$ billion out of a total of $\$ 2.3$ billion were allotted to projects with evaluations that included socioeconomic impacts.

- $\quad$ Project sustainability (49 projects) and gender equity (47 projects) were the most often included socioeconomic indicators in a project's evaluation.

- $\quad$ Only 3 projects included nutrition as a socioeconomic indicator in their evaluation.

- $\quad$ Compared over time, LAC indicated the largest increase for the inclusion of socioeconomic impacts in a project's evaluation.

- $\quad$ Evaluations of 19 projects noted project problems due to frequent changes in management.

- Evaluations also indicated two problems encountered when attempting to evaluate a project were unrealistic project designs or goals and a lack of baseline data on which to compare the project's objectives.

\section{$\underline{\text { Recommendations for Further Study }}$}

How thoroughly were projects being evaluated between 1985 and 1995? This research indicated that a large proportion of the projects based on total allotted dollars were being evaluated. It did not address the question of the quality of the evaluations. The researcher noted some evaluations that purported to have interviewed all stakeholders, yet the list of interviewees listed only individuals with government or business titles or there were no women farmers on the list. Therefore, it was recommended that a metaevaluation be conducted to increase the information available on the quality of evaluations being conducted at the project level in third world countries.

Are more projects evaluated in Asia because Singapore and Hong Kong were more desirable destinations to visit than ports of call on the way to South America or Africa? Therefore, it was recommended that policies and decisions on which projects are evaluated be reviewed for biases. 
Another area not addressed by this study is how many of the projects are part of a political settlement and how many are designed basically to aid the poor people of a particular country? Therefore it was recommended that a review of projects be made to determine the effect of foreign policy on the decisions of which projects for which countries are funded. 


\section{BIBLIOGRAPHY}

Abelson, P. (1996). Project appraisal and valuation of the environment. London: Macmillan Press.

Ary, D., Jacobs, L., \& Razavieh, A. (1996). Introduction to research in education (5th Ed.). Ft. Worth, Texas: Harcourt Brace College.

Beaudoux, E., de Crombrugghe, G., Douxchamps, F., Gueneau, M., \& Nieuwkerk, M. (1992). Supporting development action: From identification to evaluation. London: Macmillan Press.

Beneria, L. \& Feldman, S. (Eds.). (1992). Unequal burden: Economic crises, persistent poverty, and women's work. Boulder, Colorado: Westview Press.

Berhie, G. (1984/1986). The multi-dimensional developmental evaluation model: A conceptual schema for evaluating social programs proposed for third world countries. Dissertation Abstracts International, 44-04A, 960. (University Microfilms International No. 8418612)

Bernsten, R. \& Staatz, J. (1992, October). The role of subsector analysis in setting research priorities. Paper presented at USAID sponsored Symposium on the Impact of Technology on Agricultural Transformation in Africa, Washington, D.C.

Bogert, C. (1995, May 29). More bang for the buck. Newsweek, 50.

Borg, W. \& Gall M. (1989). Educational research: An introduction (Fifth Edition). White Plains, NY: Longman.

Bowden, P. (1988). National monitoring and evaluation: Development programs in the third world. Aldershot, England: Gower Publishing Company.

Boyd, N., Jr. \& Windsor, R. (1993, Fall). A meta-evaluation of nutrition education intervention research among pregnant women. Health Education Quarterly, 20, $327-345$.

Brown, L. R. (1977). Population and affluence: Growing pressures on world food resources. In R. D. Stevens (Ed.), Tradition and dynamics in small-farm agriculture: 
Economic studies in Asia, Africa, and Latin America (pp. 25-53). Ames, Iowa: The Iowa State University Press.

Brown, L. R., Flavin, C., French, H., Abramovitz, J., Bright, C., Gardner, G., McGinn, A., Renner, M., Roodman, D., \& Starke, L. (1997). State of the world: A Worldwatch Institute report on progress toward a sustainable society. New York: W. W. Norton.

Burkey, S. (1993). People first: A guide to self-reliant participatory rural development. London: Zed Books.

Carvalho, S. \& White, H. (1994). Indicators for monitoring poverty reduction (World Bank discussion papers; 254). Washington, D. C.: World Bank.

Casley, D. \& Kumar, K. (1987). Project monitoring and evaluation in agriculture. Baltimore: The Johns Hopkins University Press.

Cernea, M. (1987, Summer). Farmer organizations and institution building for sustainable development. Regional Development Dialogue, 8, 1-19.

Cernea, M. (Ed.) (1991). Putting people first: Sociological variables in rural development (2nd ed.). Washington D. C.: The International Bank for Reconstruction and Development/ World Bank (Oxford University Press).

Chambers, D., Wedel, K., \& Rodwell, M. (1992). Evaluating social programs. Boston: Allyn and Bacon.

Chambers, R. (1991). Shortcut and participatory methods for gaining social information for projects. In M. M. Cernea (Ed.), Putting people first: Sociological variables in rural development (2nd ed.) (pp. 515-537). Washington, D. C.: The World Bank / Oxford University Press.

Chavas, J. (1992). Issues of risk and public goods: Implications for technology development. Unpublished manuscript, University of Wisconsin, Madison.

Clayton, E.\& Petry, F. (1981). Monitoring systems for agricultural and rural development projects. Rome: Food and Agriculture Organization of the United Nations. 
Clayton, E.\& Petry, F. (1983). Monitoring systems for agricultural and rural development projects, Volume 2. Rome: Food and Agriculture Organization of the United Nations.

Cook, C. (1991). Social analysis in rural development projects. In M. M. Cernea (Ed.), Putting people first: Sociological variables in rural development (2nd ed.) (pp. 397428). Washington, D. C.: The World Bank / Oxford University Press.

Cummings, R., Dinar, A., \& Olson, D. (1996). New evaluation procedures for a new generation of water-related projects (World Bank technical papers; 349). Washington, D. C.: World Bank.

Curry, S. \& Weiss, J. (1993). Project analysis in developing countries. London: Macmillan Company.

de Leon, P. (1997). The evaluation of technology R\&D: A continuing dilemma. (Report No. CSE-R-179). Los Angeles: California University, Center for the Study of Evaluation. (ERIC Document Reproduction Service No. ED 218 307)

Derry, T. \& Williams, T. (1960/1993). A short history of technology: From the earliest times to A.D. 1900. New York: Dover Publications.

Eckman, K. (1994). Avoiding unsustainability in natural resources projects in developing countries: The precautionary monitoring approach (Doctoral dissertation, University of Minnesota, 1994). Dissertation Abstracts International, 56-01B, 13.

Eicher, C. K. \& Staatz, J. M. (1984). Agricultural development in the third world. The Johns Hopkins University Press.

Food and Agriculture Organization of the United Nations (1989). The design of agricultural investment projects: Lessons from experience. Rome: Author.

Food and Agriculture Organization of the United Nations (1993). Guidelines for the design of agricultural investment projects. Rome: Author.

Food and Agriculture Organization of the United Nations (1993). Science and technology in the work of FAO. Rome: Author. 
Gay, L. (1992). Educational research: Competencies for analysis and application (4th Ed.). New York: Macmillan Publishing.

Glaeser, B. (Ed.). (1987). The green revolution revisited. London: Allen \& Unwin.

Gow, D. \& Morss, E. (1988, No. 12). The notorious nine: Critical problems in project implementation. World Development, 16, 1399- 1418.

Gravetter, F., \& Wallnau, L. (1996). Statistics for the behavioral sciences (4th Ed.). St. Paul, MN: West Publishing.

Guba, E. \& Lincoln, Y. (1982). Epistemological and methodological bases of naturalistic inquiry. In Madaus, G., Scriven, M., \& Stufflebeam, D. (Eds.), Evaluation models: Viewpoints on educational and human services evaluation (pp. 311-333).

Boston: Kluwer-Nijhoff Publishing. (Reprinted from Educational Communications and Technology Journal, 30, No. 4, Winter 1982).

Gunawardena, A. (1987, Summer). Comment [Review of the article "Farmer organizations and institution building for sustainable development"]. Regional Development Dialogue, 8, 20-23.

Hayami, Y. \& Ruttan, V. (1971/1985). Agricultural development. Baltimore: The Johns Hopkins University Press.

Hinkle, D., Wiersma, W., \& Jurs, S. (1994). Applied statistics for the behavioral sciences (3rd Ed.). Boston: Houghton Mifflin.

ICRISAT (1980). Proceedings of the international workshop on socioeconomic constraints to development of semi-arid tropical agriculture, 19-23 February 1979, Hyderabad, India. Patancheru, A. P., India: International Crops Research Institute for the Semi-Arid Tropics.

Jacobson, J. L. (1992). Gender bias: Roadblock to sustainable development (Worldwatch Paper 110). Washington, D. C.: Worldwatch Institute. 
Joint Committee on Standards for Educational Evaluation (1994). The program evaluation standards: How to assess evaluations of educational programs (2nd edition). Thousand Oaks, California: Sage Publications.

Karl, M. (1995). Women and empowerment: Participation and decision making. London: Zed Books.

Koblinsky, M., Timyan, J., \& Gay, J. (Eds.). (1993). The health of women: A global perspective. Boulder, Colorado: Westview Press.

Korten, D. C. (1995). When corporations rule the world. West Hartford, Connecticut: Kumarian Press, Inc. \& San Francisco: Berrett-Koehler Publishers.

Kottak, C. (1991). When people don't come first: Some sociological lessons from completed projects. In M. M. Cernea (Ed.), Putting people first: Sociological variables in rural development (2nd ed.) (pp. 431-466). Washington, D. C.: The World Bank / Oxford University Press.

Krejcie, R. \& Morgan, D. (1970). Determining sample size for research activities. Educational and Psychological Measurement, 30, 607-610.

Kumar, K. (Ed.). (1993). Rapid appraisal methods. Washington, D. C.: World Bank.

Leaf, M. J. (1984). Song of hope: The green revolution in a Panjab village. New Brunswick, New Jersey: Rutgers University Press.

Lewis, J. P. \& Kallab, V. (Eds.) (1986). Development strategies reconsidered. Washington, D. C.: Overseas Development Council (New Brunswick, New Jersey: Transaction Books).

Madaus, G., Scriven, M., \& Stufflebeam, D. (Eds.). (1983). Evaluation models: Viewpoints on educational and human services evaluation. Boston: Kluwer-Nijhoff Publishing.

Malhotra, R. (1987). Preface. In D. Casley \& K. Kumar, Project monitoring and evaluation in agriculture (pp. ix-xi). Baltimore: The Johns Hopkins University Press. 
Mayeske, G. (1991). Program design: An evaluation approach. Washington, DC: Extension Service, United States Department of Agriculture.

Medard, K. (1993). Economic evaluation of the northeast rural development project in Ituri, Zaire. Unpublished doctoral dissertation, West Virginia University, Morgantown.

Mellor, J. (1995, October). [Review of the books Structural and rural development in the third world and The state of world rural poverty: An inquiry into its causes and consequences]. Economic Development and Cultural Change, 44, 219-223.

Mish, F., et al. (Eds.). (1994). The Merriam-Webster dictionary. Springfield, MA: Merriam-Webster.

Mitchell, B. (1994, No. 2). Sustainable development at the village level in Bali, Indonesia. Human Ecology, 22, 189-211.

Mohr, L. (1995). Impact analysis for program evaluation (2nd Ed.). Thousand Oaks, CA: Sage Publications.

Morris, L. \& Fitz-Gibbon, C. (1978). How to measure program implementation. Beverly Hills, California: Sage Publications.

Morss, E. \& Gow, D. (Eds.). (1985). Implementing rural development projects: Lessons from AID and World Bank Experiences. Boulder, Colorado: Westview Press.

Moser, C. (1996). Confronting crisis: A comparative study of household responses to poverty and vulnerability in four poor urban communities. (Environmentally Sustainable Development Studies and Monographs Series No. 8). Washington, DC: The World Bank.

Murphy, J. (1995). Comments on "evaluating gender impacts," by Moser. In Picciotto, R. \& Rist, R. (Eds.), Evaluation and development: Proceedings of the 1994 World Bank conference (pp. 141-142). Washington, D. C.: World Bank.

Mussio, S. \& Smith, M. (1973). Content validity: A procedural manual. Chicago: International Personnel Management Association. 
Nyirenda, S. (1994). Assessing highly accomplished teaching: Developing a metaevaluation criteria framework for performance-assessment systems for national certification of teachers. Journal of Personnel Evaluation in Education, 8, 313-327.

Odom, S. \& Fewell, R. (1983, Winter). Program evaluation in early childhood special education: A meta-evaluation. Educational Education and Policy Analysis, 5, 445-460.

OECD Development Centre. (1989). The impact of development projects on poverty. Paris: Author.

Owens, E. \& Shaw, R. (1974). Development reconsidered. Lexington, Massachusetts: D. C. Heath.

Patton, M. (1990/1980). Qualitative evaluation and advanced research methods (2nd ed.). Newbury Park, CA: Sage Publications.

Pearse, A. (1980). Seeds of plenty, seeds of want: Social and economic implications of the green revolution. Oxford University Press.

Picciotto, R. \& Rist, R. (Eds.). (1995). Evaluation and development: Proceedings of the 1994 World Bank conference. Washington, D. C.: World Bank.

Ponzio, R., Peterson, K., Miller, J., \& Kinney, M. (1994, Fall). A program portfolio/panel review evaluation of 4-H sponsored community-based social action projects for at-risk youth. Journal of Research and Development in Education, 28, 55-65. Poverty in Sub-Saharan Africa: Issues and recommendations. (1996, October). Findings, 73. 3.

Pytlik, C. (1977). Interdisciplinary analysis of two rural development projects in Pakistan. Unpublished doctoral dissertation, Iowa State University, Ames.

Pytlik, E., Vasudevan, P., Bayles, A., \& Spitznogle, R. (1977). Assessing the literature on the benefits of external science and technology aid assistance to developing countries. Unpublished manuscript, West Virginia University, Technology Education Program, Morgantown. 
Ramashia, R. \& Rankin, S. (1995). Managing evaluation: A guide for NGO leadership. New York: Pact.

Ravallion, M. (1994). How well can method substitute for data? Five experiments in poverty analysis. The World Bank Research Observer, 11, 199-222.

Roth, M., Wiebe, K., \& Lawry, S. (1992). Land tenure and agrarian structure: Implications for technology adoption. Unpublished manuscript, University of Wisconsin Land Tenure Center, Madison.

Rugh, J. (1992/1986). Self-evaluation: Ideas for participatory evaluation of rural community development projects. Oklahoma City, Oklahoma: World Neighbors.

Rutman, L. (1980). Planning useful evaluations. Beverly Hills, CA: Sage Publications.

Ruttan, V. (1984). Models of agricultural development. In C. K. Eicher \& J. M. Staatz (Eds.), Agricultural development in the third world (pp. 38-45). Baltimore: The Johns Hopkins University Press.

Sanders, J. (1992). Impacts of new technologies in Burkino Faso and the Sudan and implications for future technology design. Paper presented at the Workshop on Social Science Research and the Collaborative Research Support Programs, University of Kentucky, Lexington.

Schmitt, N. \& Borman, W. and Associates (1993). Personnel selection in organizations. San Francisco: Jossey-Bass Publishers.

Schuurman, F. (Ed.). (1993). Beyond the impasse: New directions in development theory. London: Zed Books.

Seltzer, M. (1983). Youth, home economics, agriculture and third world development. St. Paul, Minnesota: University of Minnesota, College of Home Economics, Center for Youth Development and Research.

Shaner, W., Philipp, P., \& Schmehl, W. (1982). Farming systems research and development: Guidelines for developing countries. Boulder, Colorado: Westview Press. 
Staatz, J. \& Bernsten, R. (1992). Technology development and household food security (MSU Staff Paper 92-39). East Lansing: Michigan State University, Department of Agricultural Economics.

Stake, R. (1983/1993). Program evaluation, particularly response evaluation. In G. Madaus, M. Scriven, \& D. Stufflebeam, (Eds.), Evaluation models: Viewpoints on educational and human services evaluation (pp. 287-310). Boston: Kluwer-Nijhoff Publishing.

Stevens, R. D. (Ed.) (1977). Tradition and dynamics in small-farm agriculture: Economic studies in Asia, Africa, and Latin America. Ames, Iowa: The Iowa State University Press.

Stiglitz, J. (1996, No. 2). Some lessons from the East Asian miracle. The World Bank Research Observer, 11, 151-177.

Stout, S., Evans, A., Nassim, J., \& Raney, L. (1997). Evaluating health projects: Lessons from the literature (World Bank Discussion Paper No. 356). Washington, D. C.: The World Bank.

Stufflebeam, D. (1983/1993). The CIPP model for program evaluation. In G. Madaus, M. Scriven, \& D. Stufflebeam, (Eds.), Evaluation models: Viewpoints on

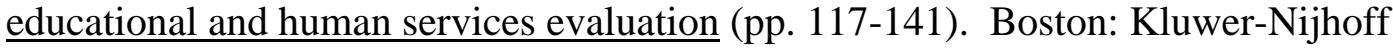
Publishing.

Suchman, E. (1967/1973). Evaluative research: Principles and practice in public

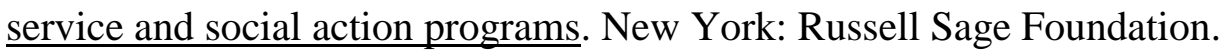

Tilburg, T. \& Haan, J. (Eds.). (1995). Controlling development: Systems of monitoring and Evaluation and management information for project planning in development countries. Tilburg, Netherlands: Tilburg University Press.

United Nations Educational, Scientific and Cultural Organization (1984). Project evaluation: Problems of methodology. Paris: Author. 
United States Agency for International Development Center for Development Information and Evaluation (1996, Number 3). Tips (USAID Publication No. PN-ABY207). Roslynn, VA: Author.

Upton, M. \& Dixon, J. M. (Eds.) (1994). Methods of micro-level analysis for agricultural programmes and policies: A guideline for policy analysts. Rome: Food and Agriculture Organization of the United Nations.

Valadez, J. \& M. Bamberger (Eds.) (1994). Monitoring and evaluating social programs in developing countries: A handbook for policymakers, managers, and researchers. Washington D. C.: The World Bank.

Volti, R. (1995). Society and technological change. New York: St. Martin's Press.

Winburne, J. (Ed.). (1962). A dictionary of agricultural and allied terminology. Michigan State University Press.

Wolf, E. C. (1986). Worldwatch paper 73: Beyond the green revolution: New approaches for third world agriculture. Washington: Worldwatch Institute.

World Bank (1994). World Development Report, 1994. New York: Author. 


\section{Appendix A}

\section{Content Analysis Data Collection Instrument}

1. Prjct ID

4. Prjet Country

6. Prjct Type

2. Prjct Dates

3. Prjct Budget $\$$

5. Prjct Region

8. Was the project evaluated? Yes No (If no, go to next project)

9. Evaluation ID Date 10. Evaluation ID Date

11. Evaluation ID Date 12. Evaluation ID Date

13. Evaluation type: (check all that apply)

\begin{tabular}{|c|l|l|l|}
\hline & \multicolumn{1}{|c|}{ Interim } & \multicolumn{1}{c|}{ Final } & Impact \\
\hline Informal & $(13.1)$ & $(132)$ & $(133)$ \\
\hline Formal & $(13.4)$ & $(135)$ & $(13.6)$ \\
\hline
\end{tabular}

14.1. Were all affected stakeholders identified and included in project goals and objectives? Yes No Not indicated

14.2. If no, which groups were left out?

14.3. Were all affected stakeholders input sought and included in the evaluation? Yes No __ Not Indicated

14.4. If no, which stakeholders were left out?

15. Were all project objectives evaluated? Yes __ No __ If no, explain:

16. Were unexpected positive or negative outcomes assessed? Yes __ No __ If yes, give examples: 
17. Evaluation items:

\begin{tabular}{|l|l|l|}
\hline \multicolumn{1}{|c|}{ Item } & Yes & No \\
\hline 17.1. Were economic or efficiency indicators evaluated? & & \\
\hline 17.2. Was the planned project process evaluated? & & \\
\hline 17.3. Was the actual project process evaluated? & & \\
\hline 17.4. Were the purpose and procedures for the evaluation indicated? & & \\
\hline
\end{tabular}

17.5. Notes or observations from above items:

18. Were there socioeconomic impacts included in the project objectives and goals? Yes __ No ___ If yes, list:

Socioeconomic impacts:

\begin{tabular}{|l|l|l|}
\hline \multicolumn{1}{|c|}{ Item } & Yes & No \\
\hline $\begin{array}{l}\text { 19. Were socioeconomic impacts evaluated? (if no, go to next } \\
\text { project) }\end{array}$ & & \\
\hline $\begin{array}{l}\text { 19.1. Were changes in income and/or living standards evaluated? } \\
\text { 19.2. Were changes in the nutritional status of households in the } \\
\text { project area evaluated? }\end{array}$ & & \\
\hline $\begin{array}{l}\text { 19.3. Was target group participation evaluated? } \\
\text { 19.4. Were groups identified who benefited from the project? }\end{array}$ & & \\
\hline $\begin{array}{l}\text { 19.5. Were groups identified who did not benefit or were harmed by } \\
\text { the project? }\end{array}$ & & \\
\hline $\begin{array}{l}\text { 19.6. Was gender equity evaluated? } \\
\text { 19.7 Was the project's effect on the environment evaluated? }\end{array}$ & & \\
\hline $\begin{array}{l}\text { 19.8. Was the project's continuation or sustainability evaluated? } \\
\text { 19.9. Were other socioeconomic indicators evaluated? (If yes, list } \\
\text { below) }\end{array}$ & & \\
\hline
\end{tabular}

19.10. Notes on socioeconomic impact indicators:

20. Other notes: 


\section{Appendix B}

\section{Instructions}

for

\section{Content Analysis Data Collection Instrument}

\section{General Instructions:}

In addition to analyzing the content of the available evaluations for the specific items listed below, the researcher will also record emerging themes from the reports. This might include such items as similar strengths and/or weaknesses between projects of which different evaluators make note; unusual or out of the ordinary evaluation results noted by the evaluator; or other themes not anticipated but occurring as the data is gathered.

Information needed to complete items 1- 7 is found in the database upon which the research is based. Answers to items 8-13 are either also in the database or the CD-ROM CD-DIS (A. I. D.'s Development information system prepared by the Center for Development Information and Evaluation, United States Agency for International Development). Beginning with item 14.1 the researcher will note in the marginal-notes-column the approximate location within the evaluation that the evidence for recording a particular response occurs. Some examples might be: methodology section, introduction, or beginning of conclusion section. Locator notes should be as short as possible but complete enough to provide the researcher or others attempting to verify the data help in locating the information.

1. Project identification (Prjct ID) is a 7 digit number assigned to a project by USAID. Very infrequently the identification also has alpha characters or contains more than 7 digits. Examples are: 2780264 or $611 \mathrm{~K} 601$.

2. Project dates (Prjct Dates) are listed in the project description. Usually in the format: Beginning Date and Ending Date.

3. Project budget (Prjct budget) is listed in the project description.

4. Project country(s) (Prjct Country) is (are) listed in the project description.

5. Project world region (Prjct Region) is listed in the project description. 
6. Project type (Prjct Type) indicates what kind of agricultural project is being attempted. Enough information must be recorded so that typologies can be assigned after all the data has been collected. For instance, irrigation of rice and palm oil trees or mechanization, tractors to replace hand work.

7. Project status (Prjct Status) as assigned by USAID in project description. Active projects are indicated by "A"; inactive by "I"; and completed by "C".

8. Was the project evaluated? If there are no evaluations available, check "no" and go to the next project. If "yes" is checked then list evaluations completed in items 9-12. 9. List the DOCID/Order Number that identifies the evaluation report. The DOCID number is always a combination of alpha and numeric characters as in this example: PNABH-942.

10. List a second evaluation report for this project here. If data later in the report relates only to an individual evaluation, indicate which one by using superscript. For example, if the report listed in number 9 is an interim report prepared by a consultant, then a check in box 13 in the interim column and formal row should have the superscript 9 next to it. Assuming the report listed in number 10 is a final report prepared by the project contractor, a check mark in the column final and the row informal should have the superscript 10 next to it.

11. List a third evaluation report for this project here. See discussion in item 10 for further clarification regarding recording information.

12. List a fourth evaluation report for this project here. See discussion in item 10 for further clarification regarding recording information. (If the project has more than 4 evaluations, use a new evaluation sheet and continue recording for evaluation number 5, etc.)

13. Evaluation type: (Check the appropriate box for each evaluation type available) Informal evaluations are conducted by the contractor, USAID project director, or USAID country director. Formal evaluations are conducted by USAID evaluation department or contracted out to independent consultants or firms.

Interim or mid-term evaluations are conducted while the project is 
still ongoing. Final evaluations are conducted at the project's conclusion. Impact evaluations are conducted sometime after the project has ended.

14.1. Stakeholders are the different groups that might be affected by the project. These might include commercial farmers, subsistence farmers, suppliers of inputs, marketing individuals, women, children, landless workers, government workers, neighbors, and/or people in adjoining communities. All stakeholders include those groups you might logically assume would be affected by the project.

14.2. List stakeholders not included in project goals.

14.3. Does the evaluation methodology indicate that all affected stakeholders were included in the evaluation and their input reported? For a discussion of stakeholders see item 14.1.

14.4. If the answer to 14.3 is no, then indicate which stakeholders were left out.

15. Project objectives being evaluated should be indicated by the evaluator in the report. Sometime the project changes focus and the newer objectives may be evaluated. 16. If unexpected outcomes are noted, they should be noted plus whether or not the evaluation considered them positive or negative.

17. Evaluation items:

17.1. Economic data most often reported is an estimated rate of return (ERR). Other efficiency indicators may be increased income or cost savings due to the introduced technology. Efficiency indicators include acres planted, animals sold, miles of ditches dug, etc.

17.2. Often the planned process for conducting a project can not be followed. Does the evaluator comment on problems or changes in the planned process.

17.3. Is the actual process under which the project was conducted evaluated?

17.4. Does the evaluator indicate the purpose for the evaluation and the evaluation procedures? Was/were the purpose(s) and procedures a part of the terms of reference for the evaluation. Procedures might include surveys of project participants, interviews with some of the stakeholders, review of project 
documents, and group focus workshops. If the purpose and procedures were part of the terms of reference put the letter " $r$ " in the yes column beside the check mark.

17.5. Under notes and observations list any unusual evaluation procedures as well as most common types of procedures. Make any additional observations on economic indicators or project processes here as well.

18. Were there socioeconomic impacts included in the project objectives and goals? If yes, list. See listing for 19.1 through 19.9 for the most common type of indicators.

18.1 If the answer to 18 is yes, list socioeconomic indicator identified.

19. Were socioeconomic impacts evaluated? These might include changes in income or living standards; changes in nutritional status at the household level; the amount and/or quality of participation by the target group; whether or not everyone benefited from the project or were certain economic, religious, or ethnic groups left out; gender equity and the project's effect on women, children and the household; environmental impacts; project sustainability after USAID monetary support ends; land tenure; possible resettlement of some or all individuals in targeted area; and health related issues. (Items 19.1 through 19.7 specify specific socioeconomic impacts that Casley and Kumar (1987) or Valadez and Bamberger (1994) suggest as feasible socioeconomic indicators that might be evaluated.)

19.1. Look for changes in income or living standards being evaluated and reported.

19.2. Look for changes in nutritional status at the household level being evaluated and reported.

19.3. Look for information on target group participation being evaluated and reported.

19.4. Look for information pertaining to who benefited and who did not benefit from the project.

19.5. Look for information pertaining to individuals or groups who did not benefit from the project. 
19.6. Look for information dealing with the participation or accessibility of the project to women.

19.7. Look for information pertaining to the environmental impact of the project on the targeted area and the adjoining areas not specifically targeted.

19.8. Look for information dealing with whether or not the project will be able to continue beyond the USAID funding period.

19.9. List any other socioeconomic indicators evaluated in item 19.9.

19.10. List any other notes to explain or qualify socioeconomic impacts that were evaluated.

20. Other notes is another place to record emerging themes or other information that might explain or provide cautions in analyzing the project evaluation(s). 


\section{VITA}

\section{Education:}

Doctor of Education in Technology Education (1998)

West Virginia University

Master Science in Agriculture Economics (1973)

University of Delaware

Bachelor of Science in Agriculture (1967)

University of Arizona

\section{Employment}

Extension Associate, State Community Development Specialist,

Clemson University (1997 - present)

County Extension Director, Aiken County, South Carolina,

Clemson University Cooperative Extension Service (1977 - 1994)

Associate County Agent, Sumter County, South Carolina,

Clemson University Cooperative Extension Service (1971-1973 and 1974 - 1977)

4-H Agent, Coconino County, Arizona, University of Arizona Cooperative Extension Service (1973-1974)

Specialist Fifth Class, Preventive Medicine Specialist, United States Army (1969-1971) 